$$
\begin{aligned}
& \text { جامعـة المنصــورة } \\
& \text { كليـــة التربية }
\end{aligned}
$$

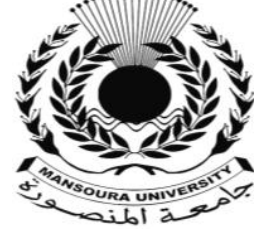

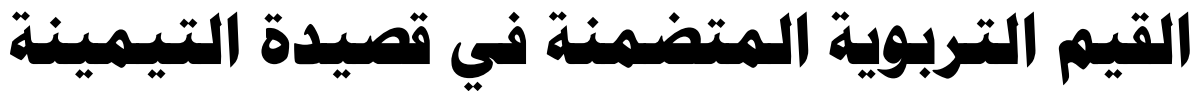 في ساطنة فمان
}

\author{
إعداد \\ د./خلفان بن ناصر بن خلفان الجابري \\ قسم الأصول والإدارة التربوية \\ كلية التربية، جامعة السلطان قابوس الإد

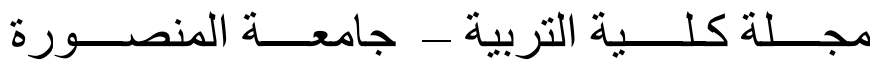

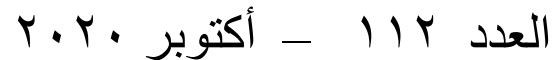




\section{القيم التربوية المتضمنة في قصيدة التيمينة في سلطنة عمان فئنة فئن}

\section{د./خلفان بن ناصر بن خلفان الجابري}

قسم الأصول و الإدارة التربوية إنتانية

كلية التربية، جامعة السلطان قابوس الادرسة

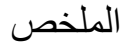

هدفت هذه الدراسة إلى الكثف عن القيم التربوية المتضهنة في النصوص الثعرية التي كانت تقال

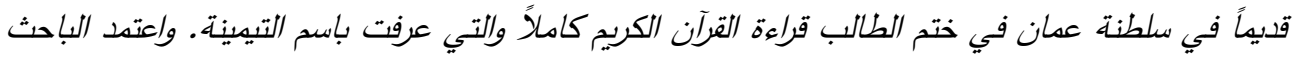
لتحقيق أهداف الدراسة على الهنهجين التاريخي في الحصول على هذه القصائد وتحقيقها، والوصفي باستخدام

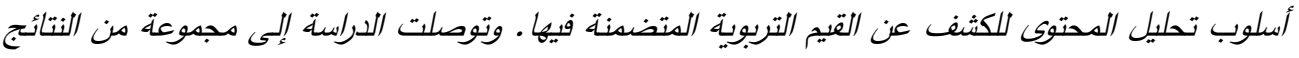

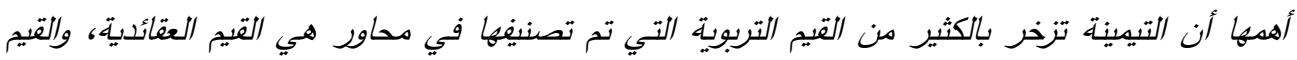

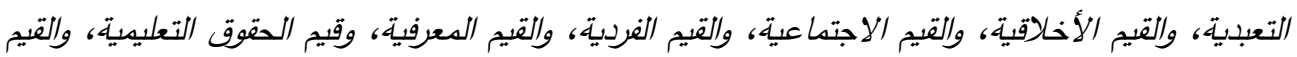

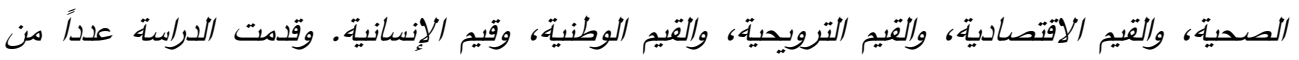

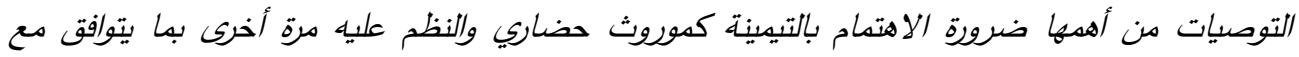

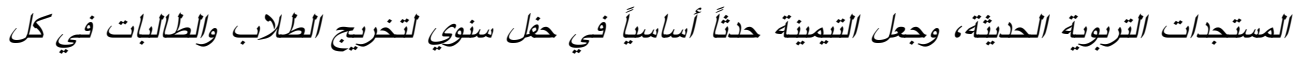

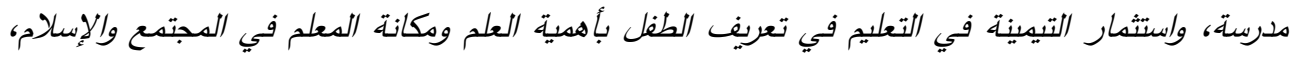

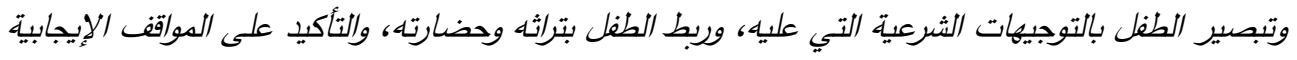

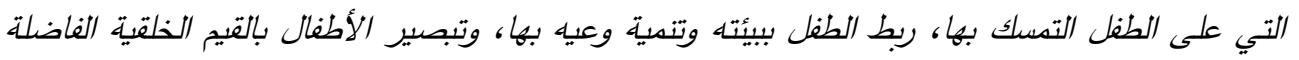

التي عليهم التحلي بها، والسلوكيات الخاطئة التي يجب عليهم اجتنابها والابتعاد عنها . الكلمات المفتاحية: القيم التربوية ، التيهينة، الشعر التعليمي. لتهي.

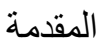

زخرت التربية الإسلامية بالعديد من المضامين التربوية التي انبثقت من تعاليم الإسلام والفكر

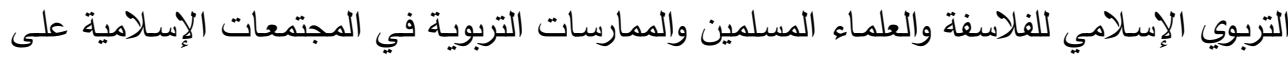
اختلاف العصور، حيث تتاسبت الأهداف التربوية في التربية الإسـلامية مـع تكوين الإنسان المسلم

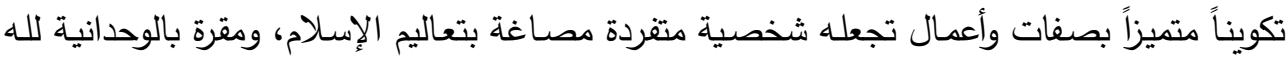
تعالى والخضوع له ومحققة للفضيلة وبلوغ السعادة في الدنيا والآخرة، ولذلك فقد شملت أهداف التربية

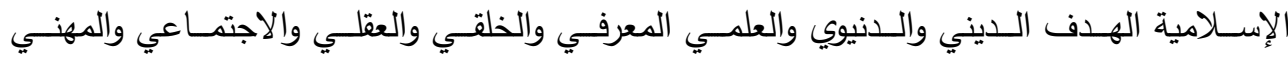

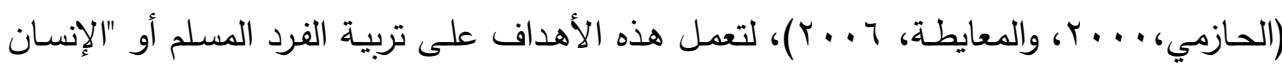


الصالح"، وإحكام تربية القدرات العقلية "وظيفة العقل"، وتربية الفرد على تعشق المثل الأعلى، وتتمية

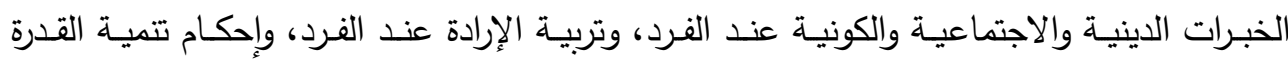
التسخيرية (القدرة على اكتثاف قوانين الخلق في الكون، والنفس واستثمارها في تطبيقات نافعة لبقاء

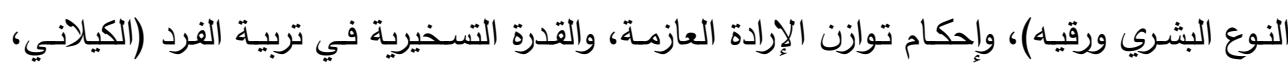
.$(r . .0$ وأسـهمت التربيـة الإسـلامية في تشكيل التعليم مـن خـلاد أهدافها التـي عملت على الوصـول

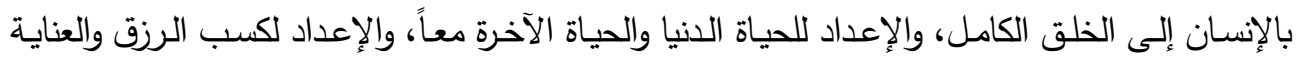
بالنواحي النفعية، وتتمية الروح العلمية لدى المتعلم، وإثباع ما لديه من ميل فطري إلى حب الإطلاه

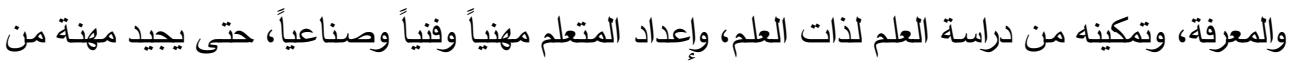
المهن أو فناً من الفنون أو صناعة من الصناعات، ويتمكن من كسب رزبه رقهه في الحياة، ويحيا حياة شريفة

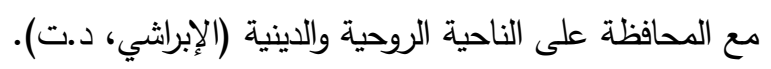

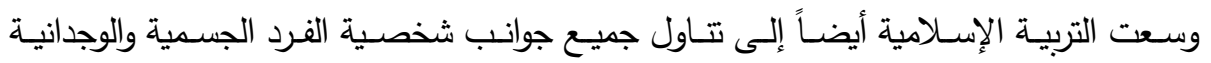

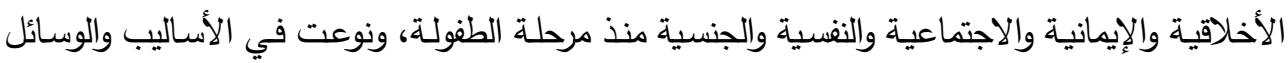

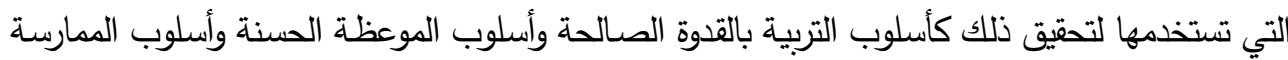
العملية وأسلوب الترغيب والترهيب مع مراعاة العستويات العقلية والخصائص العمرية لكل فئة من الفئات

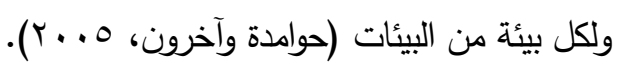

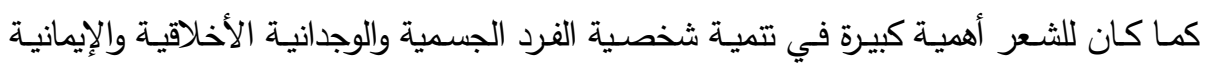
والاجتماعية والنفسية، حيث تتاول الثعر العربي بعد مجيء الإسلام مجالات أخرى كان لها الأثر الكبير في تتمية الذائقة العربية وحفظ العلوم الدينية واللغوية والنحوية والصرفية، كما استخدم الثعر في تعزيز

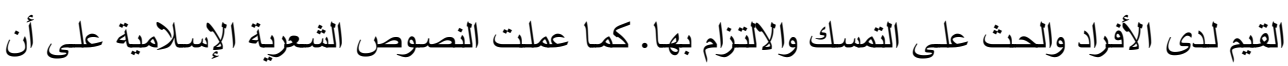
"تزكي في الطلاب الأخـاق الحميدة وتدفعهم إلى الاتصـاف بها، كما تتشط ذاكرتهم، وتتمي مواهبهر

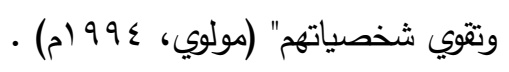
وقد أدرك العمانيون ما للشعر من أهمية وتأثير في نفوس الأفراد وقدرتهم على حفظ العلوم

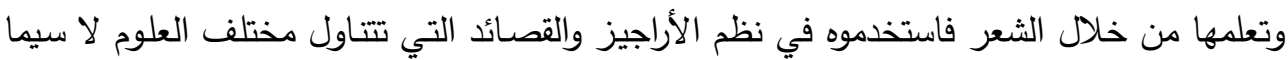

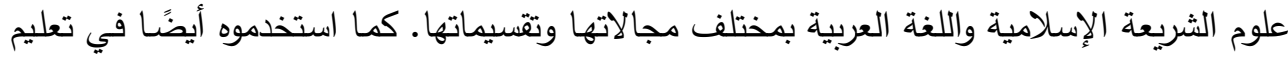
الأطفال في مدارس تحفيظ القرآن الكريم (الكتاتيب)، حيث استخدموا الثعر في أثناء فترة التعليم 
ويوم تخرج الطالب من الددرسة وختـهـ (قراءته) للقرآن الكريم كاملاً فيما عرف عند العمانيين بقصيدة التيمينة.

ولقد تضمنت هذه القصيدة العديد من القيم التربوية التي كانت تهدف إلى حث الطلاب على التصسك بها وعدم تجاهلها حتى وإن تخرج الطالب من المدرسة لتكون هذه القيم دليلاً له في حياته كلها. وعلى المؤسسات التعليمية والتربويـة دور كبير في بنـاء القيم وترجمتها إلى دلالات سلات سلوكية

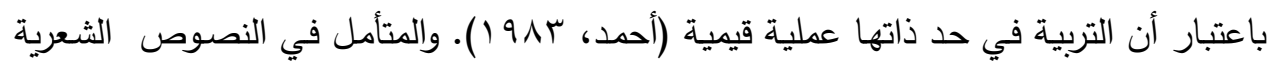

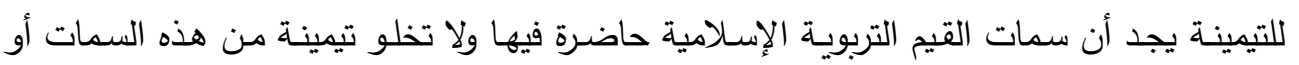

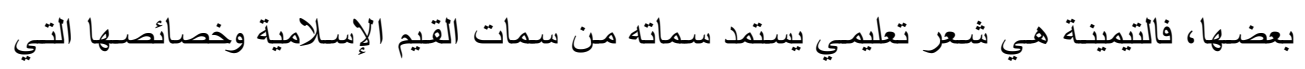
حفظت لهذه النصوص بقاءها في المجتمع العماني واستخدامها في التعليم لمئات السنين. ولما كانت التيمينة جزءًا من التراث الثقافي العماني الذي ارتبط بالعملية التعليمية في مدرسة

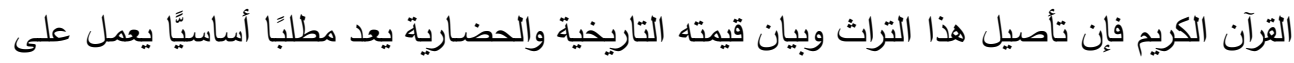
الالتفات إليه وصونه والحفظ عليه؛ ذلك أن مفهوم التأصيل مرتبط ببيان أصالة التراث وأصوله التي فئه ينتمي إليها وإبراز أهميته وقيمته الحضارية ودوره في المجتمع على مر السنين. وكلما كان التراث

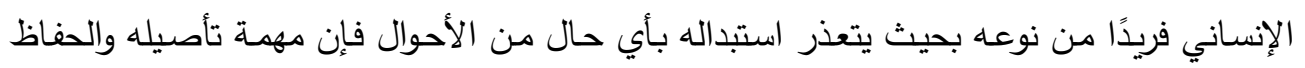

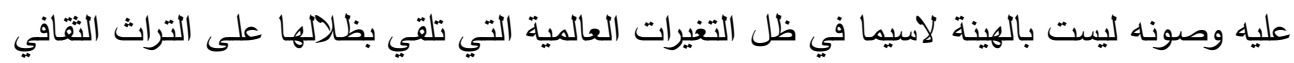

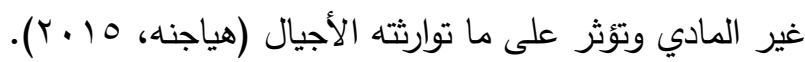
مشكلة الدر اسة:

يعد موضوع القيم التربوية من المواضيع المهمة التي درسها العديد من الباحثين والتربوين

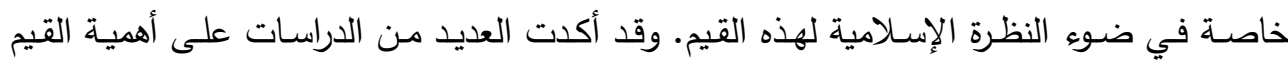

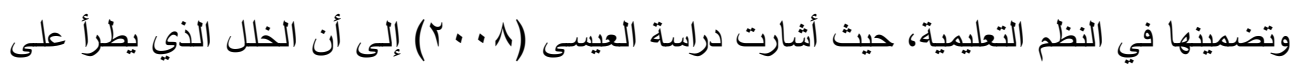
القيم الإنسانية لا يمكن علاجه إلا من خلال التربية المدرسية بما تتضمنه من مناهج ومعلمين ومواد

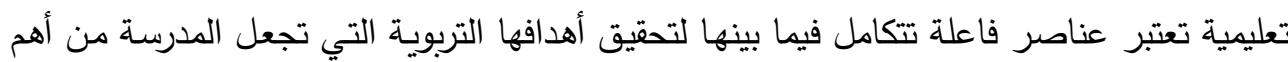
مؤسسات التربية التي تهتم بالقيم وتتميتها أسوة ببقية مؤسسات المجتمع الأخرى كالأسرة والمسجد والأندية.

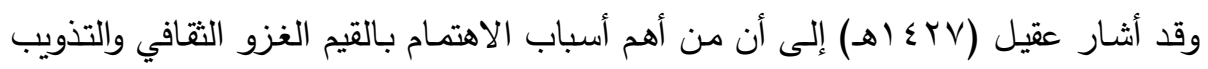

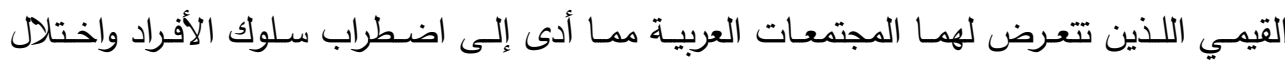
معاييرهم في هذه المجتمعات، كما أن التغيرات الاجتماعية والاقتصادية والتكنولوجية والسياسية التي التئي 
تشهدها المجتمعات فرضت واقعاً ذا معايير وقيم مختلفة لا سيما في ظل العولمة حيث تتطلب من

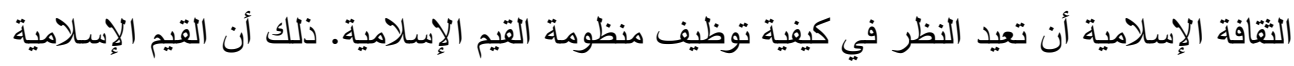

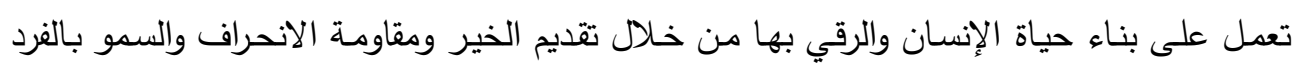
فوق الماديات المحسوسة والارتفاع به من مستوى الحيوانية إلى مستوى الإنسانية المتزنة التي تنظم

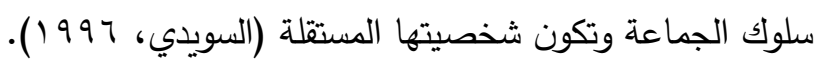

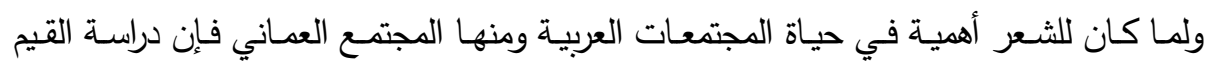

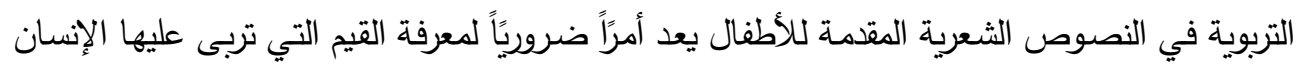

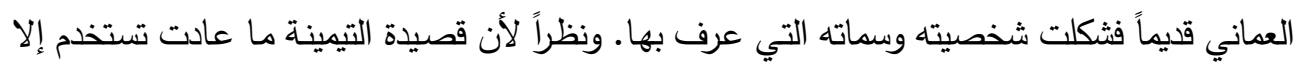
في مناسبات وحدود ضيقة جداً على الرغم من أن أجزاء بسيطة منها أدخلت في المنهج المدرسي المقرد

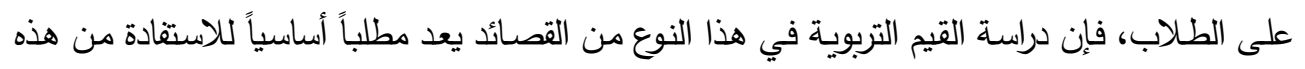

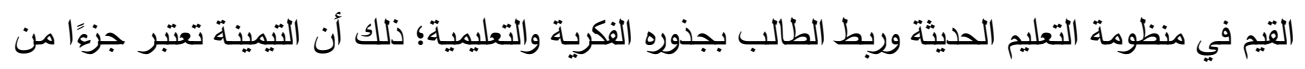
التراث الثقافي العماني الذي ارتبط بالعملية التعليمية في مدرسة القرآن الكريم.

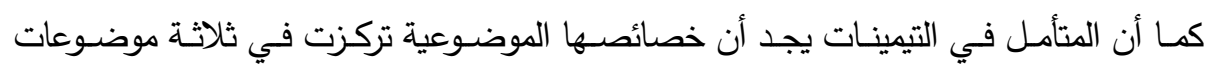
رئيسية هي الموضوعات الدينية كالإيمان بالله عز وجل وكتبه ورسله واليوم الآخر والجنة والنار والمديح

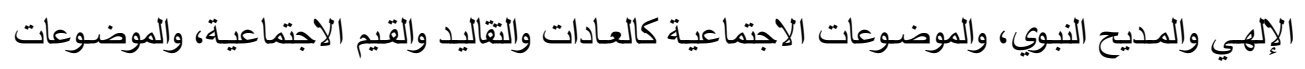
التعليمية كتعلم القرآن الكريم والحديث الثريف وعلوم الثريعة والفقه واللغة العربية وحب العلم والتعليم التئي وإكرام المعلم وتثجيع الطالب والاحتفاء به.

ولما كانت التيمينات هي شعر تعليمي يستمد موضوعاته السابقة من التربية الإسلامية فقد والداء

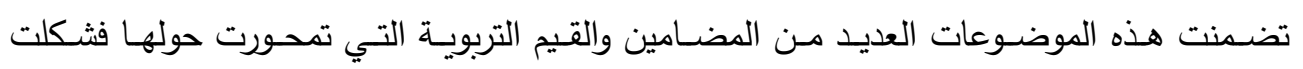
خصائصها الموضوعية. ومن هذا المنطلق فإن دراسة ما تضمنته قصيدة التيمينة من قيم تربوية يعد التحان مطلباً مهماً في سبيل تتشئة الطلاب تتشئة سليمة وربطهم بتراثهم التربوي إضـافة إلى تبيان أهمية قصيدة التيمينة في النظام التعليمي العماني قديماً ودورها في تربية الأطفال . ولذا حاولت هذه الدئة الدراسة

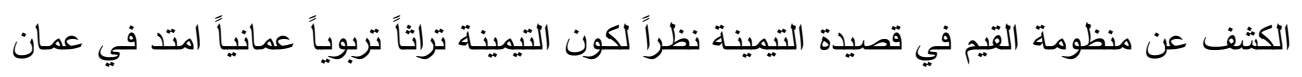
على اتساع رقعتها الجغرافية. وعليه فإن مشكلة الدراسة تتمثل في الإجابة عن السؤال الآتي: ا - ما القيم التربوية المتضمنة في قصيدة التيمينة؟

أهداف الدر اسة: تسعى الدراسة لتحقيق الأهداف التالية: 


$$
\begin{aligned}
& \text { 1- الكثف عن القيم التربوية المتضمنة في قصيدة التيمينة العمانية. }
\end{aligned}
$$

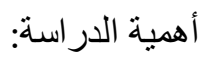

$$
\begin{aligned}
& \text { تكمن أهمية الدراسة الحالية فيما يلي: }
\end{aligned}
$$

ا - تناقش هذه الدراسة التيمينة كموروث حضاري تربوي وثقافي عماني وما لهذا الموروث من أهمية في بناء القيم وغرسها في الثخصية العمانية وتثكيلها منذ سنواتها الأولى. تونه

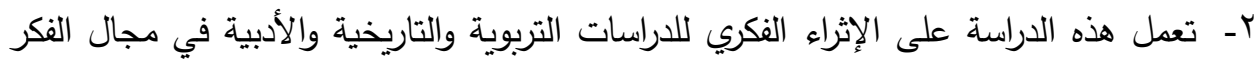
التزبوي. r- تعيد هذه الدراسة كتابة تاريخ أدب الأطفال والثعر التعليمي المنظوم في عمان وتقدم عدداً من المعلومات التاريخية العمانية. ــ - من المأمول أن تقيد هذه الدراسة القائمين على العملية التربوية في تطوير التعليم في عمان من خلال ما تقدمه من نصوص يمكن الاسترشاد بها في المناهج التعليمية المعاصرة.

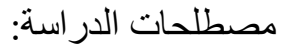
القيم التربوية تعرف بأنها "مجموعة من القوانين والمقاييس تتشأ في جماعة ما، ويتخذون منها معايير

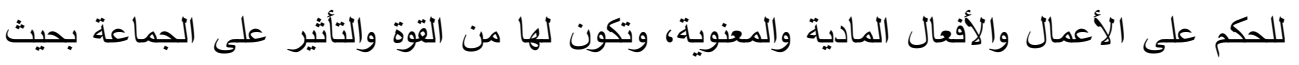
يصبح لها صفة الإلزام والضرورة والعمومية، وأي خروج عليها أو انحراف على الافئل الجاهاتها يصبح

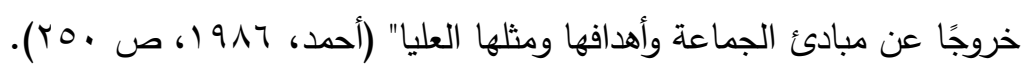
كما أنها "مفهوم يدل على مجموعة من المعايير والأحكام تتكون لدى الفرد من خلال واله

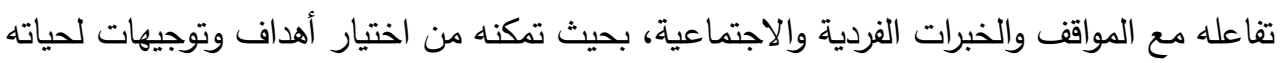

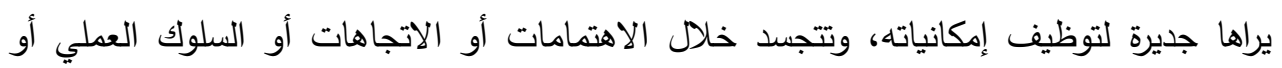

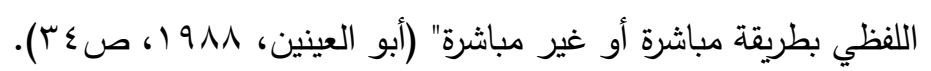
وتعرف الدراسة القيم إجرائياً بأنها مجموعة من المعايير والمبيرة والأحكام المستمدة من الإسلام والمجتمع والعادات والتقاليد والتي يراد أن تتكون لدى الطالب من خلال تفاعله مع المواقف التربوية والخبرات الفردية والاجتماعية في أثناء تأدية قصيدة التيمينة، بحيث يتم تضمين هذه المعائي لهين

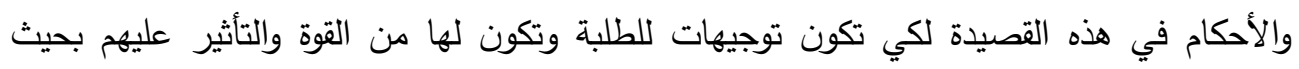

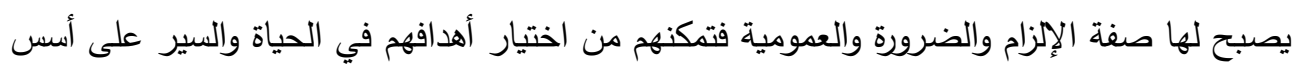


عرف الثرياني (911 (، ص ( ) التأمينة أو التيمينة بأنها "دعاء كريم اللفظ يتلى لختم القرآن الكريم، يتلوه المدرس أو أحد التلاميذ وذلك متى ختم أحد الأطفال القرآن الكريم".

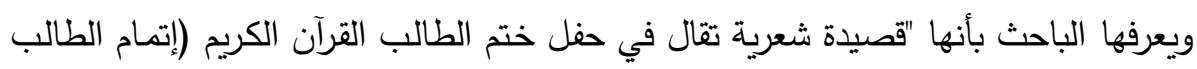

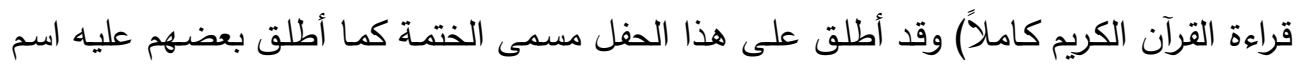

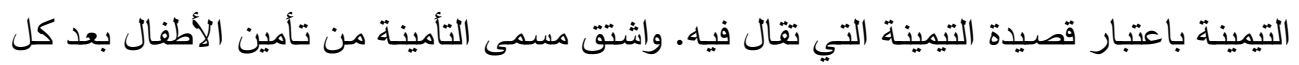

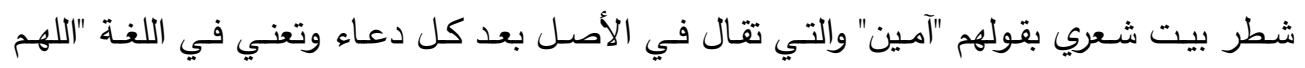
استجب". ثم تم قلب الهمزة ياء كما كانت عادة العمانيين في كثير من الكلمات فسموها تيمينة.

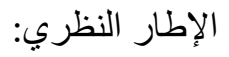

أولا: مفهوم القيم وتصنيفاتها

يعتبر موضوع القيم من المفاهيم المتداخلة في أكثر من مجال، الأمر الذي أدى إلى تعدد

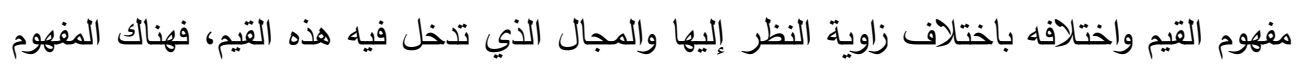

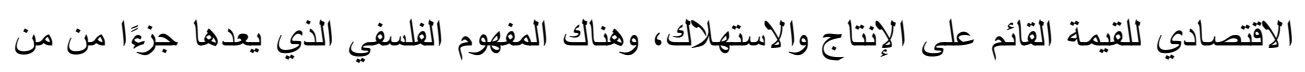
الأخلاق والفلسفة السياسية، والمفهوم اللغوي الذي ينظر لها كقيمة لغوية، والمفهوم الاجتماعي القائم

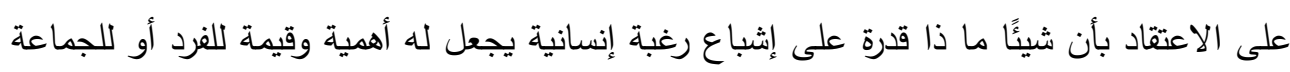

$$
\text { تكمن في العقل البشري ( طهطاوي ، } 997 \text { (1). }
$$

ولما كانت القيم تعكس الواقع الاجتماعي السائد فإن ترتيبها وتصنيفها داخل السلم القيمي يتباين أيضًا ويتتوع في البناء الواحد بتباين وتتوع الاهتمامات والمصالح الروحية والاقتصادية والاجتماعية والسياسية واختلاف تفضيلات الأفراد أنفهم وتباين أحكامهم التقديرية والواقعية لمظاهر

$$
\text { النشاط الاجتماعي (فرج، } 919 \text { (1) ). }
$$

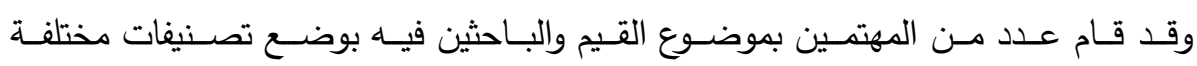

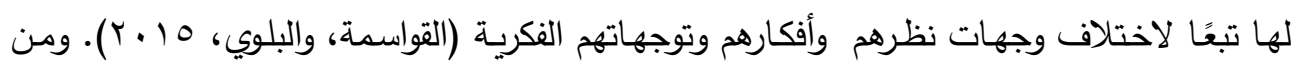

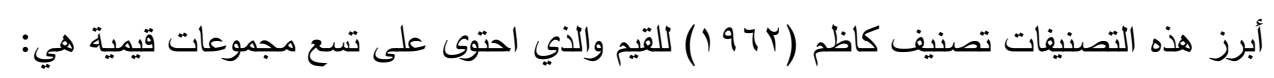
م مجموعة القيم الأخلاقية: وتشمل قيم الأخلاق والصدق والعدالة والطاعة والنقاء والطهر والدين

م مجموعة القيم الاجتماعية: وتثمل قواعد السلوك والصبر والتواضع والكرم والصداقة والخدمة

$$
\text { العامة وحب الوطن وحب الأسرة والقرابة. }
$$

م مجموعة القيم الذاتية: وتثمل القوة والحكمة والتصميم. 
م مجموعة قيم الأمن: وتثمل هدوء التثكير والاستقرار والألفة. O مجموعة القيم الجسمانية: وتثمل الصحة والنشاط والراحة.

م مجموعة القيم الترويحية: وتشمل الخبرات الجديدة والإثارة والقيم الجمالية.

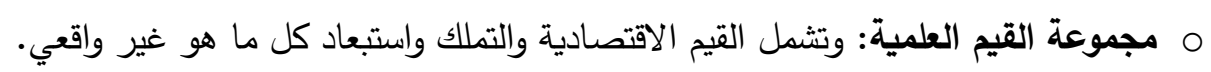
م مجموعة القيم المعرفية: وتثمل الحقائق والفهم والكتب والتعليم والتربية والرحلات العلمية.

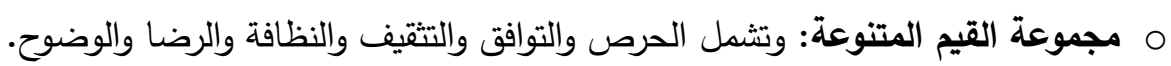

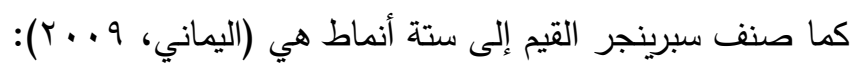

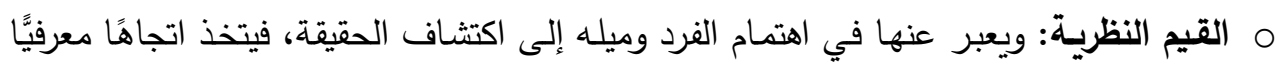

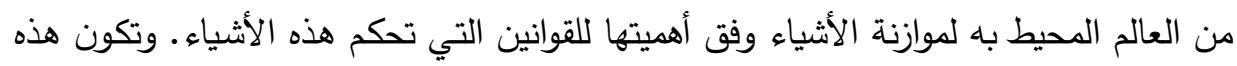
القيم عند أرباب الفكر والفلسفة.

م القيم الاقتصادية: ويقصد بها اهتمام الفرد وميله إلى ما هو نافع ماديًّا، ويكون وسيلة للحصول

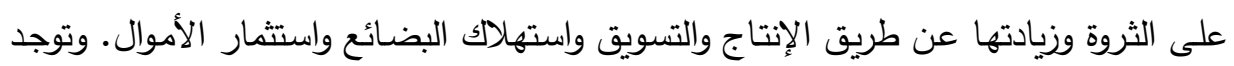
هذه القيم عند رجال الأعمال والمال.

م القيم الجماليـة: ويعبر عنها من خـلال اهتمام الفرد وميله إلى كل ما هو هو جميل من ناحية

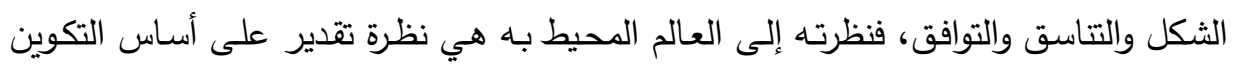
والتتسيق والتوافق الثكلي.

م القيم الاجتماعية: ويقصد بها اهتمام الفرد بالآخرين لأنه يحبهم ويسعى إلى مساعدتهم ويجد

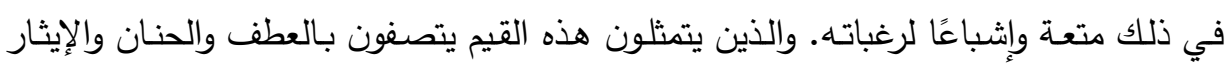
والتضحية.

م القيم السياسية: ويقصد بها اهتمام الفرد وميله للحصول على القوة، لذا فهو يحب السيطرة

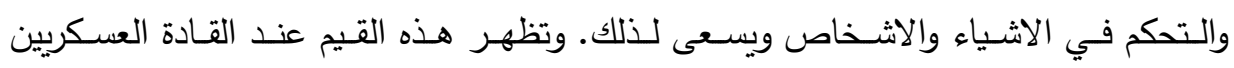
والسياسيين. م القـيم الاينيـة: تتنـاول اهتمـام الفرد في معرفة مـا وراء هذا العـالم الظـاهري وأصـل الإنسـان

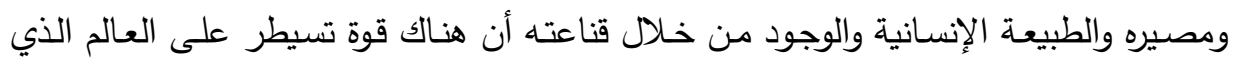
يعيش فيه. 
إضافة إلى ذلك فإن هناك العديد من التصنيفات الأخرى التي تتتاول القيم من جوانب أخرى

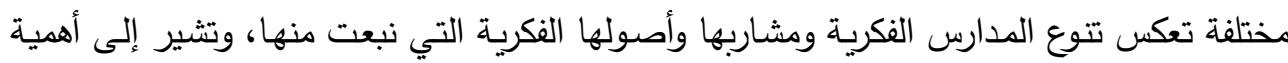

$$
\begin{aligned}
& \text { القيم في توجيه العمل التربوي ودورها في التربية (العاني، ـ ا • ب). } \\
& \text { ثانيًا: القيم والتربية }
\end{aligned}
$$

تعتبر التربية أحد أهم الوسائل الفاعلة التي تستخدمها المجتمعات في تكوين أفرادها وجعلهم قادرين على بناء هذه المجتمعات بناءً سليمًا يقوم على أسس ومعايير واضحة ومتينة تمكنهم من

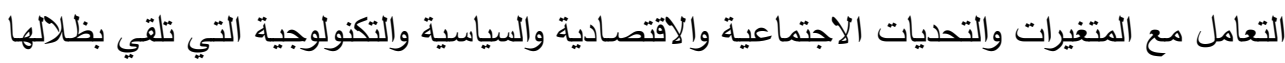
على حركة النمو في المجتمعات وتؤثر في توجهات الأفراد وقيمهم وأساليب حياتهم المعيشية. ولذا فإن التربية المثلى في المجتمعات الإنسانية، والأهداف التي تسعى لتحقيقها، والقيم المعنوية

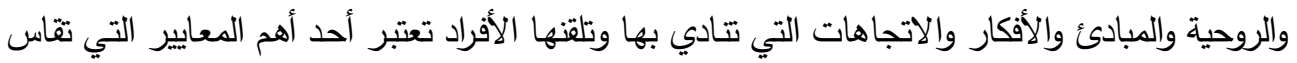
بها حضـارة الأمم (بربندي، 911 (1). ولا يمكن أن تقوم هذه التربية دون مرتكزات أساسية تبنى عليها

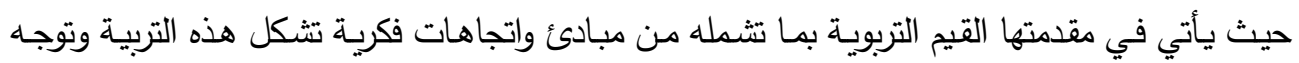
طبيعتها وتحدد مساراتها وتبين أسسها التي تقوم عليها.

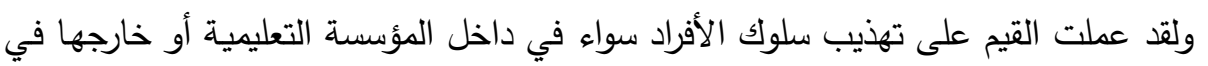

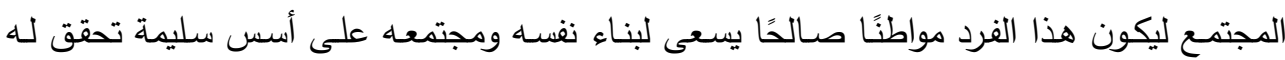

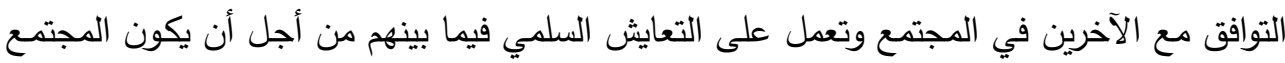

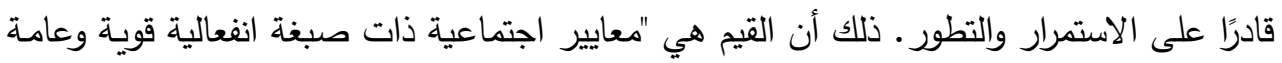

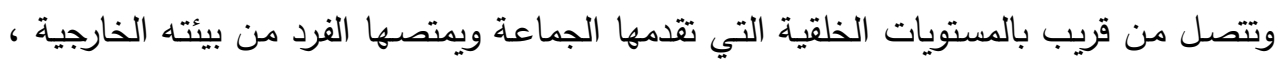

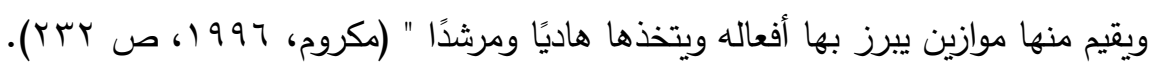

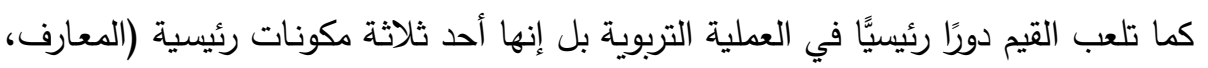

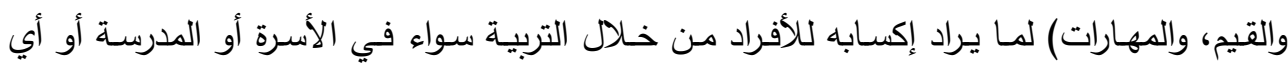
مؤسسة نظامية أو غير نظامية تقوم بأدوار تربوية. ولقد بينت العديد من الدراسات أهمية القيم في

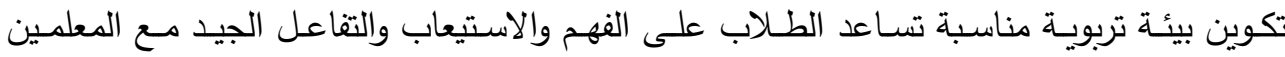

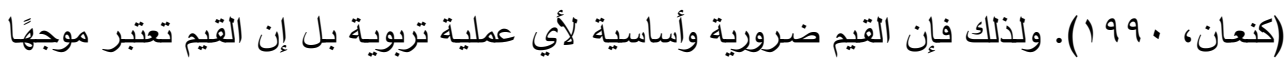

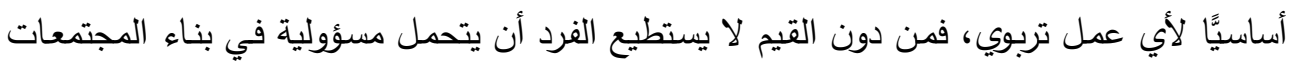

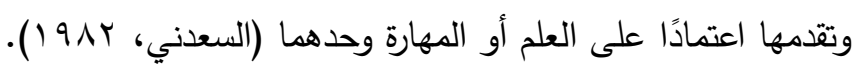


كما يؤكد التربويون على أن القيم هي معايير موجهة لحياة الفرد وسلوكه، فهي الأساس

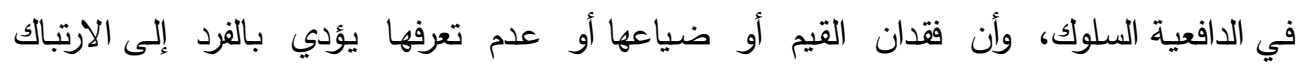

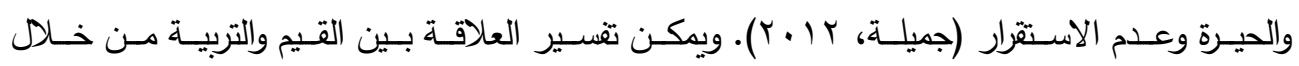

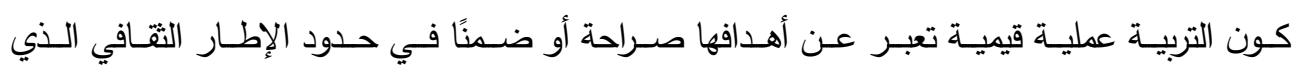
تعيش فيه التربية وتسعى من خلاله إلى بناء القيم في المجالات الخلقية والنفسية والاجتماعية ( أحمد،

كمـا تتجلى العلاقـة بين القيم والتربيـة في أن القيم تحتل مكانًا رئيسيًّا في توجيـه العملية

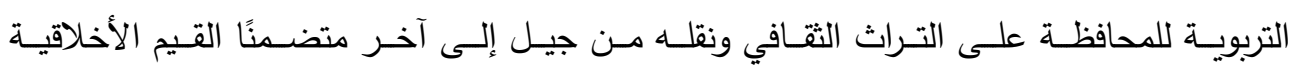

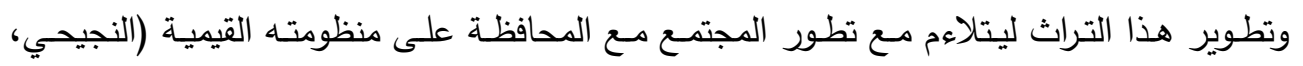

ولذلك فإن العلاقة الوثيقة بين التربية والقيم تقتضي من التربية أن تركز من الناحية القيمية

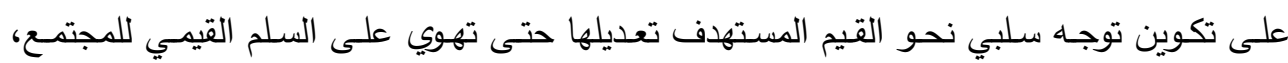
وتكوين توجه إيجابي نحو القيم المستهدفة، إضافة إلى العناية بالتوجه نحو القيم القديمة التي لم تفقد تهدي

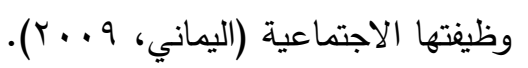
ولا يمكن لأي توجه أو ممارسة تربوية تحقيق النجاح المرجو منها في غياب مراعاتها للقيم

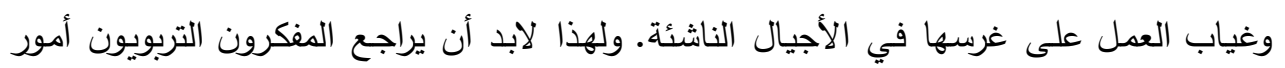
التربية وخاصة فيما يتعلق بمجال القيم لأن فقدان التربية للقيم التي تبنى عليها الثخصية يقود حتمًا

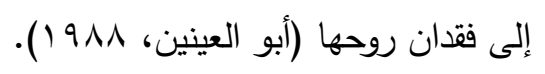

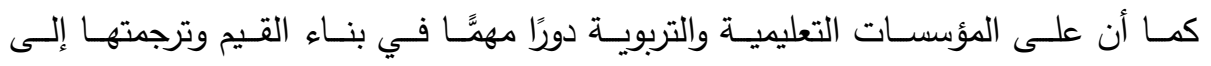

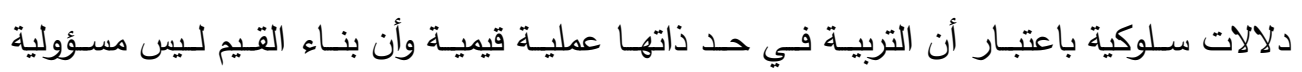

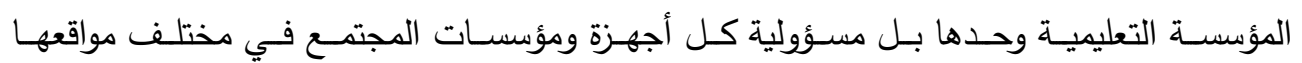

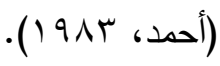


ثالثًا: سمات القيم التربوية في ضوء الفكر الإسلامي وتصنيفاتها إن التربية الإسلامية بما تحمله من فكر وقيم تربوية لتقدم الثكل المثالي للتربية والمبني على صلى التهي

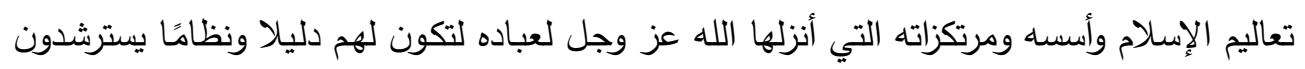
به في مختلف جوانب حياتهم على اختلاف الأمكنة والأزمنة.

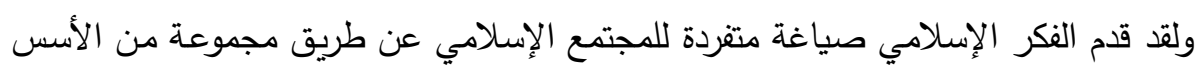

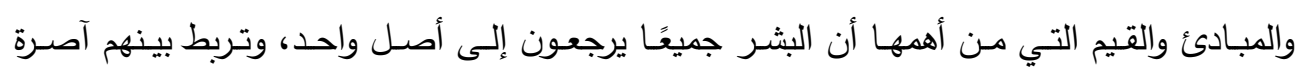

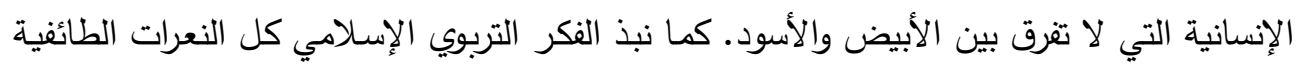

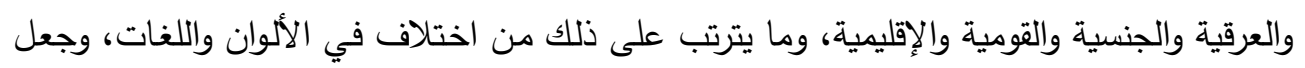
الأفضلية في ذلك للتقوى والعمل الصالح. ويقوم المجتمع الإسـلامي في الفكر الإسـلامي على عقيدة ينبع منها خلق، ويصونه نظام، وهذه الثلاث مجتمعة متضامنة متتاسقة تعمل على تربية المجتمع وتطهيره وصيانته، فتميز المسلم

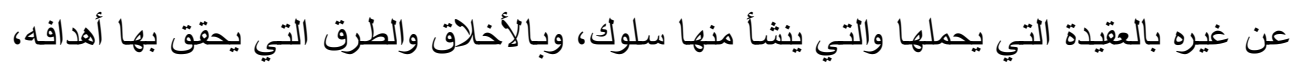

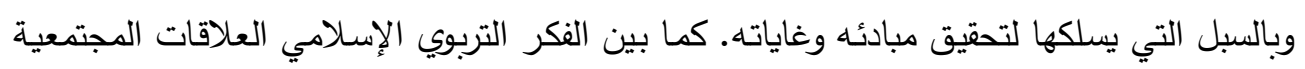

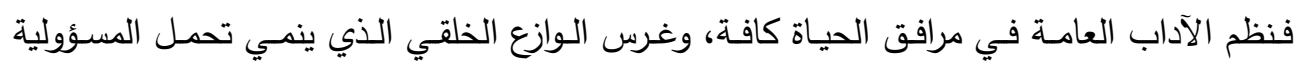

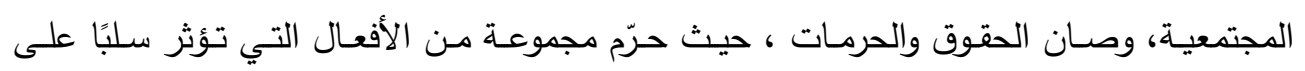

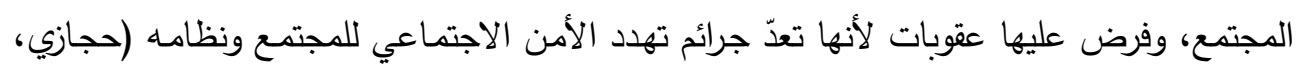

وقد شكلت خصائص الفكر الإسـلامي مجتمعة خصائص التعليم الإسلامي التقليدي فجعلته

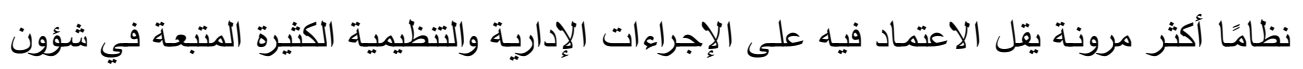
الطلاب والمعروفة في النظم الأخرى، إضافة إلى الاعتماد على تلقي العلم على يد أهله من الأساتذة الأنة

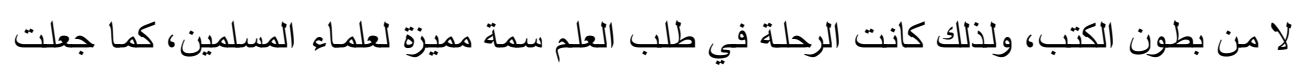

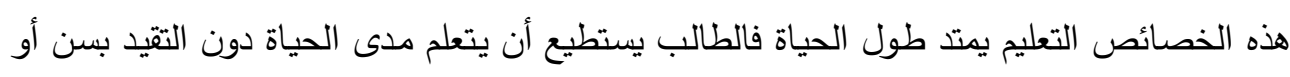

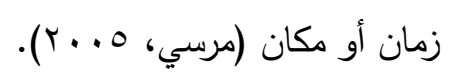
كما شكلت هذه الخصائص منظومة القيم الإسـلامية بما هي عليه من مبادىء وقواعد

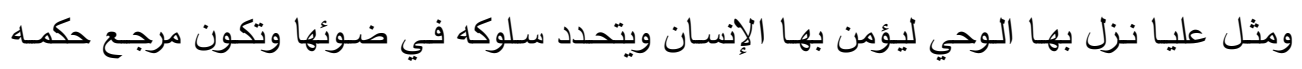

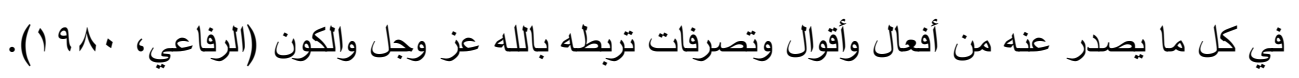


وقد تعددت الدراسات التي تتاولت سمات القيم الإسلامية بالدرس والتحليل بتعدد المنظور الذي

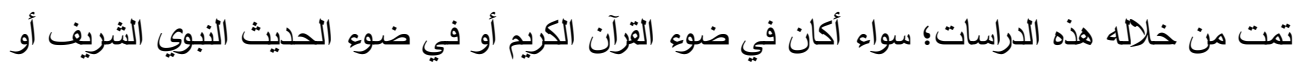

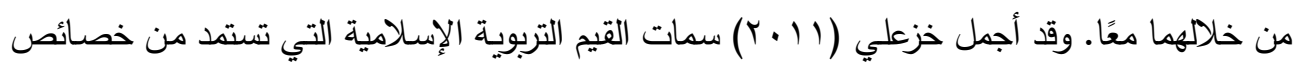

$$
\text { الفكر الإسلامي وسماته في الآتي: }
$$

م الربانية: وهي من أعظم مزايا القيم الإسـلامية على الإطلاق، وذلك أن الوحي الإلهي هو

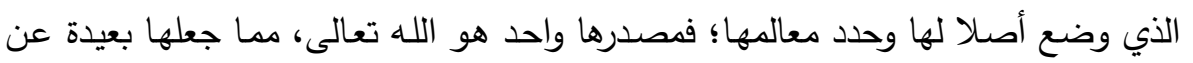

$$
\text { تعدد المصادر وتثتتها الذي يسبب تعارضها. }
$$

م عصمة القيم: هي قيم معصومة، لانبثاقها من القرآن الكريم والسنة النبوية الثريفة، فكلاهما

$$
\text { مرده الوحي. }
$$

م الخلود: فالقيم خالدة بخلود الإسلام الذي هو استمرار بقائها ما دامت البشرية مستمرة.

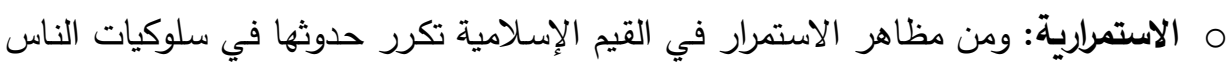

$$
\text { حتى تستقر في النفس. }
$$

م العالمية: لا يختلف اثنان أن العدل حسن والظلم سيء، وأن الصدق جميل والكذب قبيح،

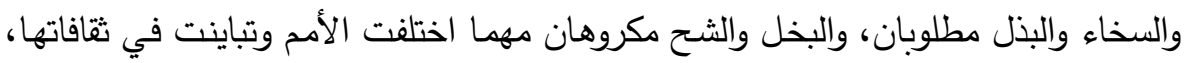

فتلك القيم وأضدادها قيم عالمية هي أصل الفطرة التي جاء بها الإسلام العالمي. م الإنسانية: هدفت الثريعة الإسلامية إلى تكريم الإنسان والإنسانية ولذا فإن القيم المنبثقة من الإنساء

$$
\text { هذه الثريعة تحمل خصائصها الإنسانية. }
$$

م الوضوح: ويدل على ذلك وصف القرآن الكريم، وهو مصدرها الأول بأنه كتاب مبين ونور

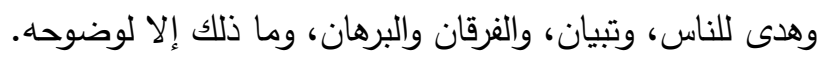

م الثمول: لم تدع القيم التربوية الإسلامية جانبًا من جوانب الإنسانية على اختلاف مجالاتها لإنها

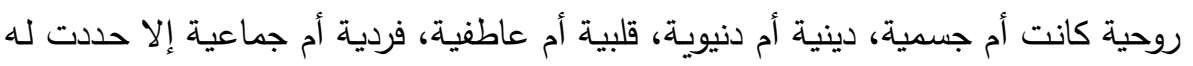

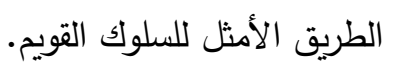

م الوسطية: وهو الجمع بين الثيء ومقابله بلا غلو من دون إفراط ولا تفريط، ومن ذلك الكئ

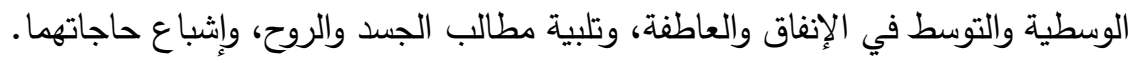

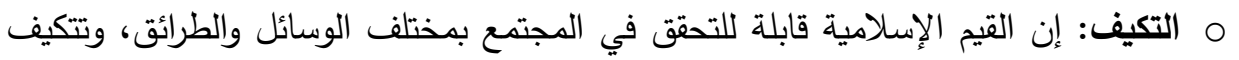
مع مختلف الأحوال والأزمان والأمصار دون أن يؤثر ذلك في جوهرها، فالعدل يتحقق في المجتمع عبر مؤسسات مختلفة قد توجدها الدولة بحسب حاجتها وعلى قدر إمكاناتها؛ فالمهم 
أن يتحقق العدل في مختلف مظاهر الحياة العامة داخل الأسرة وفي الأسواق وفي المنظمات والهيئات وغير ذلك بصور شتى وبوسائل مختلفة. م المرونة: لقد راعت القيم التزبوية الإسلامية الطاقة المحدودة التي جبلت جبلت عليها الطبيعة الإنسانية، فاعترفت بضعفه، وبحاجاته المادية والنفسية.

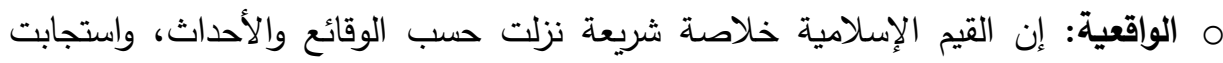

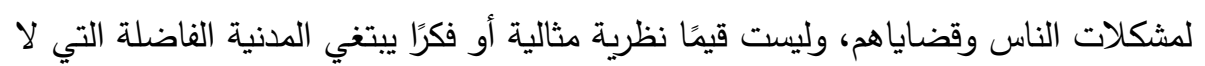

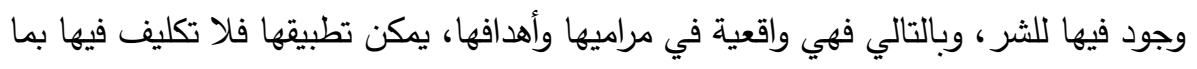
لا يطاق، ولا تغرق في المثالية التي تقعد بالناس عن الامتثال، فالعبادات والأخلاق كلها واقعية. م الاتساق: تمتاز الشريعة الإسلامية بالاتساق بشكل يجعل من بعضها أساسًا وقوة تساعد على تلى

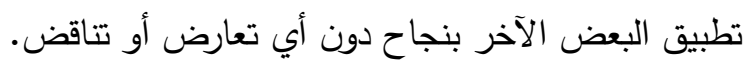

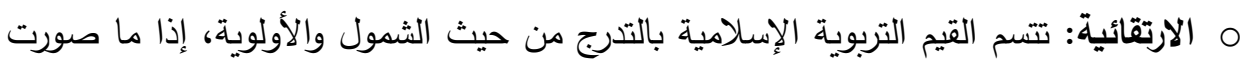

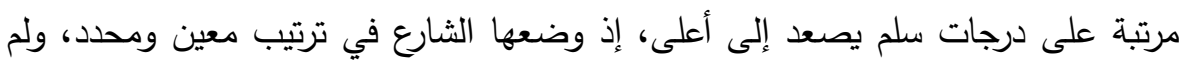
يترك للأفراد الخيار في ترتيبها أو التعديل في نسقها، وهذا مدعاة إلى توحيد الأمة؛ ليصبح التتاسق والانسجام واضحًا فيما بينهم. م التوازن: تلاحظ هذه الخاصية بوضوح تام في كل جزئيات الشريعة الإسلامية، والتي قامت

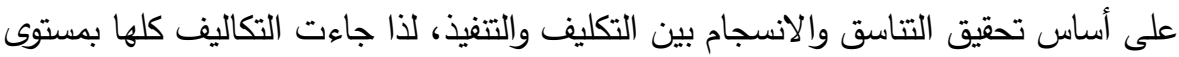
قدرات الإنسان وإمكانياته ومتوازنة معها. كما تتضمن هذه الخاصية أيضًا تحقيق القيم التربوية الإسلامية للتوازن بين جانبي الروح والجسد. م الكمال: تتصف النظرة الإسلامية للقيم التربوية بالكمال، فهي نابعة من المذهبية الكاملة، لأن مصدرها هو الله عز وجل العالم بخبايا الإنسان والكون وسننه.

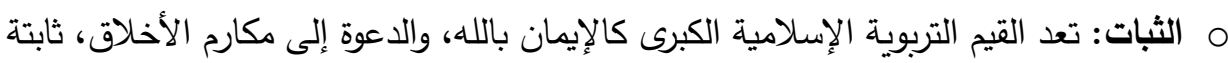
لا تخضع للأزمان ولا للبيئات، وهناك قيم ترتبط بعادات الناس وتقاليدهم إذ تختلف قيم الإسليه

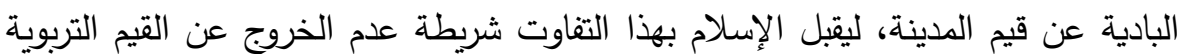

$$
\text { الكبرى التي شرعها الحق تعالى. }
$$

م الإيجابية: ويقصد بها أن يتعدى الخير للآخرين، فلا يكفي أن يكون الإنسان صالحًا في

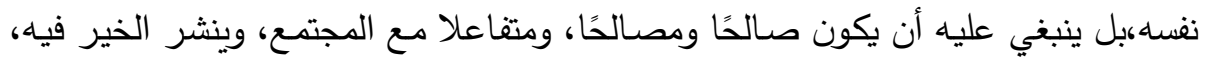


ويعلم الجاهل ويرشد الضال. وتأتي هذه الإيجابية للقيم من إيجابية الإسلام نفسه؛ فهو دين إيجابي مؤثر ليس من طبيعته الانكماش والانعزال والسلبية.

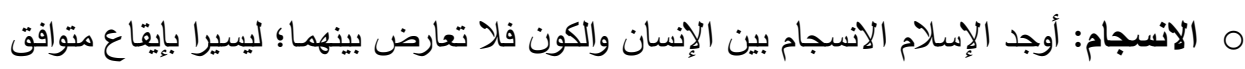

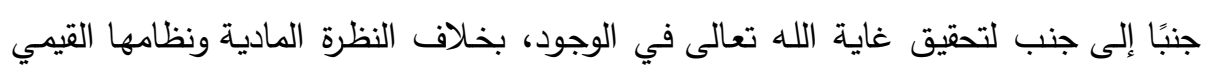

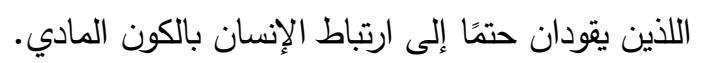
م التكامل: فالتفكر في ملكوت السموات والأرض وآيات الله في الكون جزء مكمل للعبادة. م الحفاظ على نظام الحياة: تهدف القيم التزبوية الإسلامية إلى الحفاظ على سلامة وسوية النظام في الحياة دون إحداث الفساد فيه. م تربية الوازع الداخلي: تسعى القيم التربوية الإسلامية إلى تربية الوازع الداخلي في الإنسان من غير رقابة خارجية.

م ارتباط القيم بالدين: ترتبط القيم التربوية بالدين ارتباطًا وثيقًا فلا انفصال بينهما.

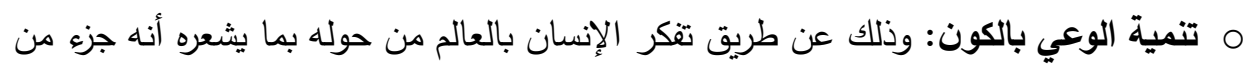
هذا الكون الدقيق. م تنمية الوعي بالدور الحضاري للإنسـان: من خلال تحديد مسؤولياته في الحياة، واستثمار خبراته بالعلم والعمل، وتوظيف طاقاته في مجالات الحق والخير والجمال والعدل.

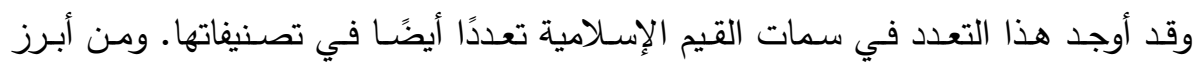

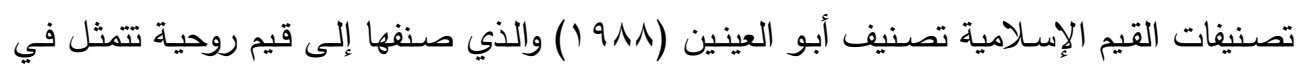

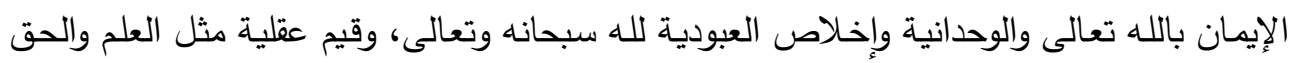
في حياة الإنسان، وقيم أخلاقية مثل التقوى ومصدر هذه القيم من عن عند الله تعالى، وقيم نفسية الإنية

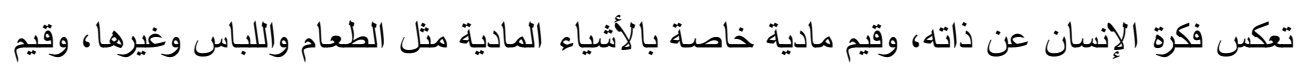

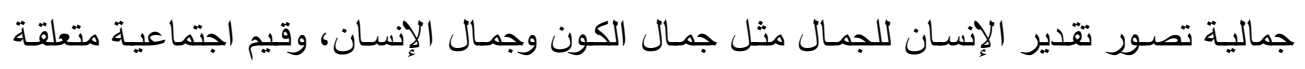

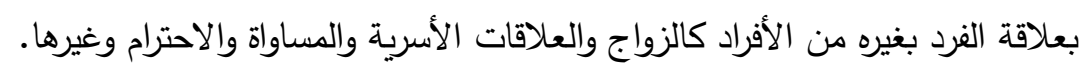

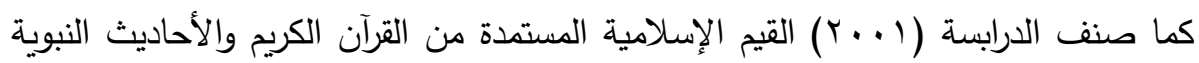
الثريفة إلى تسعة أقسام هي: م القيم العقائدية: وتثمل الإيمان بالله تعالى وملائكته وكتبه ورسله واليوم الآخر والقضاء والقدر خيره وشره. O القيم التعبدية: وتشمل الصلاة، الصوم، الزكاة، الحج، الجهاد وغيرها. 
م القيم الأخلاقية: وتثمل آداب المعاملة، الصدق، الكرم، التسامح، الأمانة وغيرها. م القيم الاجتماعية: وتثمل التكافل، صلة الرحم، التعاون، حب الناس، الصداقة التة وغيرها.

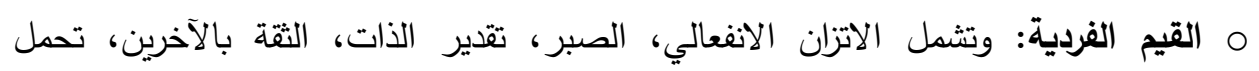
المسؤولية وغيرها.

م القيم المعرفية: وتضم طلب العلم، نشر العلم، آداب الحوار، تقدير العقل، المنهجية العلمية وغيرها.

م القيم السياسية: وتثمل الحكم بما أنزل الله عز وجل، العدل، المساواة، الحرية، الديمقراطية

$$
\text { والثورى وغيرها. }
$$

م القيم الاقتصادية: وتضم الكسب الحلال، التتمية، تقدير العمل، إتقان العمل، التخطيط، المحافظة على المال العام. م القيم الترويحية والبيئية: وتضم تذوق الفنون، الترويح البدني والهوايات الهادفة، الاهتمام بالبيئة. رابعاً: تضمين القيم في الثعر التعليمي تكمن قيمة شعر الأطفال في موضوعاته التي يتتاولها بما تحويه من روائع الحكمة وجيد الأمثلة واتجاهات أدبية واجتماعية تعمل على غرس العواطف النبيلة والأخلاق الفاضلة في نفس الطفل وتتمية وجدانه وتدفعه إلى حب الخير والعدل والواجب وكل معاني الجمال الإنساني (قناوي، ـو 99 ()).

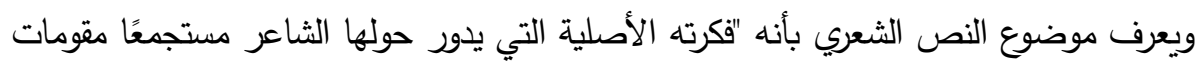
العمل الفني من ألفاظ وتراكيب وخيالات وموسيقى خارجية وداخلية عبر بناء فني لغوي مناسب لطبائع

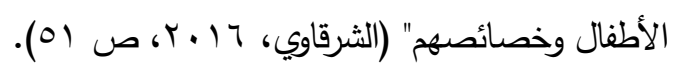
ويعتبر مضمون الأدب "العمود الفقري الذي يبعث فيه الحركة والحياة، ويجب أن يسير في خط

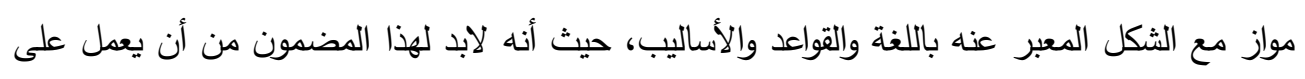

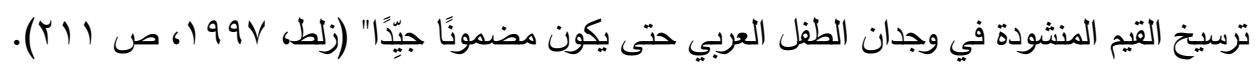

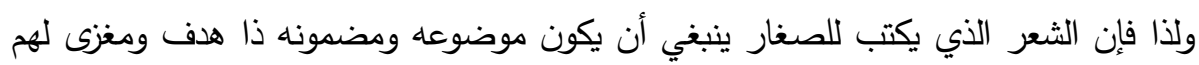

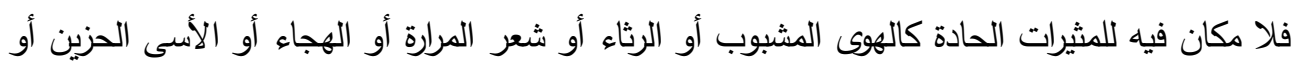
الكراهية أو غيرها من الأغراض والمواضيع الثعرية والمضامين التي لا لتتاسب مع الأطفال سنًا وفكرًا (الحديدي، 911 (1). 


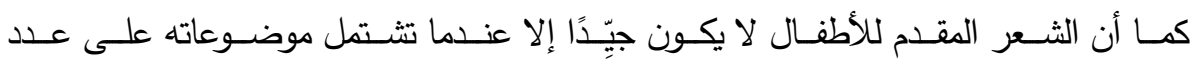

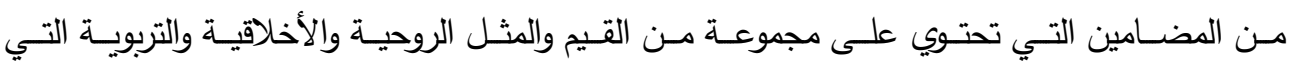
يظل بها الطفل مثاليَّا في نظر الكبار الذين يكتبون لـه الثـعر ملـونين قصـائدهم بمضــامين وألكوان

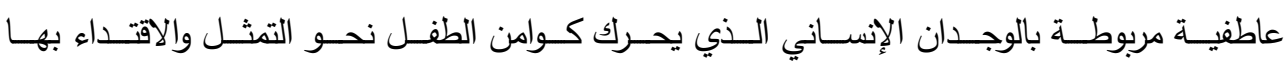

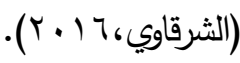

إن النصوص الثـعرية الإسـلامية تتزكي في الطلاب الأخـلاق الحميدة وتدفعهم إلى الاتصـاف بها، كما تتشط ذاكرتهم، وتتمي مواهبهم وتقوي شخصياتهم" (مولوي، ـ99 الم). كما يلعب الثنعر دورًا

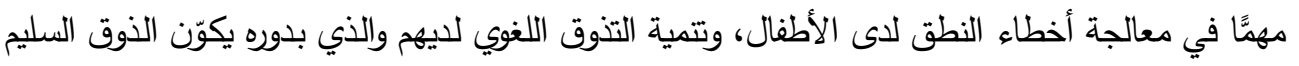
لديهم ويزيد من استمتاعهم باللغة واستخدامها قراءة وكتابة، ويكسبهم معايير ذوقية سليمة تنعكس إيجابًا

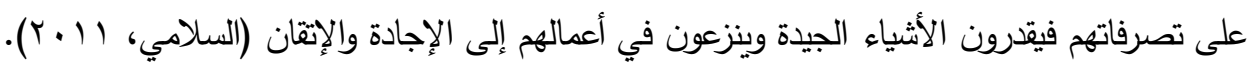

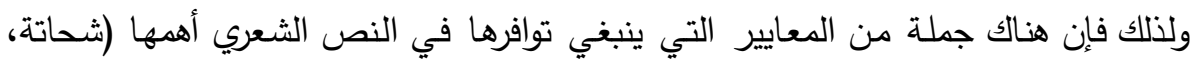

م أن يكـون الـص الثـعري المختـار صـدى لتجـارب مـرت بالأطفـال وفـي اسـطاعتهم أن

\section{يفهمومها.}

م أن يكون النص الثعري ذا إيقاع موسيقي مؤثر يجذب شوق الأطفال ويثير مشاعرهم. O أن يتصل بمناسبات عامة قومية أو وطنية أو دينية.

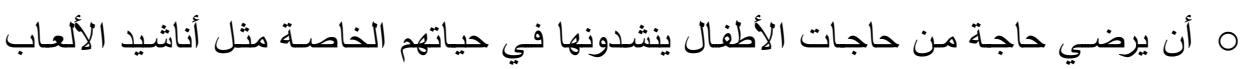

$$
\text { والرحلات والحفلات. }
$$

م أن يساعد التلاميذ في إحياء المواسم والاحتفالات كالأعياد والمناسبات. م أن يكون النص مما يثير حماسة الطلاب ويجذب انتباههم. O أن يكون من الأوزان السهلة والبحور القصيرة كالأراجيز •

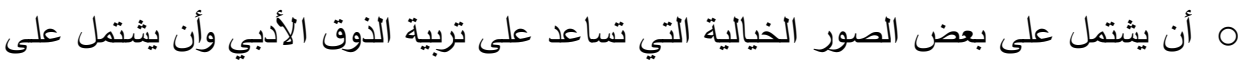

$$
\text { المعاني السامية التي تدعو لتهذيب الخلق. }
$$

م أن يكون وثيق الصلة بخلفية الأطفال وبعصرهم، والعلاقات الأسرية بين الطفل وأخيه، وبينها.

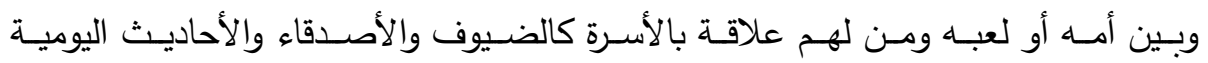

$$
\text { والحيوانات والطيور · وله }
$$


م أن يتجانس اللفظ مع المعنى، أي يكون اللفظ رقيقًا في المواقف الرقيقة وأن يكون قويًَا في

$$
\text { المواقف القوية. }
$$

م أن يحمل أفكارًا وقيمًا تمد الأطفال بالتجارب والخبرات وتجعلهم أكثر إحساسًا وأن تكون تلك أكواء

$$
\text { م أن تكون لغة الشعر عربية فيتطيع الطفل أن يدركها. }
$$

م أن يتتاول النص الثعري بعض القيم الاجتماعية مثل الصدق والأمانة وحب الوطن والثعور

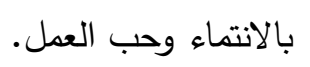

\section{خامساً: تاريخ الثعر التعليمي في عمان:}

يمتد تاريخ النظم العلمي في عمان إلى القرن الثالث الهجري حيث نظم أبو المؤثر الصلت بن

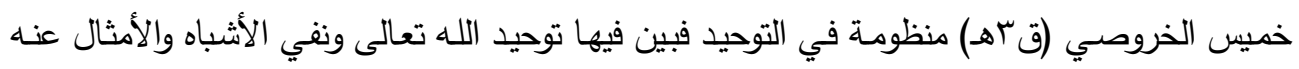
سبحانه وتعالى وأسماء الله عز وجل الحسنى وصفاته إضافة إلى رده في منظومته على المخالثين في العقيدة. وتلا ذلك العديد من المنظومات التي ازدهرت في المجتمع العماني لاسيما بعد القرن السادي ودئه الهجري عندما نظم الفقيه الثـاعر ابن النضر ديوانه الدعائم، حيث تتاولت المنظومات العمانية القرآن

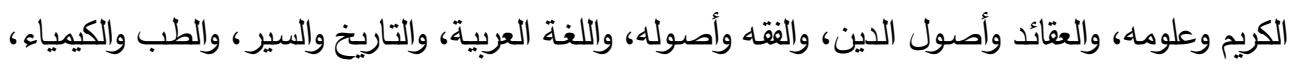

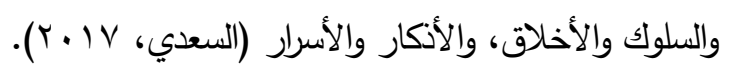

وبالنظر إلى الدراسات التي تتاولت الثعر التعليمي في عمان فقد اقتصر ذكره على المنظومات

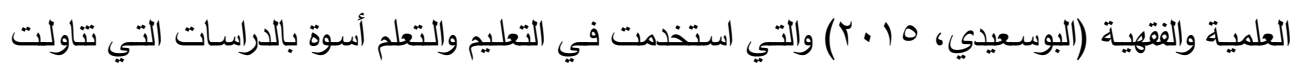

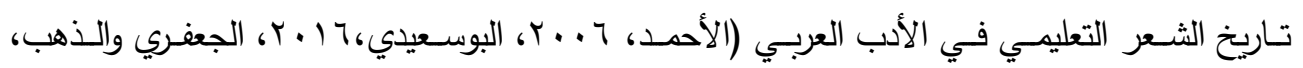

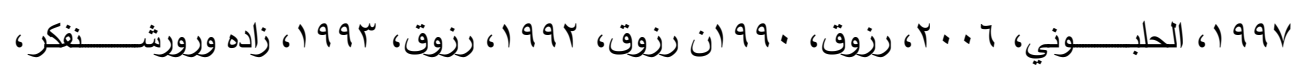

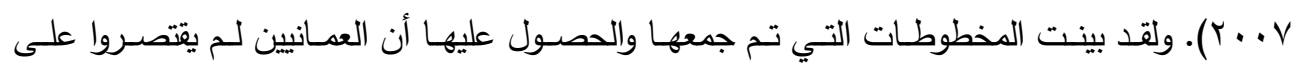
المنظومات العلمية كنوع وحيد للثعر التعليمي بل تعدوه إلى استحداث فن شعري مستقل بذاته أطلقوا

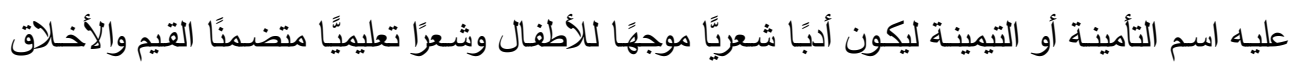
الحميدة التي على الطلاب أن يتمثلوها في سلوكهم. ثم استخدموه في الاحتفاء بالطالب الذي يختم القرآن

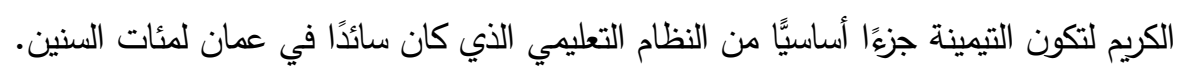

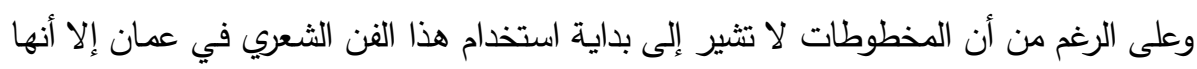

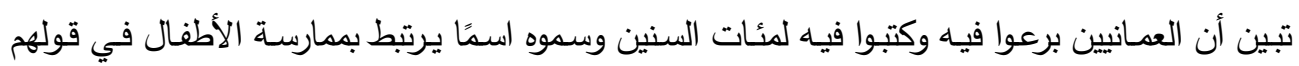
"آمين"، فكان أدبًا مكتوبًا للطفل سبق أدب الأطفال الدكتوب في العصر الحديث. ولقد ظل أغلب إنتاج 
هذا الفن مطويًّ في مخطوطاته لسنوات طويلة جدًّا ولم ير النور منه سوى بضع قصائد تم التعامل معها

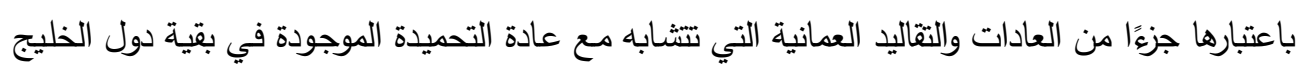
العربية فقط، من دون النظر إليه على أنه أدب للأطفال وفن شعري له سماته الخاصة التي تجعله فريدًا من نوعه، ومن دون تتبعه وتأصيله تاريخيًا وتراثتًا.

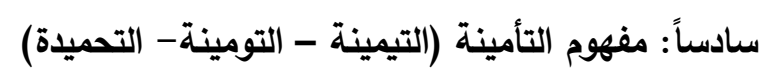
التأمينة أو التيمينة هي قصيدة شعرية تقال في حفل ختم الطالب القرآن الكريم (إتمام الطالب التبات

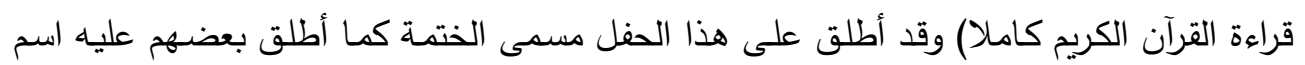

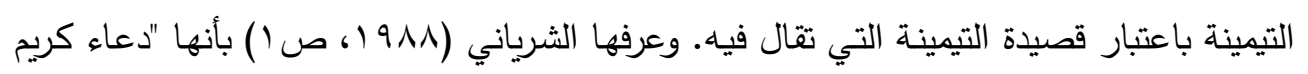
اللفظ يتلى لختم القرآن الكريم، يتلوه المدرس أو أحد التلاميذ وذلك متى ختم أحد الأطفال القرآن الكريم". وقد ورد اسم التأمينة صراحة في كثير من القصائد التي كتبت لتكون تيمينة، ومن ذلك قول

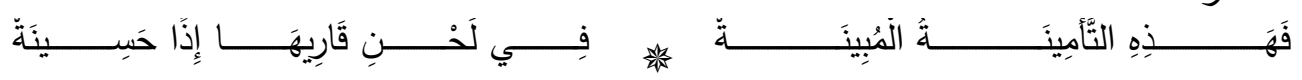
واشتق مسمى التأمينة من تأمين الأطفال بعد كل شطر بيت شعري بقولهم "آمين" والتي تقال

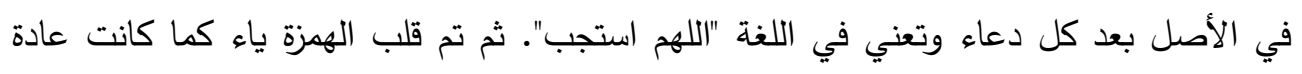

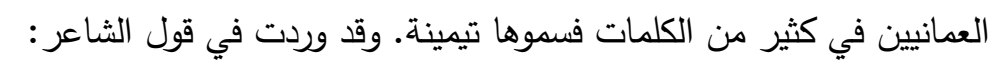

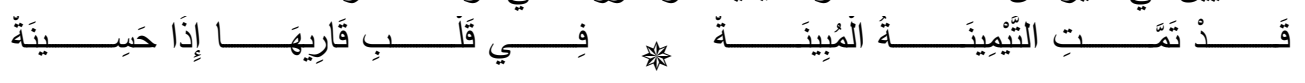
وأما مسمى "التومينة" أو "التومين" أو "الأومين" فأخذ من قول الأطفال في بعض الأماكن من

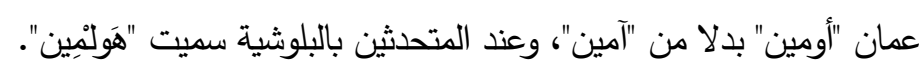

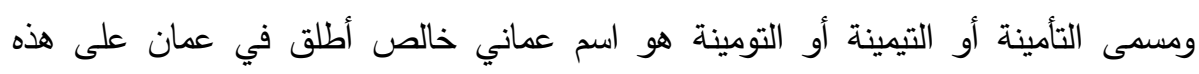
القصيدة، ثم انتقل بعد ذلك إلى بعض الدول المجاورة. ولم يرد هذا الاسم في أي معجم من معاجم اللغة

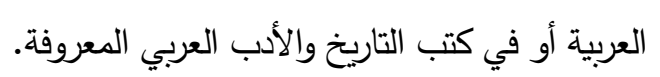
وأما مسمى "التحميدة" فمأخوذ من التحميد وهو قول "الحمد لله" في أول بيت من أبياتها وبهذا

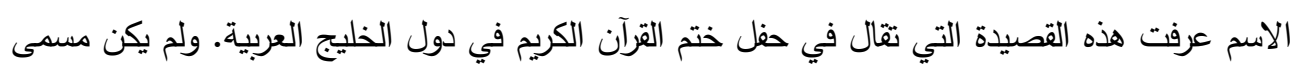

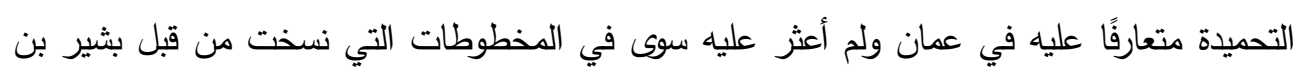

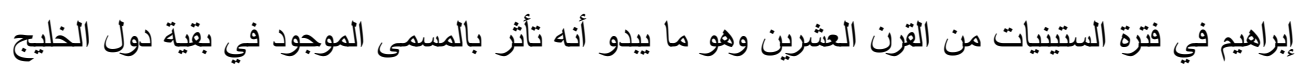
العربية. 
ومن الجدير بالذكر بأن محافظة ظفار لم تعرف مسمى التيمينة أو التحميدة على الرغم من وجود الاحتقال بختم الطالب للقرآن الكريم ووجود قصائد استخدمت كتيمينة فيها أسوة ببقية محافظات السلطنة.

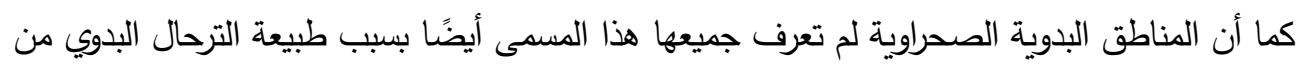

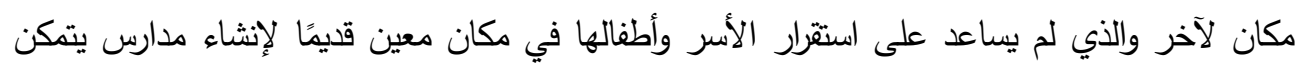

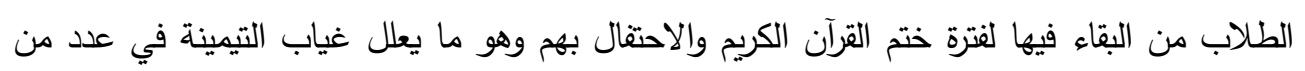
مناطق محافظة الوسطى قديمًا. لا تذكر المراجع التاريخية والأدبية والتربوية واللغوية التي تطرقت إلى التيمينة أو التحميدة أي شيء عن نشأتها سوى أنها قصيدة تقال في حفل ختم الطالب للقرآن الكريم. وفي المراجع التي تتاولت التهاتيه التعليم في دول الخليج عدا عمان فقد أشارت إلى أن ظهور التحميدة وانتشارها فيها يرجع إلى بدايات القرن العشرين الميلادي.

ومن خلال تتبعنا لمخطوطات التيمينات في عمان فان أقدم نص تم العثور عليه يؤرخ لكتابته في

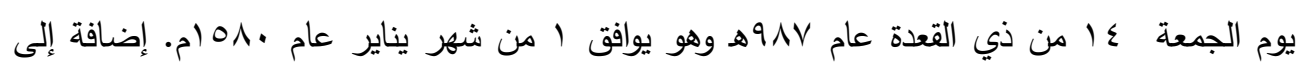

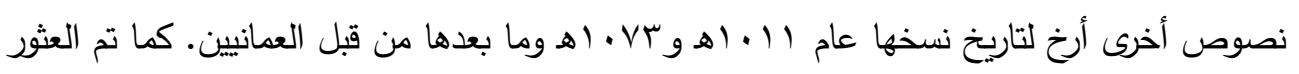

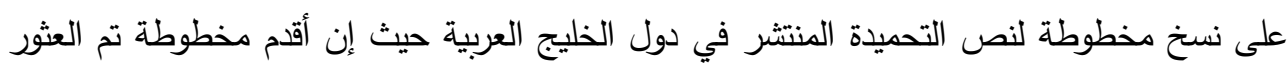

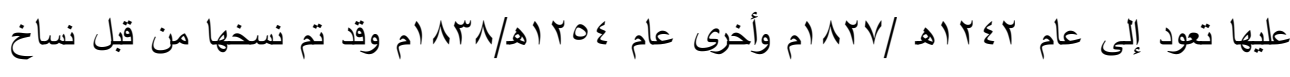

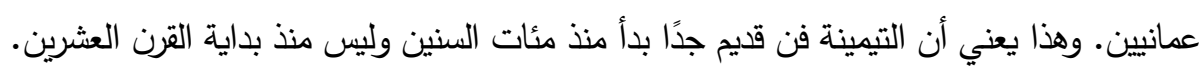

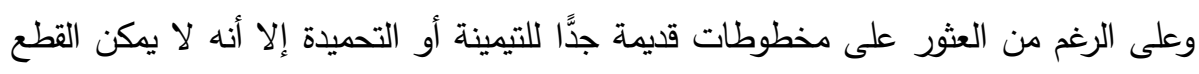
والجزم بأن هذا النوع الثعري قد بدأ في عمان؛ نظرًا إلى أن الاحتفال بالطالب الذي يختم القرآن الكريح

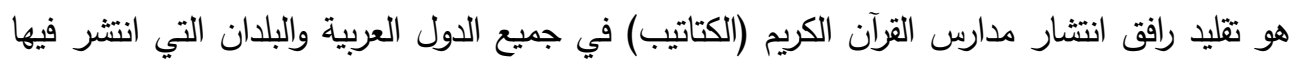

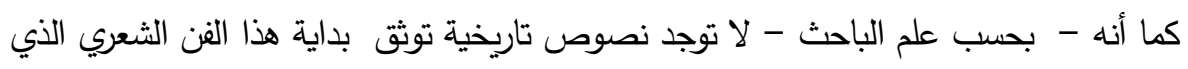

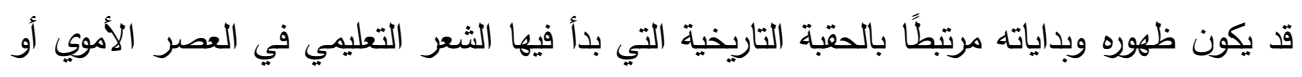

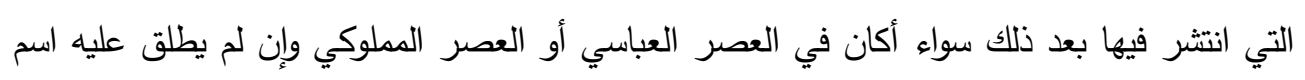
"التيمينة". ولكن ما يمكن القطع به هو أن مسمى التأمينة أو التيمينة هو مسمى عماني خالص نثأ في

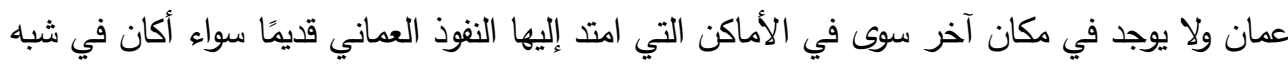
الجزيرة العربية أو في شرق أفريقيا. كما أن المراجع التاريخية والأدبية والتربوية والمعاجم اللغوية العربية - 
بحسب علم الباحث - لم تشر إلى وجود هذا المسمى أو المصطلح، أسوة بالكثير من المصطلحات

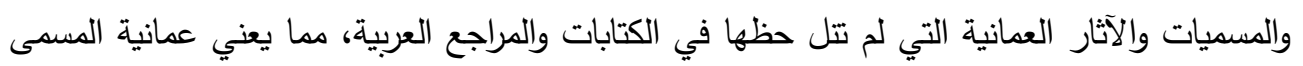
وأصالة نثأته في المجتمع العماني.

وقد حافظ العمانيون على هذا الفن الثعري وطرقوه وألفوا فيه أكثر من غيرهم وأسموه التأمينة أو

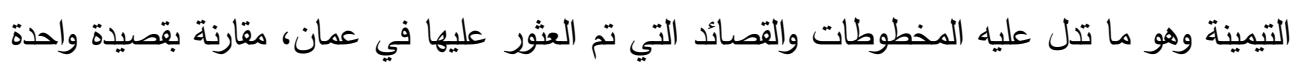
مما كتب ليكون تيمينة وبضعة مقطوعات شعرية منتشرة تم استخدامها كتيمينة في بقية دول الخليج

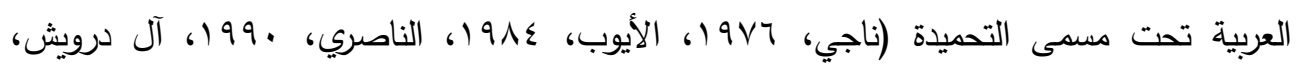

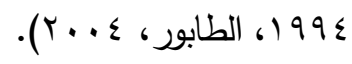

وكان آخر نص كتب كتيمينة هو في عام 9 با اه/9V0 ام لمؤلفه الفقيه علي بن صالح الثلي

حيث ظلت التيمينات بعد هذا التاريخ حتى الوقت الحالي تقال اعتمادًا على النصوص القديمة المتوارثة. وذلك راجع إلى عدة عوامل أبرزها ضياع عدد من مخطوطات التيمينات، واقتصارها على نسخ محدودة

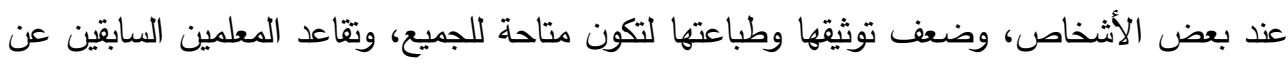

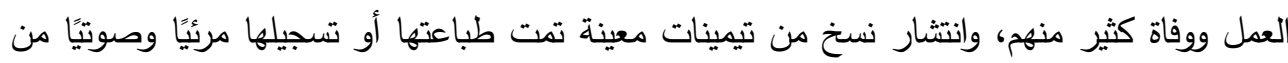

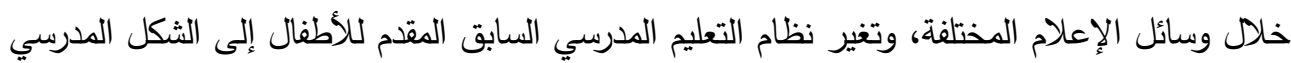
الحديث والذي ألغى احتفال التيمينة المرتبط بختم الطالب للقرآن الكريم واقتصر على إلى إيراد أجزاء بسيطة منها في المنهج المدرسي واجتهادات فردية من قبل بعض المدارس في المحافظة على التيمينة باعتبارها إحدى العادات العمانية الموروثة.

ومن الجدير بالذكر أن تجربة الذكتورة سعيدة الفارسي في كتابة شعر الأطفال عام •99 ام في

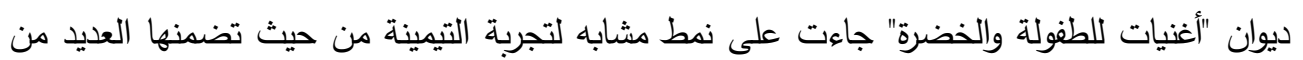

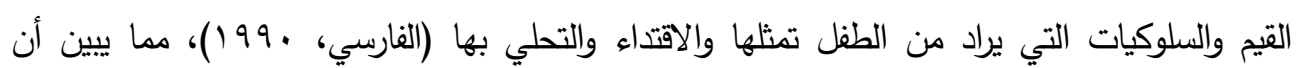
التيمينة ما هي إلا شكل سابق لأب الأطفال الحديث في عمان. سابعاً: طبيعة التيمينة تعتبر التيمينة نوعًا من أنواع الثعر وفنًا من فنونه، وهي النوع الأدبي الأكثر ارتباطًا بالتعليم

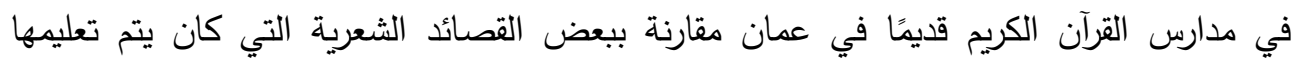

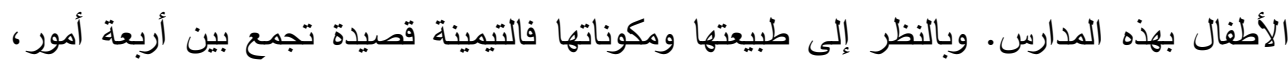


1- قصيدة من الثعر التعليمي المنظوم (المنظومات التعليمية) بما تحويه من معارف وقيم

$$
\text { وأخلاق يراد من الطالب اكتسابها والتحلي بها. }
$$

r- قصيدة من أدب الطفل (شعر الأطفال) بما تحويه من أبيات شعرية تضم معارف وقيمًا موجهة إلى الأطفال، وبما تقال فيه من مناسبة ختم الطفل للقرآن الكريم وتأديتها مع الأطفال

$$
\text { وبهم. }
$$

r- قصيدة من الثعر العربي الغنائي الوجداني بما فيها من صور وأغراض شعرية.

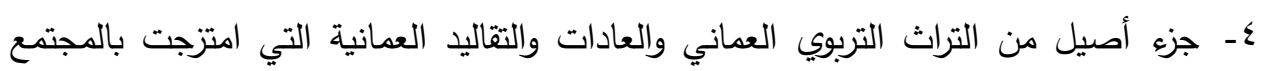

$$
\text { العماني في إطاره الكلي واستمرت معه لمئات السنين. }
$$

ثامناً: أشكال كتابة التيمينة

تتوعت أشكال القوالب التي كتبت فيها التيمينة، وهناك ثلاثة أثكال وجلت عليها التيمينة

$$
\text { وكتبت فيها هي: }
$$

أ- الطي بحيث كانت تكتب التيمينة في ورقة واحدة أو عدة أوراق تلصق معا كورقة واحدة

تطوى في هيئة أسطوانية، ويصل طول الواحدة ما بين متر إلى مترين اعتمادًا على عدد ألى

$$
\text { أبياتها. }
$$

بـ الأوراق المنفصلة بحيث كانت التيمينة في عدة أوراق منفصلة اعتمادًا على عدد أبياتها.

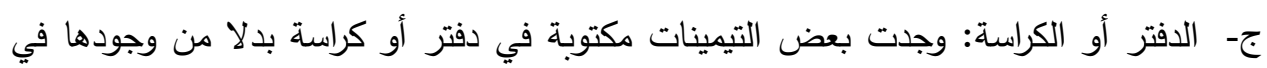

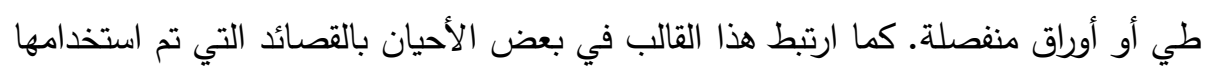

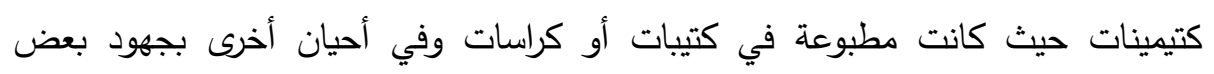
المعلمين أو النساخ الذين حاولوا جمع بعض التيمينات في مكان وان واحد.

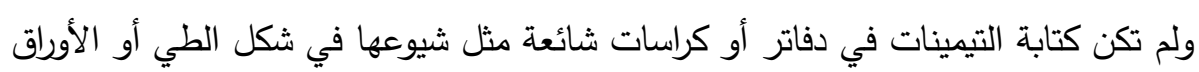
المنفصلة، وذلك قد يكون راجعًا إلى حاجة المعلمين إلى تيمينة واحدة يستخدمونها في الاحتفاء بختم

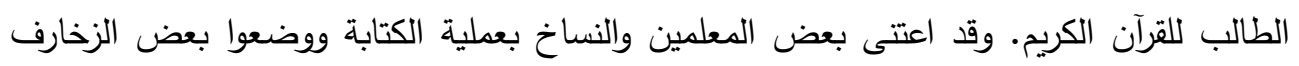

$$
\text { والنقوش في التيمينات. }
$$

تاسعاً: طريقة أداء التيمينة

نظرًا لكون التيمينة احتفاء بالطالب الخاتم للقرآن الكريم فإن طريقة تأديتها كانت قائمة على

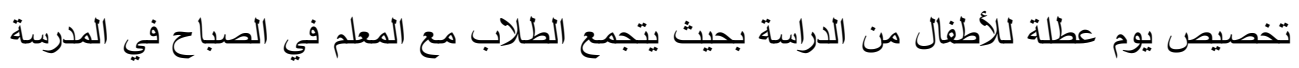

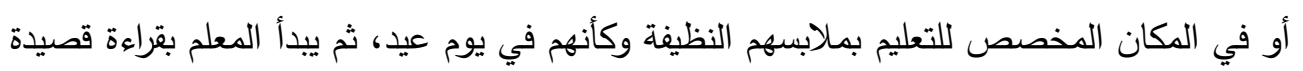


التيمينة بصوت شجي مصحوب بالتنغيم والطلاب يرددون بعد قراءة كل شطر كلمة "آمين". وقد

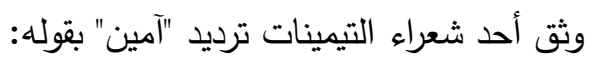

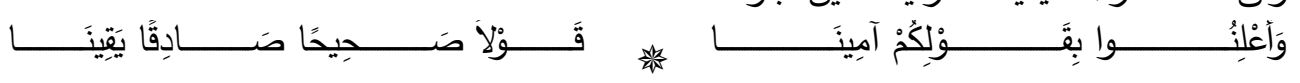

ووجد من المعلمين من كان يطلب من أكبر الطلاب سنَّا أو أكثرهم قدرة قرائية أن يقرأ

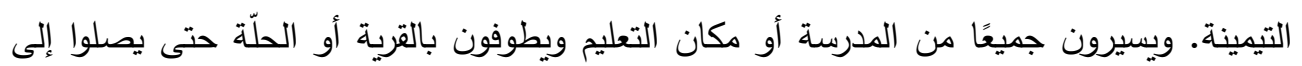

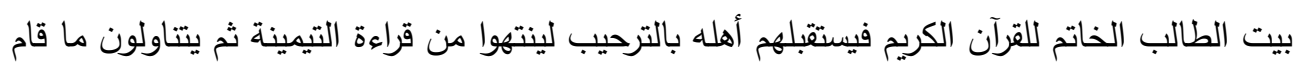

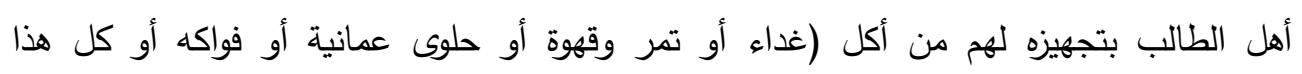
مجتمعًا) بحسب الوضع الاقتصادي لأهل الطالب. وفي ذلك يقول أحد شعراء التيمينات:

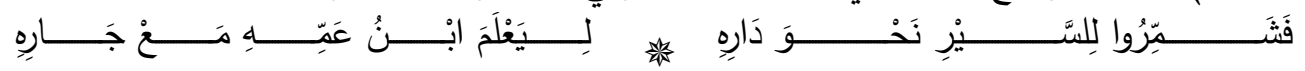

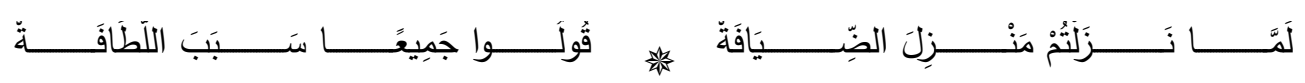

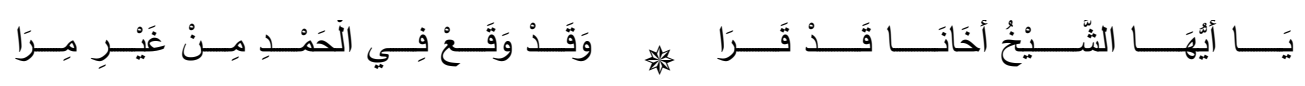

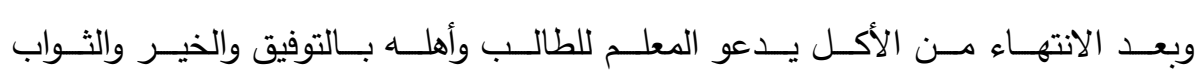

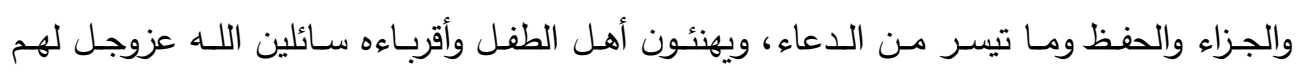

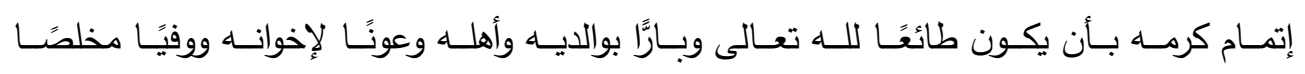

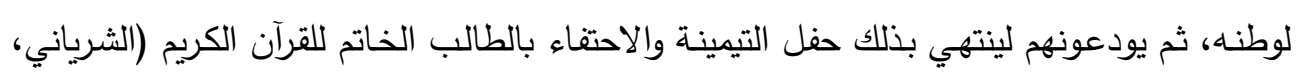

وعلى الرغم من شيوع المسير والطواف في أداء التيمينة من المدرسة إلى بيت الطالب إلا أنه في

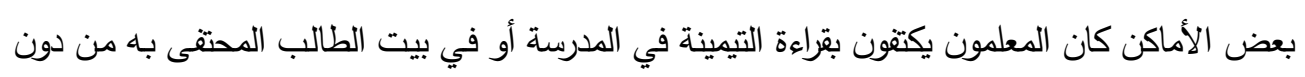

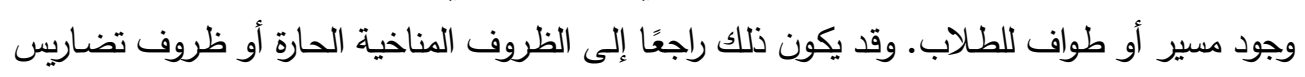

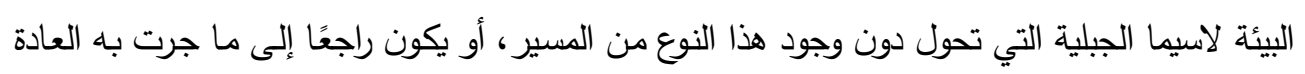
عند أهل القرية من استحبابهم للمسير أو عدمه. وتعتبر طريقة أداء التيمينة من عناصر التشويق التي تجعل الأطفال يستمرون في الاستماع لهذا الثعر المقدم لهم أو قراءته والاستمتاع به حتى النهاية من خلال ما تحدثه من متعة لديهم وتغيير في

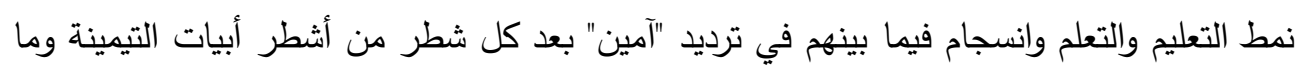
يصاحب ذلك من مرور وتطواف بالقرية وما يعقبه من تتاول للأكل. 
عاشراً: أنواع التيمينة:

من خلال تتبع ما أمكن الحصول عليه من تيمينات فقد قمنا بتقسيمها إلى نوعين اثنين هما:

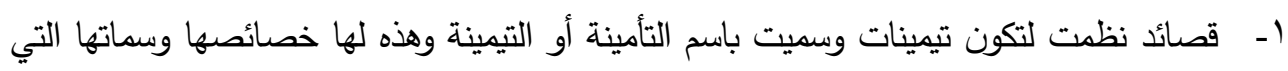
تثردت به كجنس أدبي وفن شعري مستقل بذاته. وقد أمدتا المخطوطات التي تم العثور عليها وجمعها بست عشرة قصيدة نظت وكتبت لتكون تيمينة حيث تعددت النسخ المخطوطة لبعضها

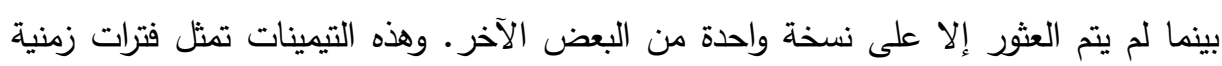

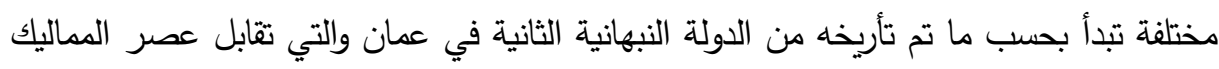
في العالم العربي والذي ازدهر فيه الثعر التعليمي ازدهارًا كبيرًا.

r- قصائد دينية تم استخدامها كتيمينة وأطلق عليها مسمى التيمينة أو التومينة لأنها كانت تقال التهال في حفل ختم الطالب القرآن الكريم بنفس طريقة أداء الأولى ولكنها لم تتظم في الأصل لتكون

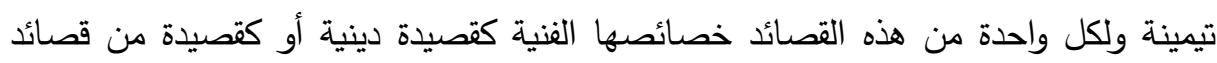
الزهد والحكمة.

وقد أمدنا البحث والاستقصاء إلى الوصول إلى سبع قصائد شعرية أساسية استخدمت فئس كتيمينات في المجتمع العماني بدءًا من الفترة الزمنية نفسها التي يعود إليها أقدم نص كتب ليكاء ليكون تيمينة وتم العثور عليه.

ومن هذه القصائد قصيدة سليمان النبهاني والتي أرخت نسخة منها كتيمينة في عام

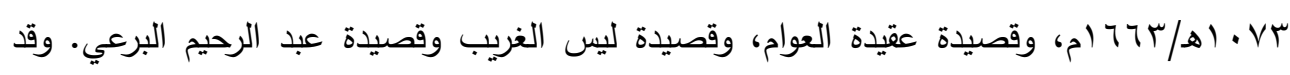

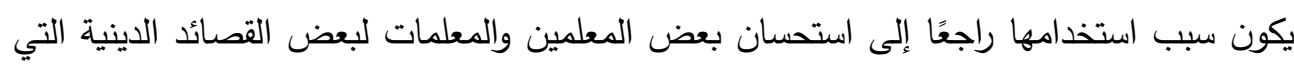

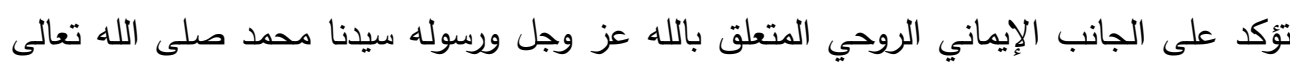

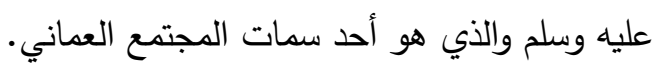
كما قد يكون راجعًا في بعض الأحيان إلى عدم وجود نسخ لدئ لدئ هؤلاء المعلمين والمعلمات

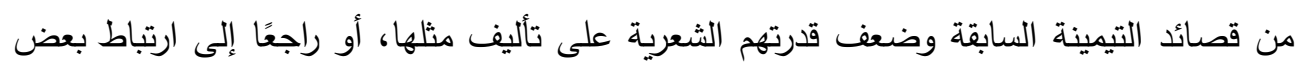

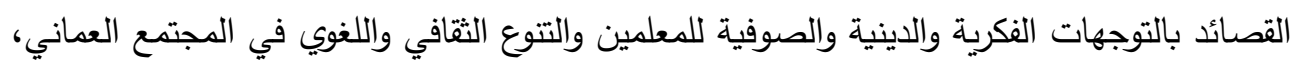

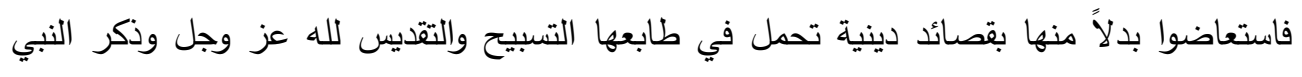

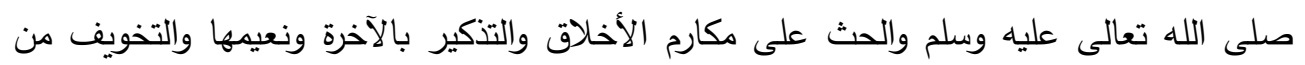


ولم يكن لها رابط يجمع بينها سوى هذا الجانب الديني والأخلاقي والاجتماعي فجعلها تحمل مسمى التيمينة نفسه. وهذه القصائد اختلفت عن القصائد التي كتبت لتكون تيمينة اختلافًا جوهريًّا في بناها وتثابهت معها في بعض المواضيع والمضامين الدينية والتربوية والاجتماعية.

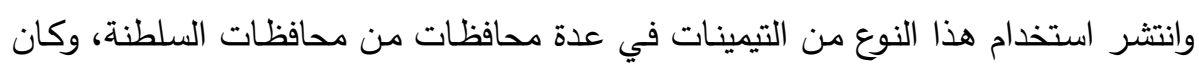

$$
\text { الدراسات السابقة: محافظة مسندم أكثر من غيرها. }
$$

من خـلال تتبع الدراسات السـابقة حول الثعر التعليمي أو التيمينـة فإنه لا توجد أي دراسـة

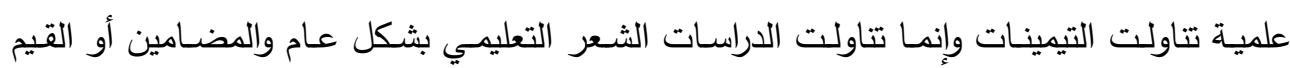
التربوية في هذا الشعر وفيما يأتي أهم هذه الدراسات:

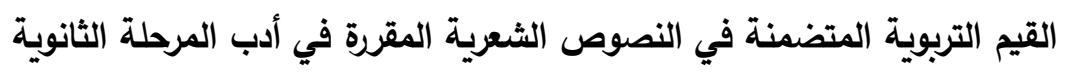

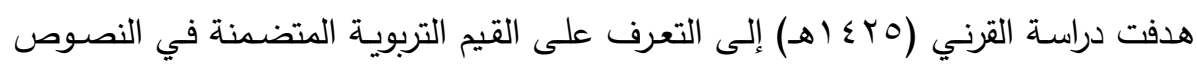

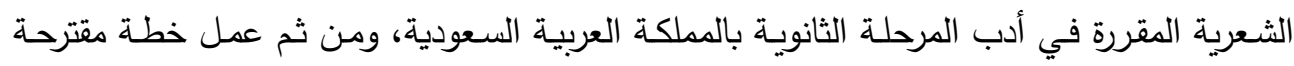

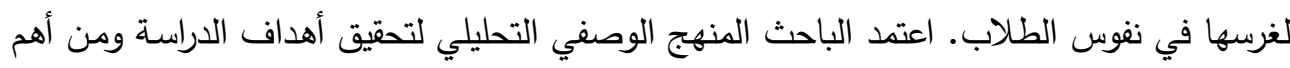

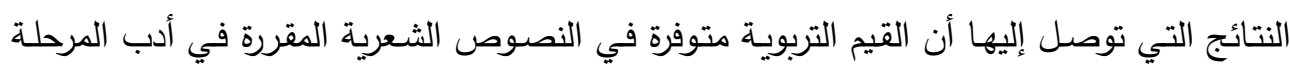

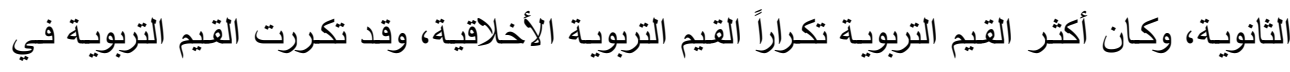

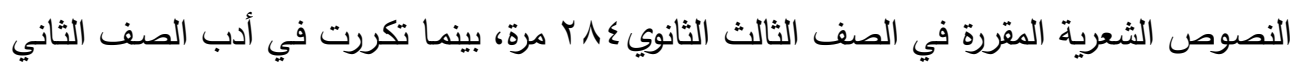

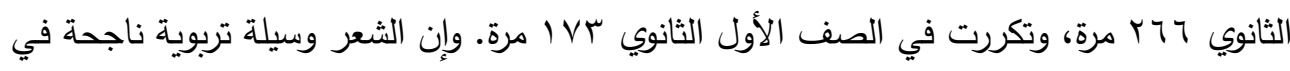
إكساب القيم التربوية للطلاب وتتمية استعداداتهم، وعلاج عيوبهم وإن بناء هذه القيم يتطلب تخطي التيطاً تربوياً عميقاً تشترك فيه جميع وسائط التربية.

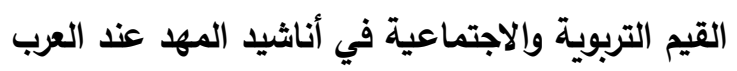

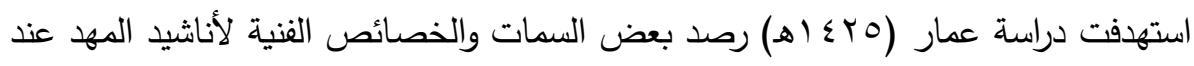

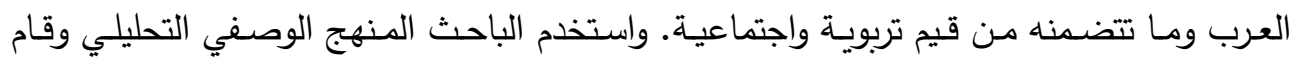
بتصنيف هذه الأناشيد في ثلاثة محساور وهي ظـلال الطفولـة، أحسلام المستقبل وأحاديث الأهل الهل

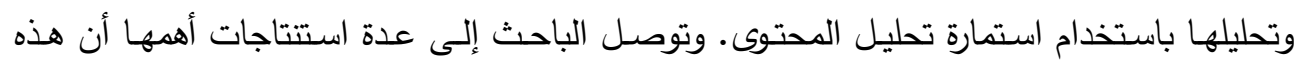

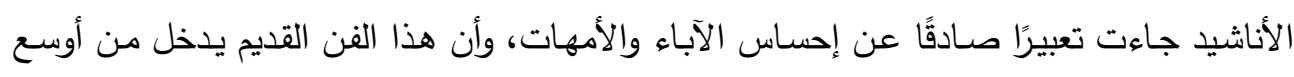

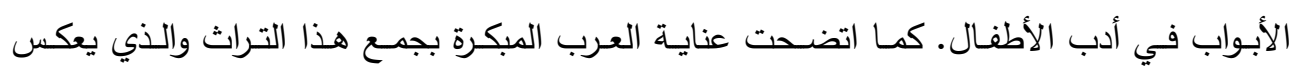

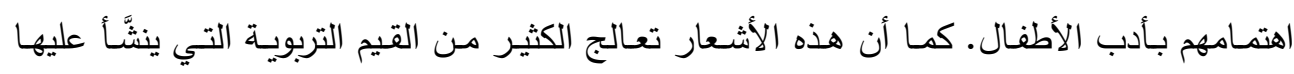


الأطفال في المجتمع العربي، كمـا تتضمن الكثير من القيم الاجتماعيـة والمضـامين التربويـة التي توضح العلاقات بين الناس وتعكس ما يبتغيه الآباء من أبنائهم في المستقبل.

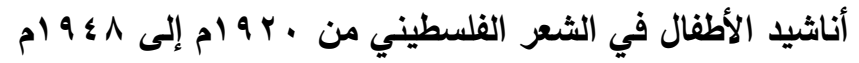

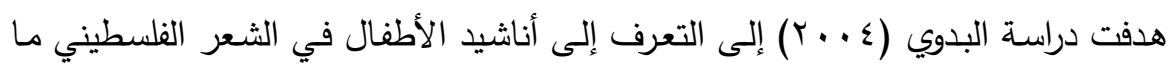

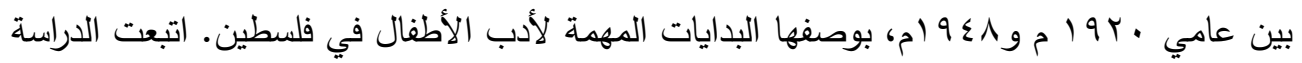

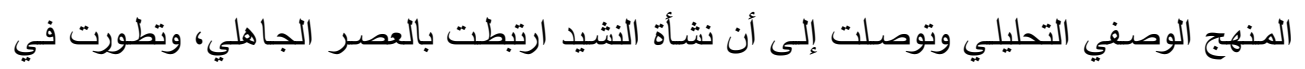

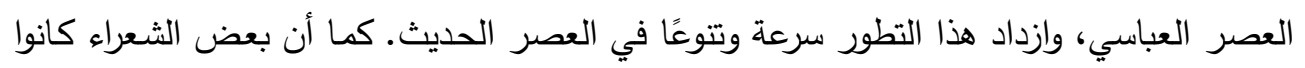

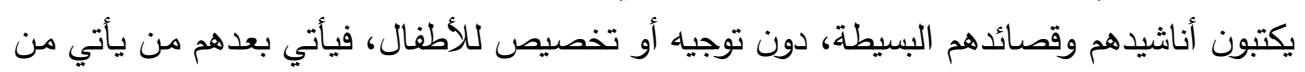

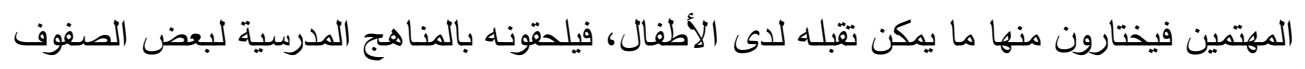

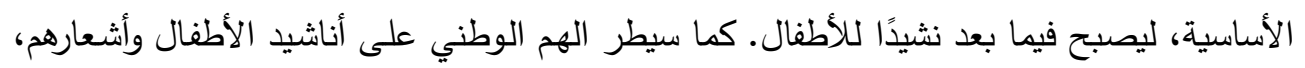

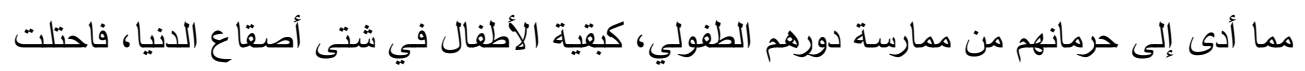
الأناشيد الوطنية المرتبة الأولى في أناشيد الأطفال في فلسطين.

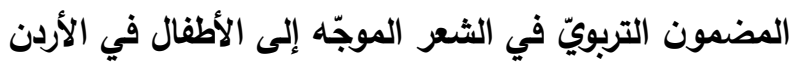

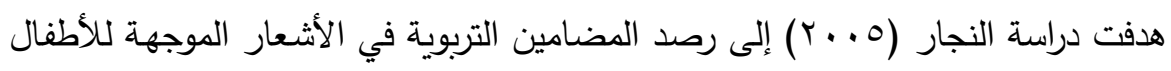

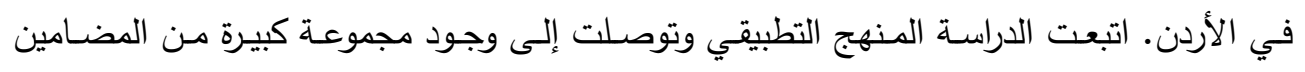

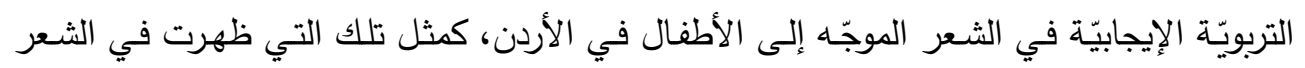

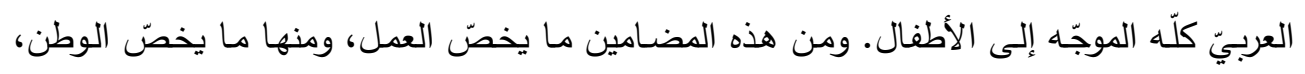

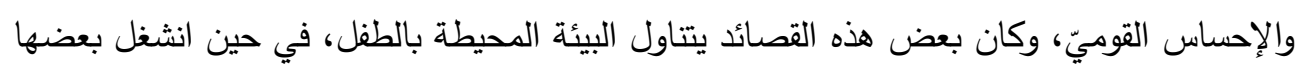

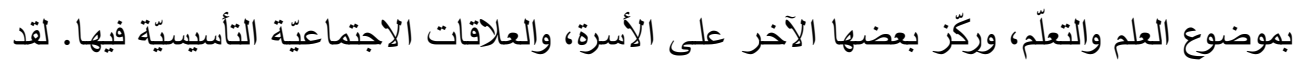

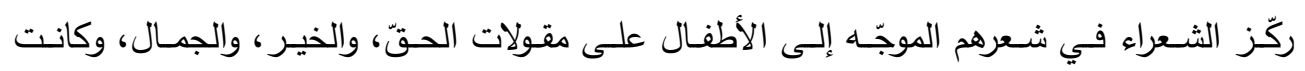

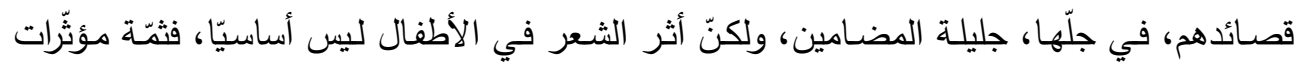

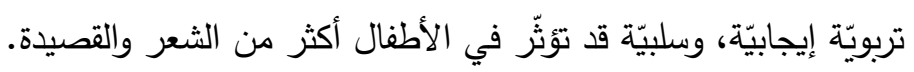

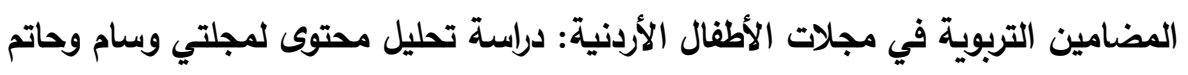

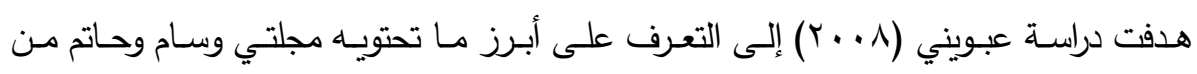

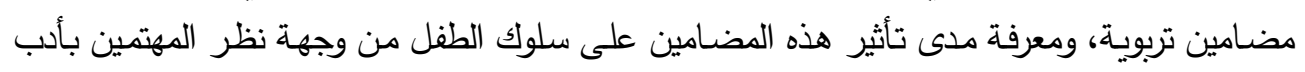

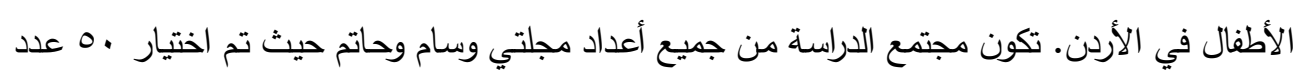

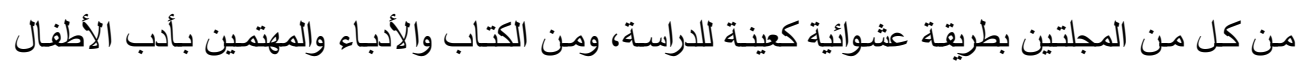

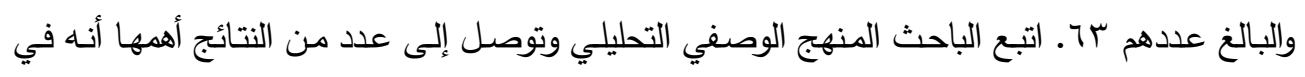


مجال المضمون التربوي كان الأعلى مرتبة في مجلة وسام المضمون الاجتماعي بينما في مجلة حاتم

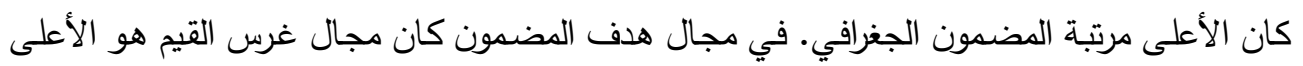

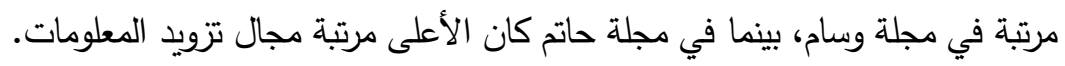

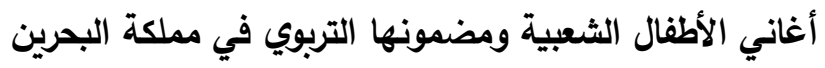

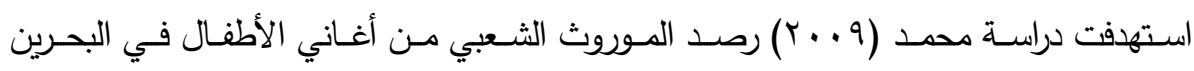
واستخلاص المضـامين التزبويـة منها، وبيـان المخـاطر التي تهدد بقاءهـا. واستخدمت الدراسـة المنهج

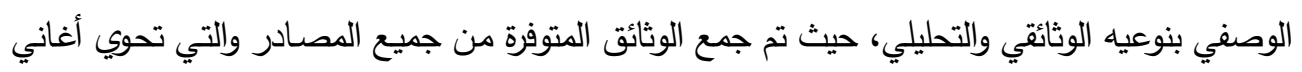

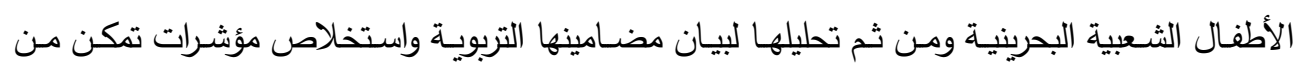

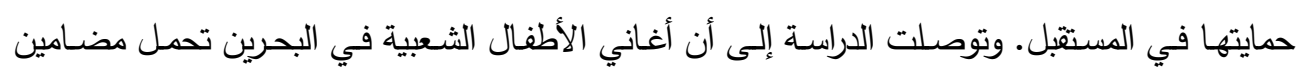

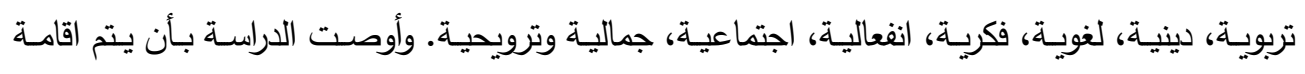

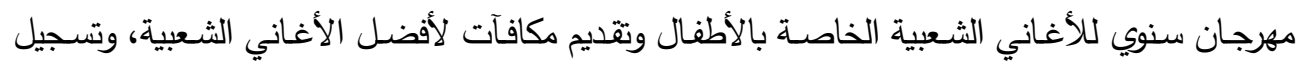

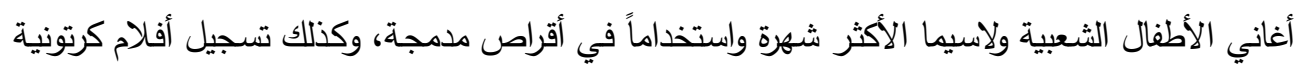
لأهم أغاني وأناشيد الأطفال الثعبية التي تجسد روح الانتماء والولاء والمواطنة وعرضها في التلفزيون البحريني. المضامين التربوية في شعر الأطفال في مصر في النصف الثاني من القرن العشرين

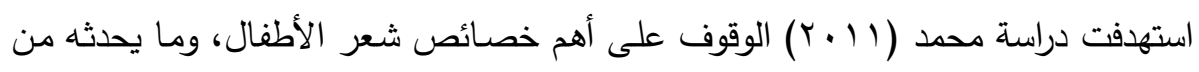

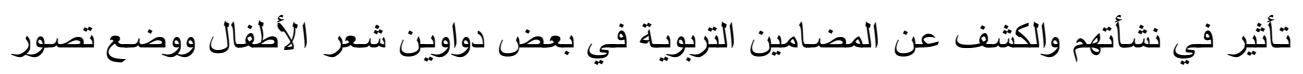

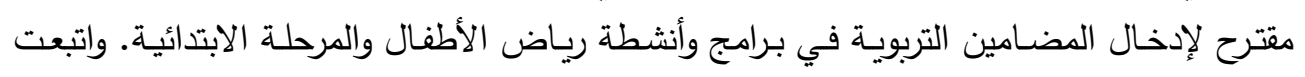

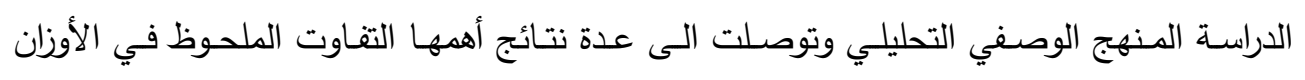

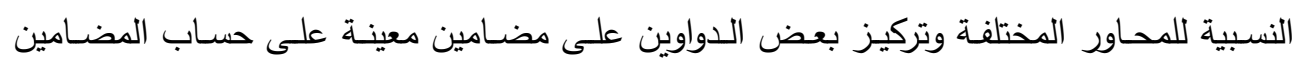

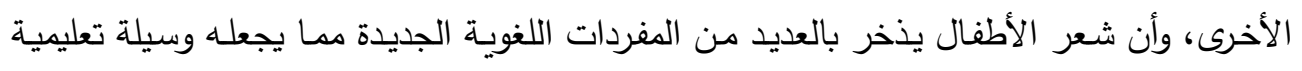

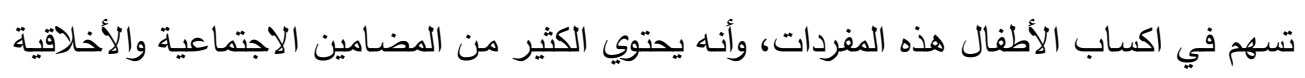

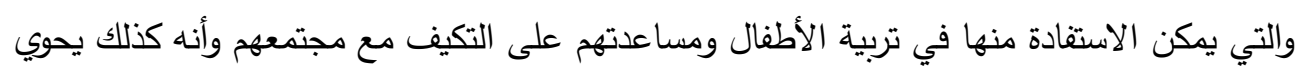
العديد من القيم المجتمعية ولذا يمكن استخدامه في غرس القيم المرغوبة في نفوس الأطفال.

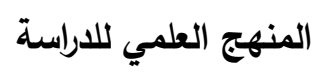
نظرًا لكون التيمينة ظاهرة متثعبة ومركبة من طبيعة ذات أربعة أبعاد تاريخية واجتماعية

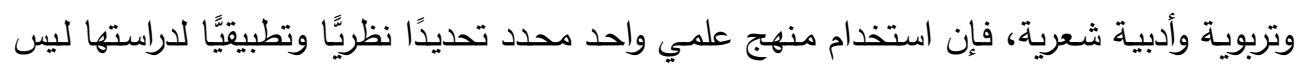

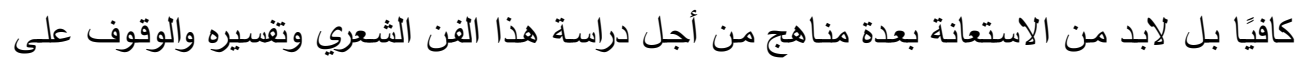


أجزائه التي يتكون منها والإحاطة به من جميع جوانبه التي تبين قيمته الحقيقية وسياقه الذي وضع فيه ومن أجله. ولنلك فقد اعتمدت هذه الدراسـة على تعدديـة المناهج والتي تهدف إلى التعامل مـع النص أو الظاهرة في ضوء مجموعة من المناهج والتخصصات العلمية والمعرفية المتداخلة والمتقاطعة التي تتدمج وتتفاعل فيما بينها لاستجلاء مختلف مستويات الدلالة النصية وتفسيرها من عدة زوايا لا يمكن تفسيرها

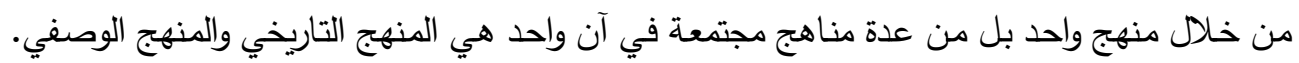

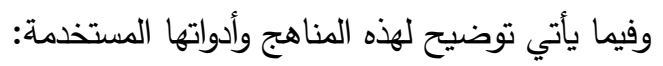

يعرف المنهج التاريخي بأنه "إعادة للماضي بواسطة جمع الأدلة وتقويمها، ومن ثم تمحيصها أولاً: المنهج التاريخي لئي توضيخ

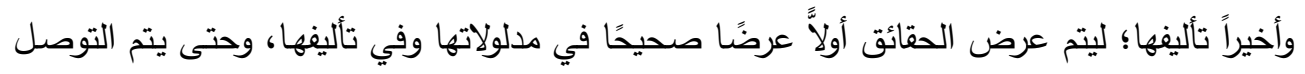

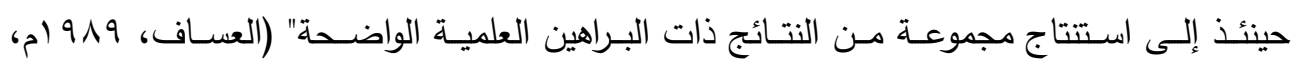
ص ص (rAr)

\section{وقد تم استخدامه من خلال الإجراءات الآتية:}

م تحديد المشكلة البحثية في البحث عن التيمينة التي كانت مستخدمة في عمان لمئات الأعوام.

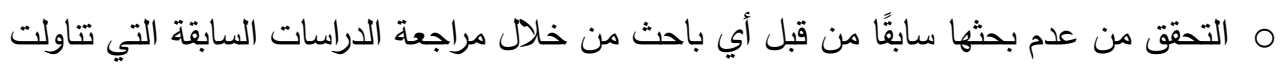

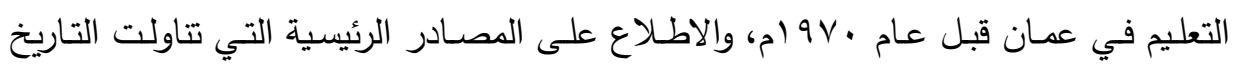
العماني. م القيام بزيـارات ميدانيـة لمحافظـات السلطنة والجهات الحكوميـة المعنيـة بالتراث العماني والمكتبات الخاصة التي تحتوي العديد من المخطوطات والوثائق والسجلات الخاصة بالتيمينات، والتواصل مع ولئ الأثخاص والباحثين الذين يمتلكون مخطوطات أو نسخًا من مخطوطات تيمينة من أجل البحث

عن هذه التيمينات وجمعها والاطلاع عليها وتصويرها.

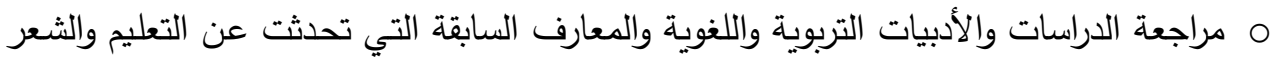
التعليمي المنظوم وأدب الأطفال.

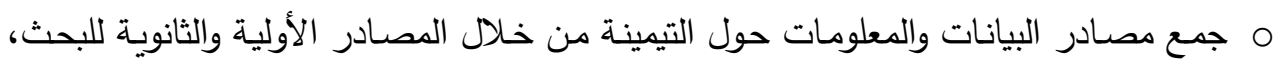
ومن ثم تصنيف هذه البيانات والمعلومات. م فحص ما تم الحصول عليه من مخطوطات التيمينات. م تحليل ما تم الحصول عليه عن التيمينة ودراسته دراسة تاريخية وأدبية ولغوية وتربوية.

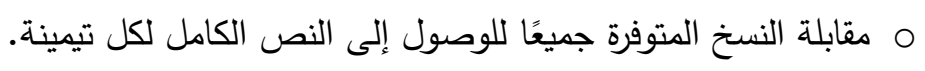


م تحقيق ما تم الحصول عليه من مخطوطات عن التيمينة وتصحيح ما ورد فيها من أخطاء أو نواقص بسبب تلف بعض تلك المخطوطات. م طباعة التيمينات وكتابتها وتثكيل الكلمات، وشرح كثير من المفردات والمسميات الواردة فيها

يعرف المنهج الوصفي بأنه "مجموعة الإجراءات البحثية التي تتكامل لوصف الظـاهرة أو

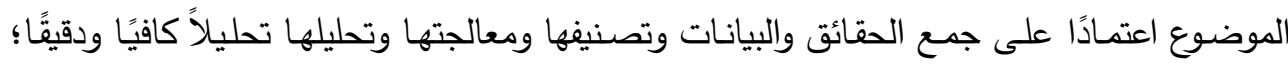

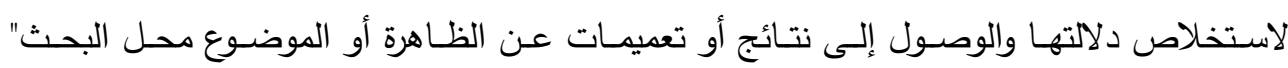

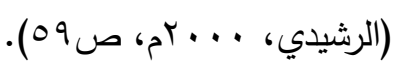
وتم استخدامه من خـلال أسلوب تحليل المحتوى (تحليل المضـمون) لنصـوص التيمينـات

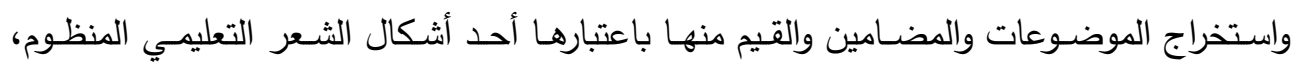
والاستعانة بالمراجع والدراسات التي تتاولت القيم التربوية الإسلامية واستخلاص الأفكارئ والتار منها. وقد قمنا بالتحليل وفقا للخطوات الآتية: أـ تحقيق مخطوطات التيمينات وضبط النصوص الواردة فيها وتصحيح الأخطاء الإملائية الواردة

$$
\text { في نسخ المخطوطات. }
$$
بـ التعريف بالمجال الرئيسي الذي يتم في ضـوئه التحليل: حيث يتحدد هذا المجال في هذه الدراسة في المنظومة القيمية في التيمينات.

ج- تحديد وحدات التحليل: وفي ضوه هذه الدراسة اعتبرت نصوص التيمينات هي وحدة التحليل .

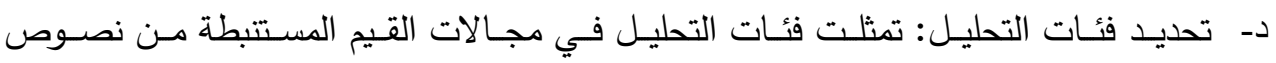
التيمينات. ه- تحديد معايير التحليل: تمثلت معايير التحليل في النظر في نصوص التيمينات وتحديد ما هو

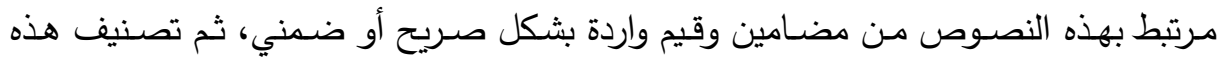
المضامين والقيم في مجالات قيمية تتنتي إليها هذه المضامين والقيم. و - تحليل نصوص التيمينات لاستخراج القيم الواردة في المخطوطات.

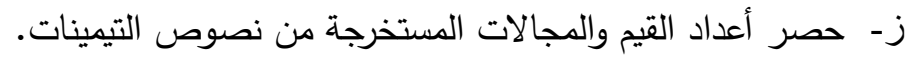
ح- عرض النتائج وتحليلها. مجتمع الدر اسة و عينتها: 
يتكون مجتمع الدراسة وعينتها من جميع قصائد التيمينات التي تم الحصول عليها وتوثيقها

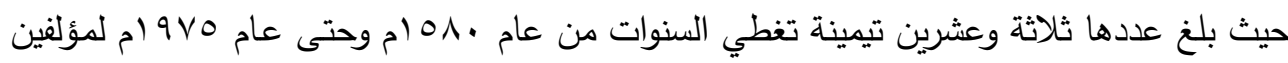

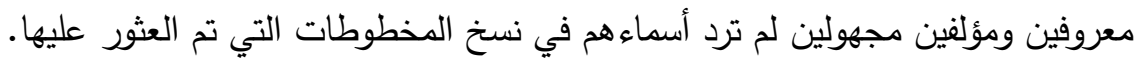

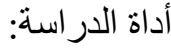

اعتمد الباحث على أسلوب تحليل المحتوى وذلك بتصميم "بطاقة تحليل المحتوى" كأداة في عملية التحليل لنصوص التيمينات لاستخراج المضامين التربوية بحيث تم بناؤها اعتمادًا على الأدب التربوي والدراسات السابقة التي تتاولت موضوع القيم إضافة إلى خبرة الباحث العلمية والتربوية.

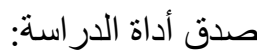

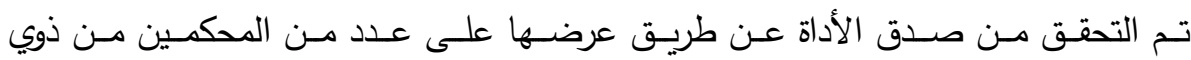
الاختصاص والخبرة في مجال البحث العلمي والأصول التربوية والعلوم الإسلامية.

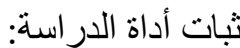

للتأكد من ثبات تحليل المحتوى، قام الباحث بالاستعانة بمحلل آخر لتحليل بعض من قصائد التيمينة وذلك في خطوتين: الخطوة الأولى: تحديد مجموعة من التيمينات كعينة مختارة للتحليل. الخطـوة الثانيـة: تحليـل هذه العينـة المختارة مـن التيمينـات واستخراج المضــامين والقيم التربويـة المتضمنة فيها. وقد قام الباحث بإطلاع المحلل الآخر على طريقة ومنهجية التحليل وآلية استخراج المضامين من كل نص شعري وضوابط التحليل التي يجب اتباعها في ذلك بعدها قارن الباحث نتائج التحليل

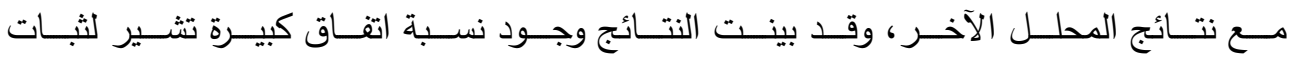

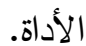

$$
\text { نتائج الدر اسة }
$$

\section{نتائج السؤال: ما القيم التربوية المتضمنة في قصيدة التيمينة؟}

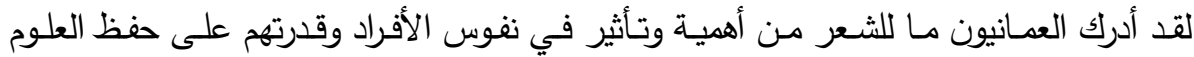
وتعلمها من خلال الثعر فاستخدموه في نظم الأراجيز والقصائد التي تتتاول مختلف العلوم لاسيما علوم الثربعة الإسلامية واللغة العربية بمختلف مجالاتها وتقسيماتها.

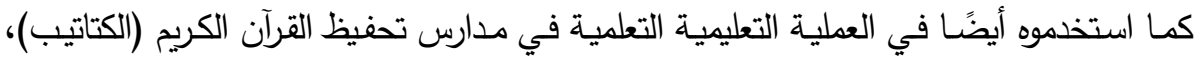

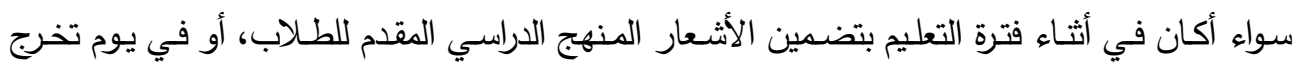
الطالب من المدرسة وختمه (قراءته) للقرآن الكريم كاملا فيما أطلق عليه "التيمينة". 
وعملت المدرسـة العمانية على أن تكون أهدافها التربويـة وغاياتها مشتقة من القيم التربويـة الإسلامية ومستمدة منها، فركزت على غرس القيم في الطلاب، وتحسين التعلم الفعال القائم على مبدأ

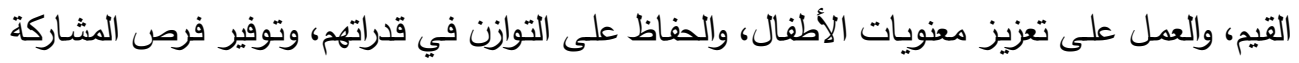

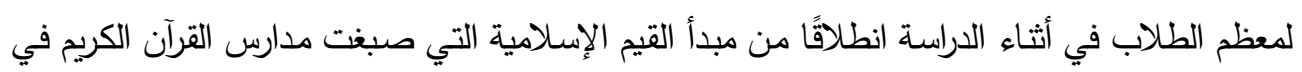
عمان. ولذلك تضمنت قصائد التيمينة العديد من المفاهيم والآراء والمبادئ والمعايير والأسس والأساليب

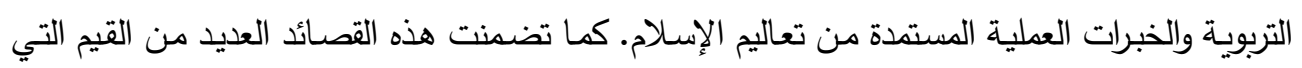
تهدف إلى حث الطلاب على التصكك بها وعدم تجاهلها حتى وإن تخرج الطالب من المدرسة لتكون هذه التها القيم دليلا له في حياته كلها.

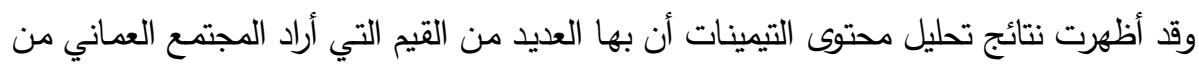

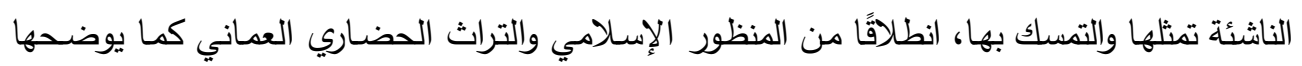

الثكل (1) تصنيف منظومة القيم التربوية في

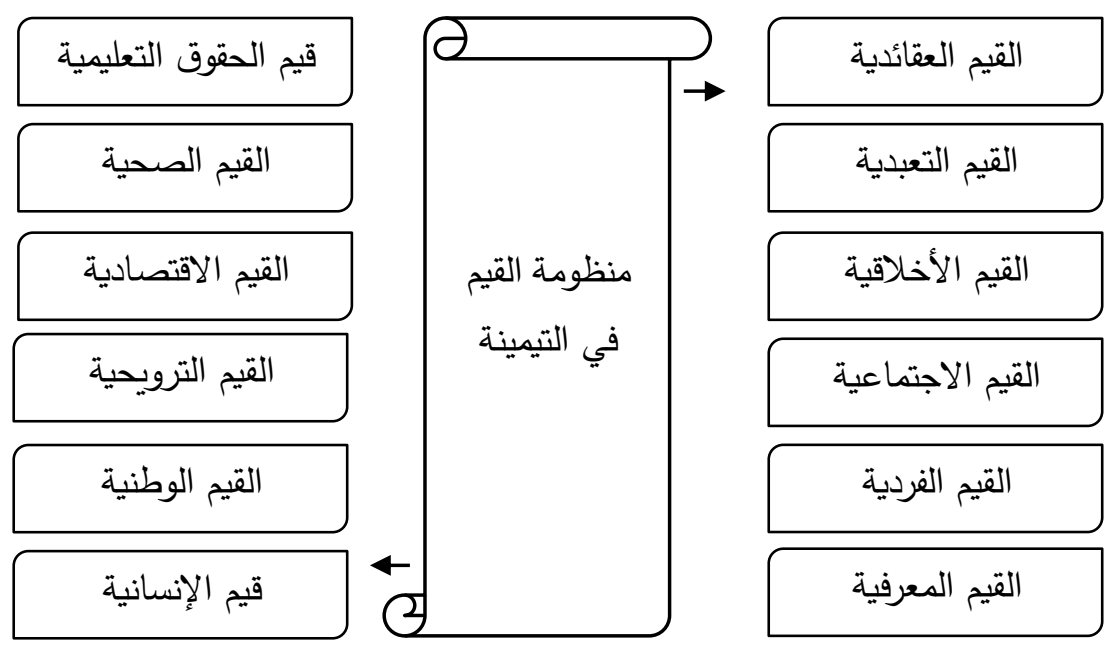

إن الثكل السابق يبين أن منظومة القيم في التيمينات تتكون من اثثي عشر قسمًا هي القيم العقائدية والتعبدية والأخلاقية والمعرفية والاجتماعية والثردية والبئية والترويحية والاقتصادية والسياسية والتي تم توضيحها في تصنيف الدرابسة (1 . . ب) للقيم الإسلامية، إضافة إلى القيم 
الصحية التي تعنى بالاهتمام بالنظافة والصحة، وقيم الحقوق التعليمية المتعلقة بحقوق الطفل وواجباته تجاه المعلم وحقوق المعلم وواجباته تجاه الطلاب وقيم الإنسانية. وفيما يأتي أمثلة لهذه القيم من نصوص التيمينات:

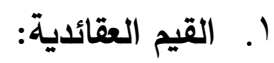
م الإيمان بالله تعالى، ومن ذلك قالكة قول الثاعر :

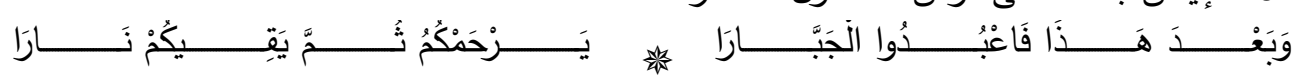

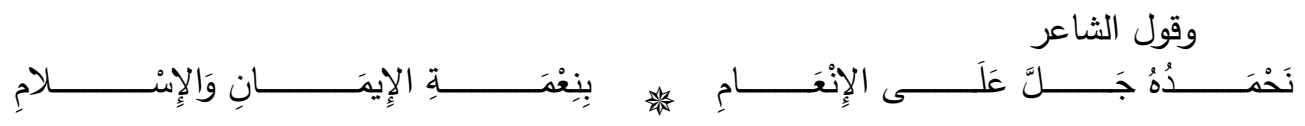
م الإيمان بالملائكة، ومن ذلك قول الثاعر :

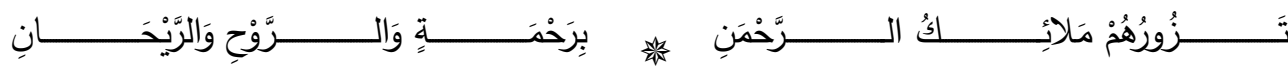
م الإيمان بالكتب المنزلة من عند الله عز وجل، ومن ذلك قول الثاعر :

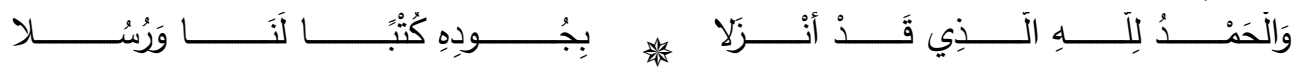
o

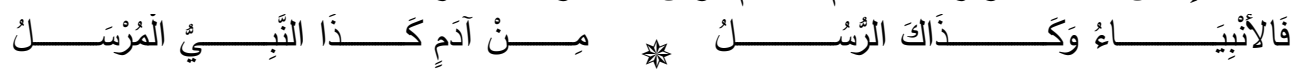

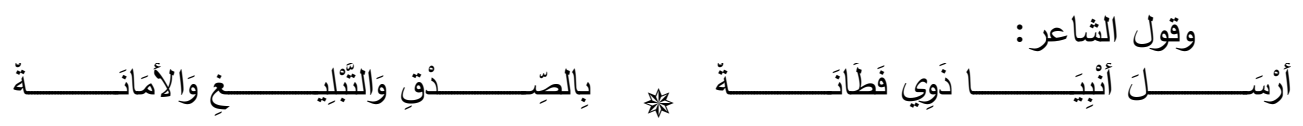

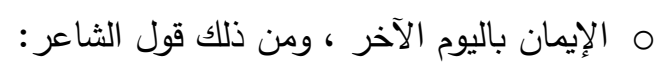

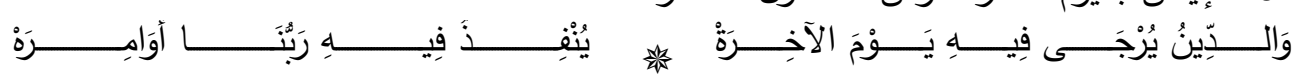

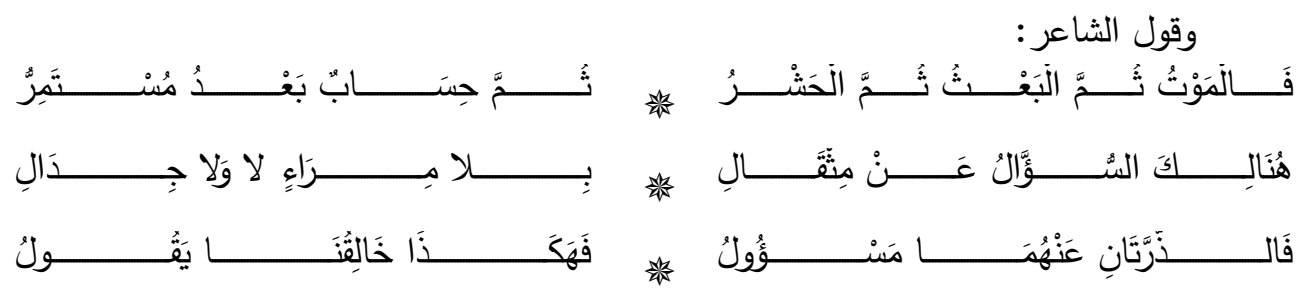
م الإيمان بالقضاء والقدر ، ومن ذلك قول الثاعر :

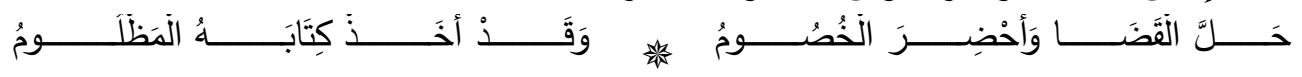

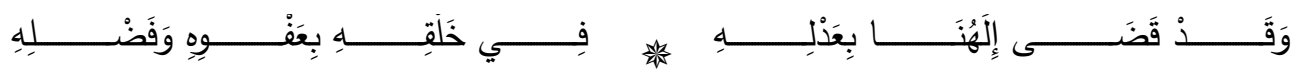




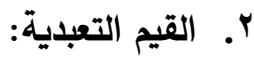

م التقوى، ومن ذلك قول الثاعر :

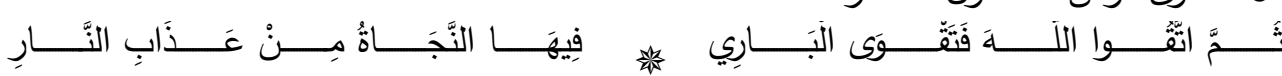

م الصلاة، ومن ذلك قول الثاعر:

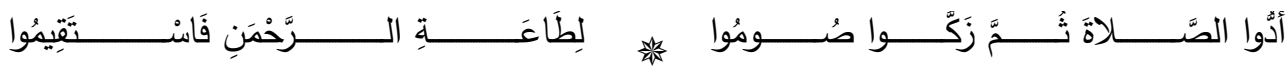

م الصوم، ومن ذلك قول الثاعر :

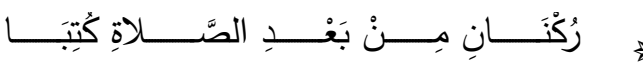

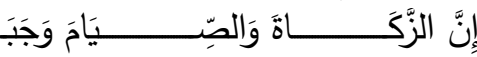

O الزكاة، ومن ذلك قول الثاعر:

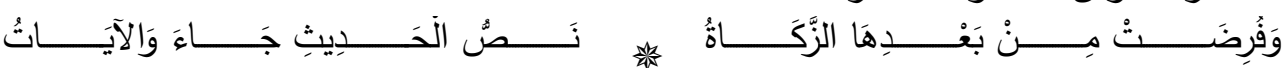
م الحج، ومن ذلك قول الثاعر :

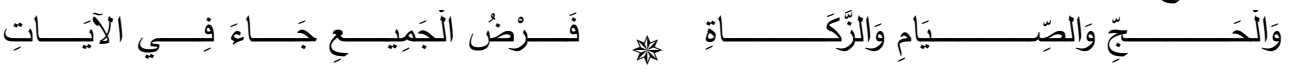
وقول الثاعر:

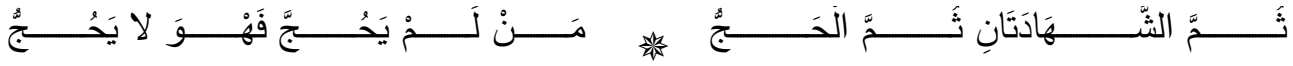
م المديح الإلهي، وهو كثير بل إنه أمر أساسي في التيمينات، ومن ذلك قول الثاعر:

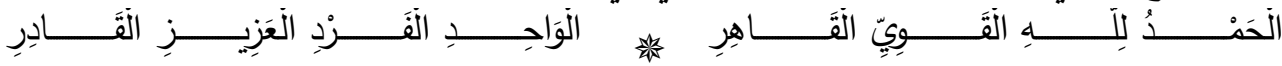

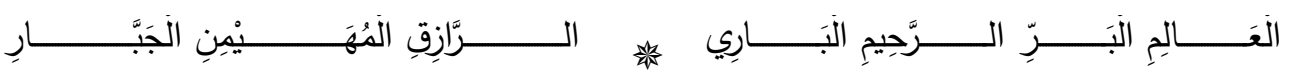

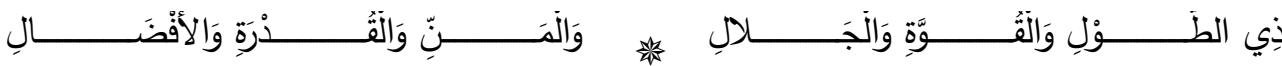
م المديح النبوي، وهو أيضًا كثير بل إنه أمر أساسي في التيمينات، ومن ذلك قول الثاعر:

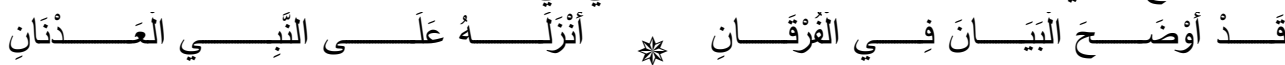

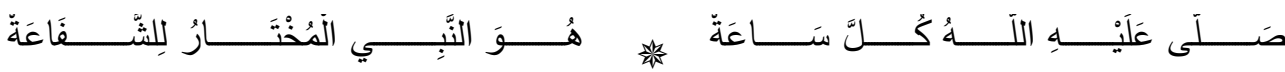

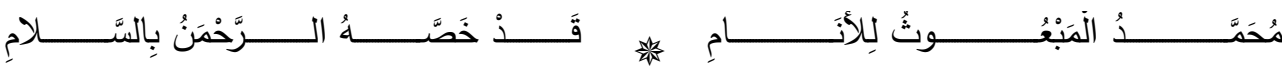

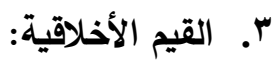

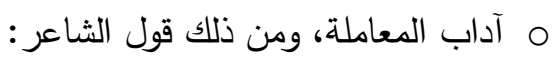

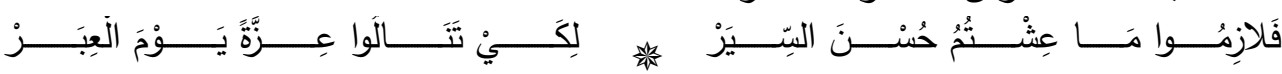


م الصدق واجتتاب الكذب، ومن ذلك قول الثاعر:

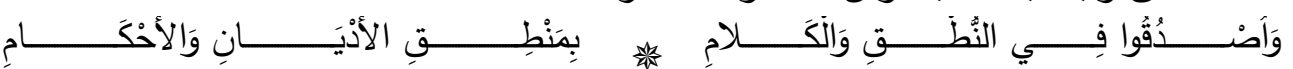

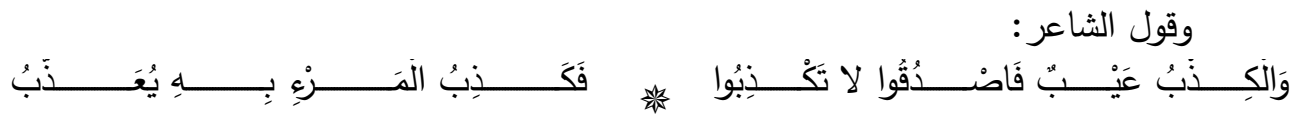

م الكرم، ومن ذلك قول الثاعر:

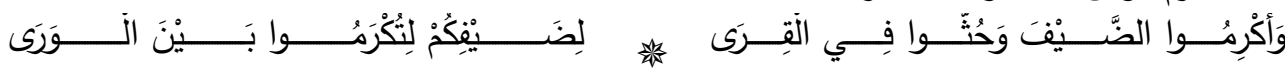

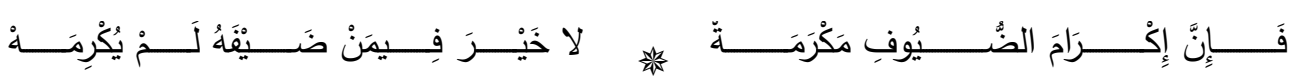

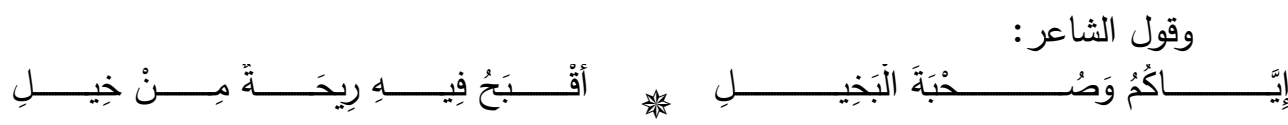
م التسامح، ومن ذلك قول الثَاعر:

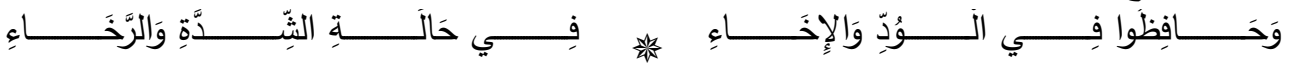

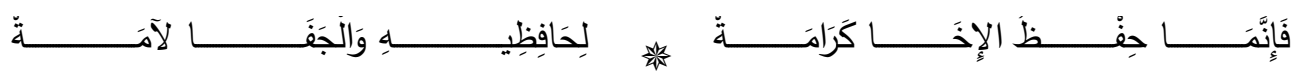

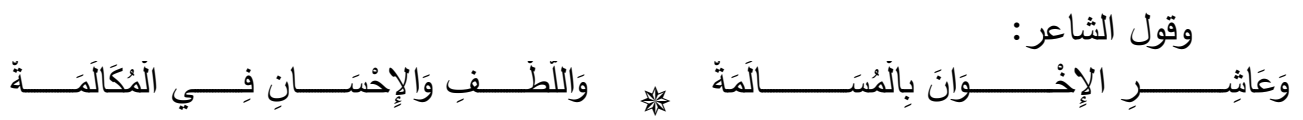

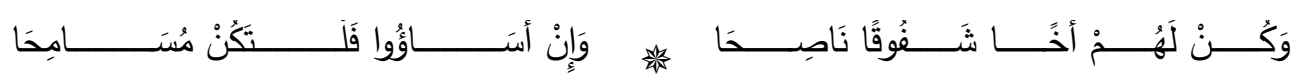

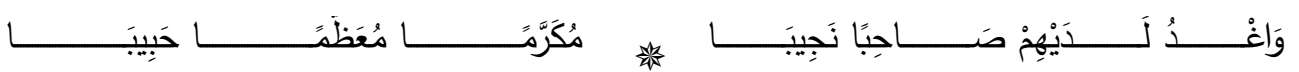

م الأمانة، ومن ذلك قول الثاعر:

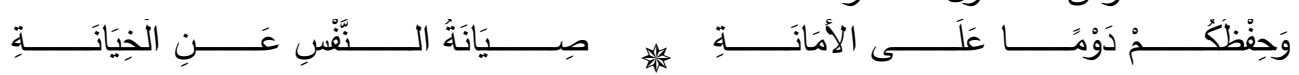

O مدم إفثاء الأسرار، ومن ذلك قول الثاعر:

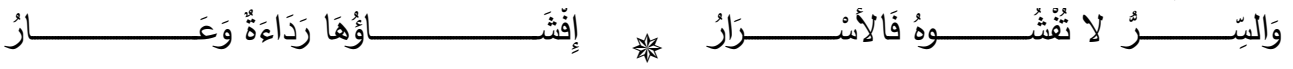


م احترام الآخرين، ومن ذلك قول الثاعر:

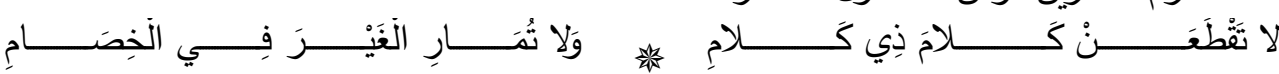

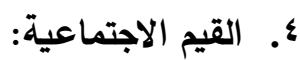

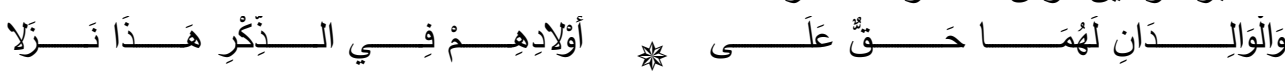

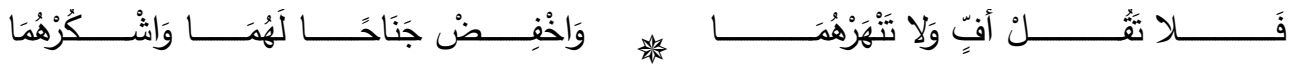

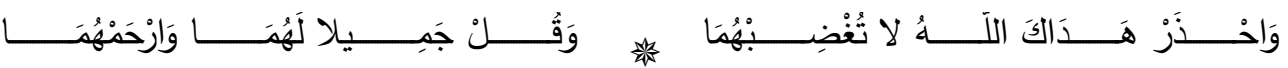

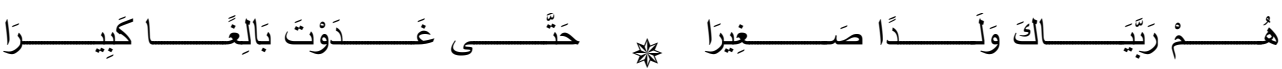

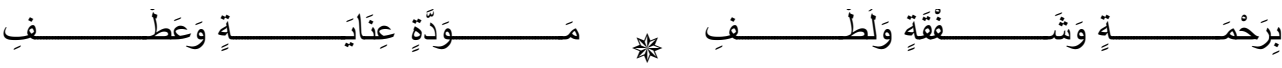
م التكافل، ومن ذلك قول الثاعر :

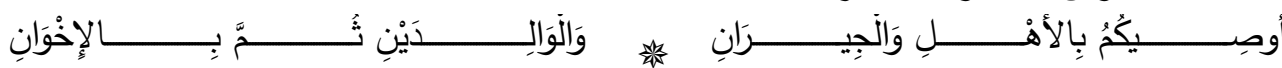
م صلة الرحم، ومن ذلك قول الثاعر:

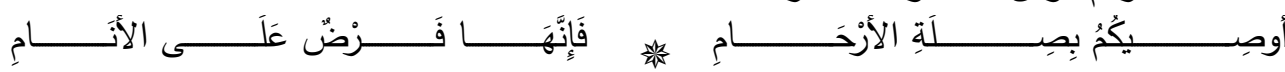

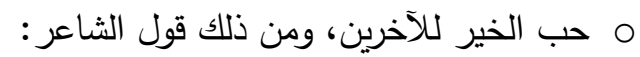

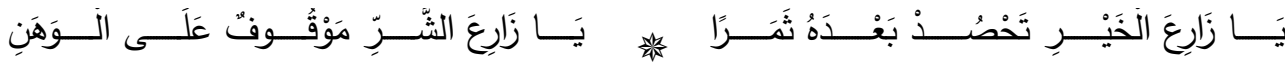
م الصداقة، ومن ذلك قول الشاعر:

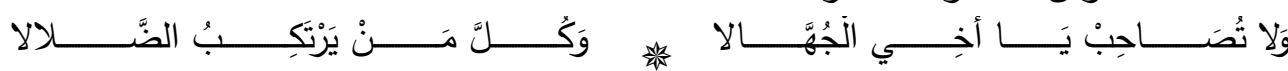

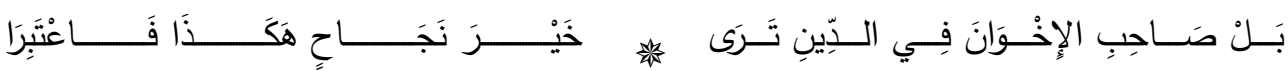
وقول الثاعر:

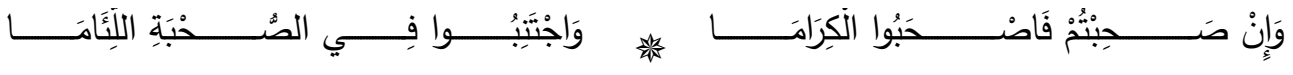

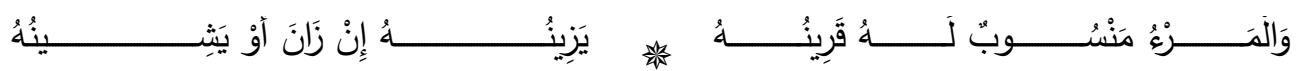
م حسن الجوار، ومن ذلك قول الثاعر:

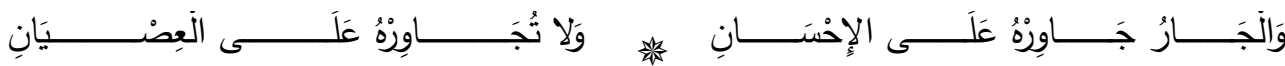

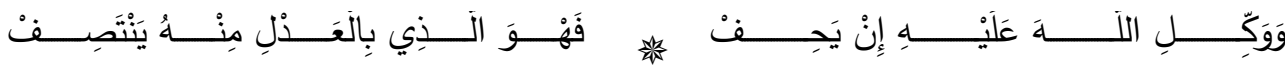


م تجنب أذية الطريق، ومن ذلك قول الثاعر:

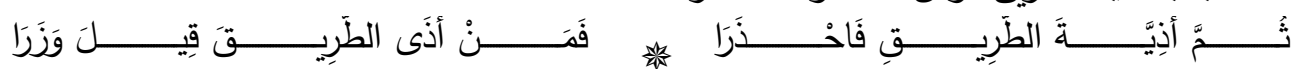

O البعد عن فاحش الكلام، ومن ذلك قول الثاعر:

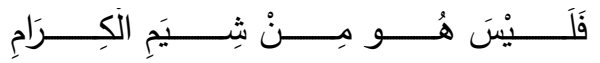

䍒

لَعَلَهَ

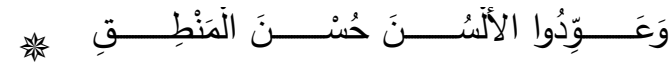

م الاجتهاد في الرشد واجتناب الغي والضلالة:

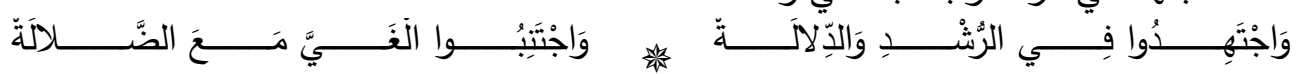

م الأمر بالمعروف والنهي عن المنكر ، ومن ذلك قول الثاعر:

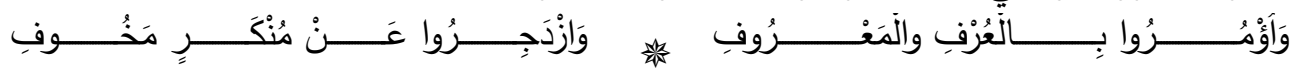

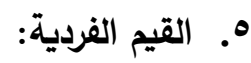

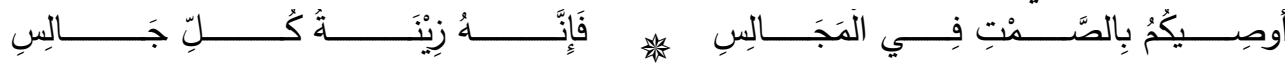

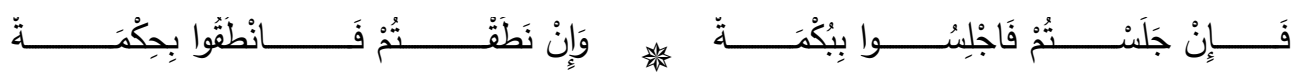

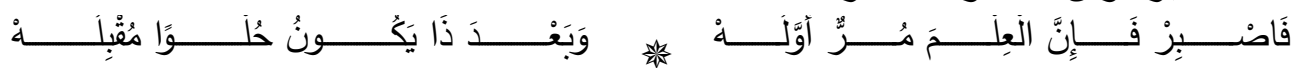

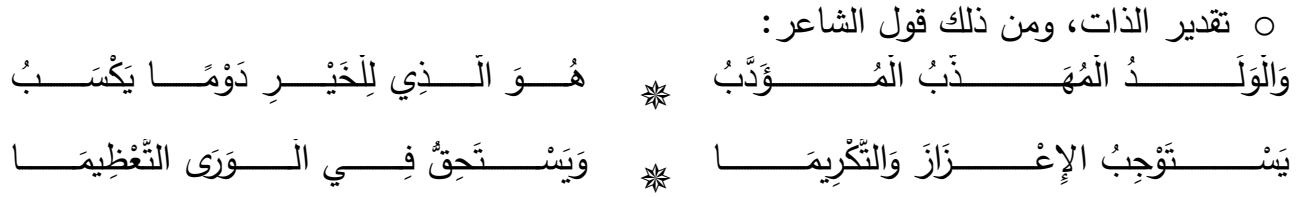

م تحمل المسؤولية، ومن ذلك قول الثاعر:

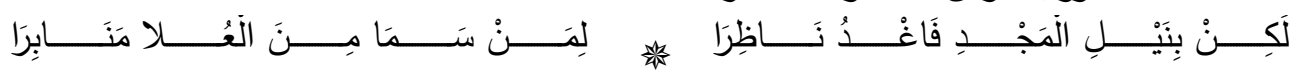

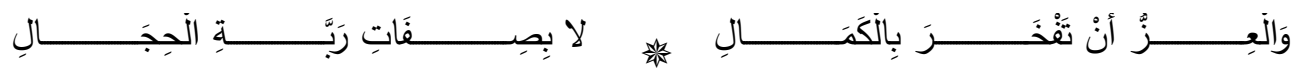

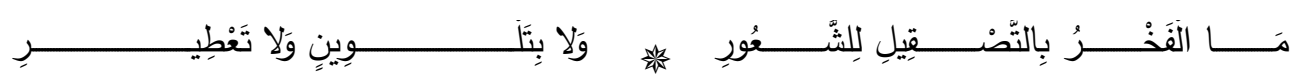

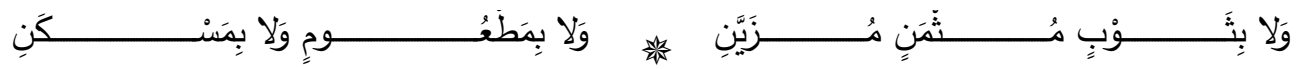

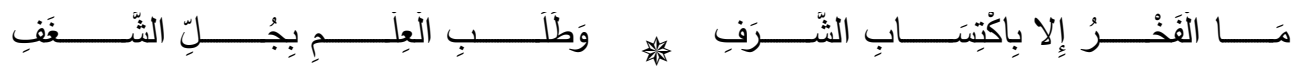


O جهاد النفس، ومن ذلك قول الثاعر:

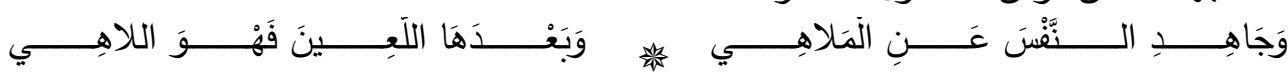
م الابتعاد عن الصفات المذمومة كالعجب والرياء والحسد والطمع، ومن ذلك قول الثاعر :

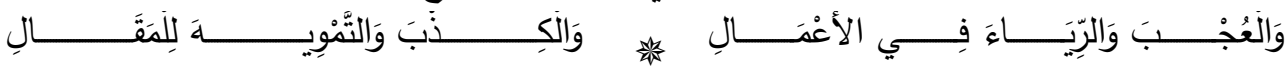

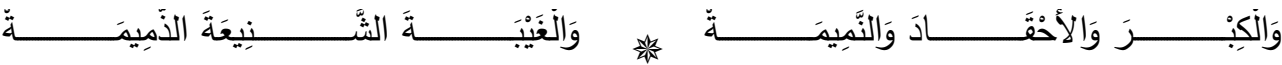

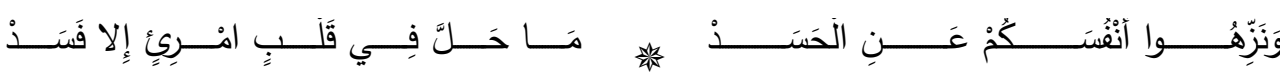

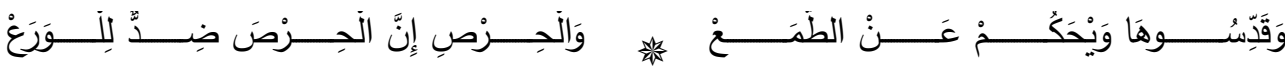

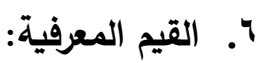
م طلب العلم، ومن ذلك قول الثاعر:

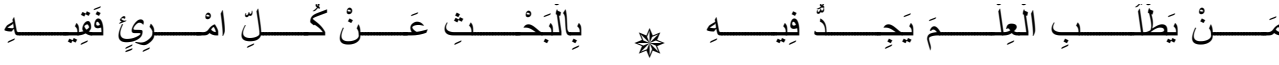

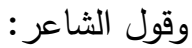

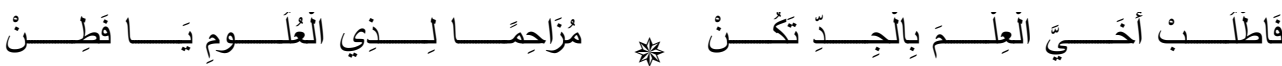

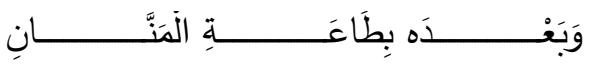

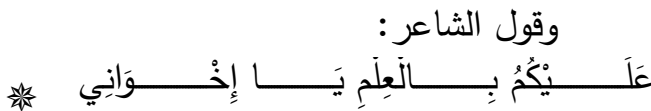

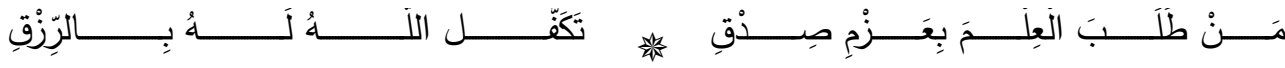

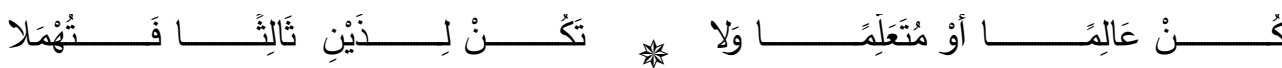
م نشر العلم، ومن ذلك قول الثاعر:

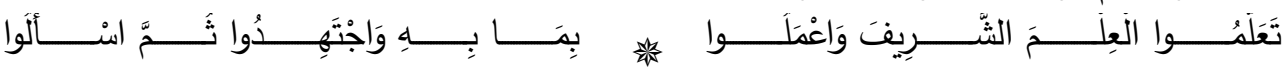
م تقدير العقل، ومن ذلك قول الثاعر:

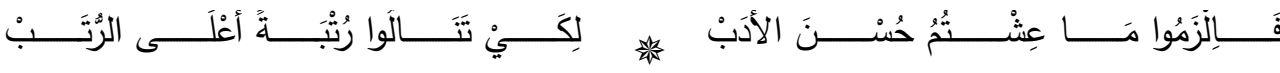

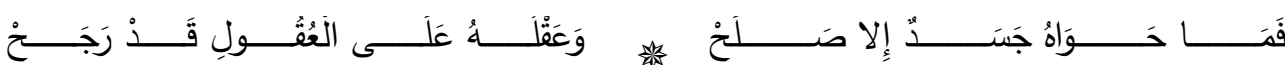

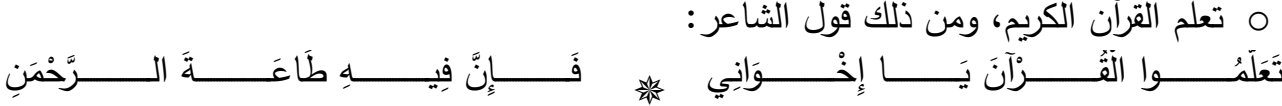


م تعلم الحديث، ومن ذلك قول الثاعر:

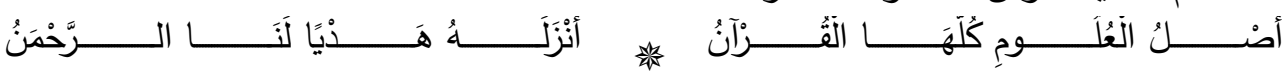

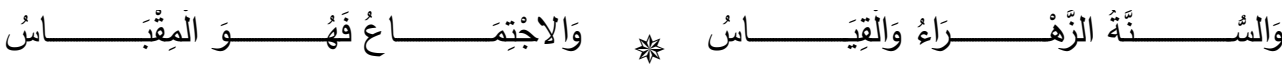
م تعلم الثرائع والفقه، ومن ذلك قول الثاعر:

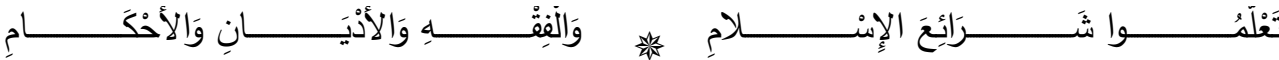
م إنشاد الأشعار والأخبار ، ومن ذلك قول الثاعر :

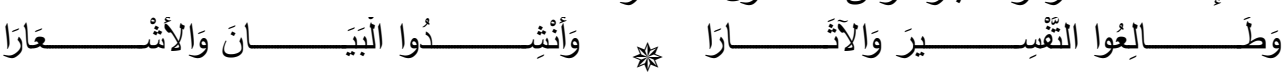
O تعلم الحساب والضرب، ومن ذلك قول الثاعر :

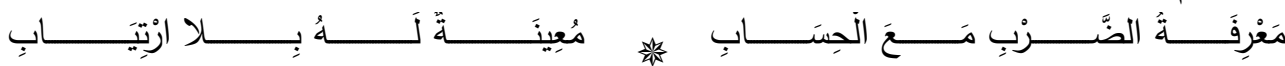
م تعلم الطب، ومن ذلك قول الثاعر:

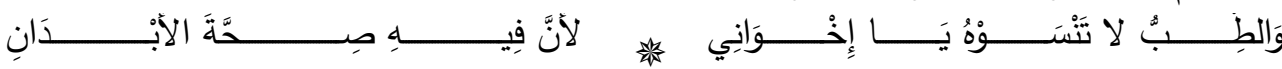
وقد قرن عدد من الشعراء أهمية المعلم بأهمية الطبيب، ومن ذلك قول الثاعر :

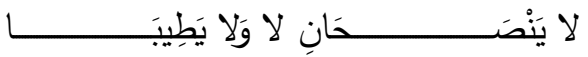

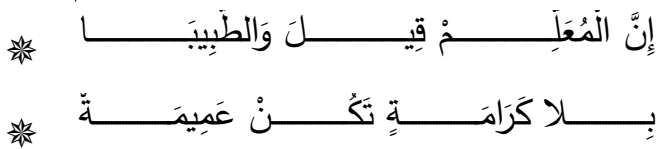
عَلَيْهِهَ م تعلم علم المواريث، ومن ذلك قول الثاعر:

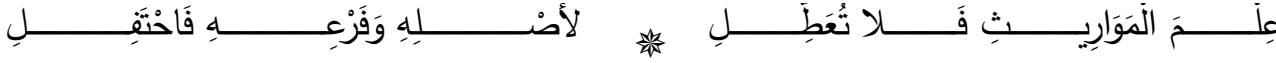
م تعلم علوم اللغة العربية كالنحو والصرف، ومن ذلك قول الثاعر:

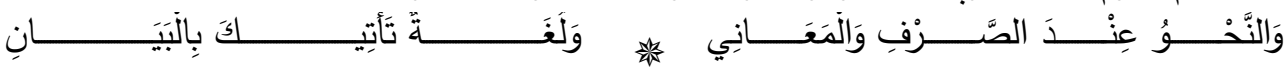

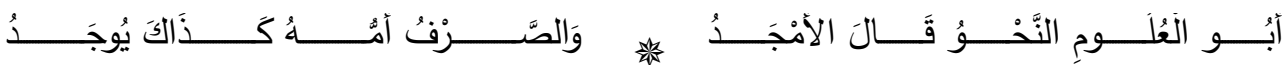

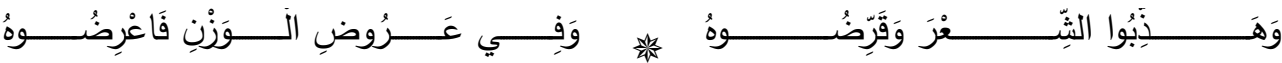
م الاهتمام بالكتابة وحسن الخط، ومن ذلك قول الثاعر:

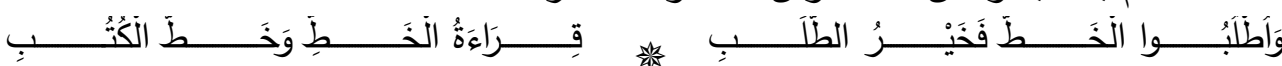

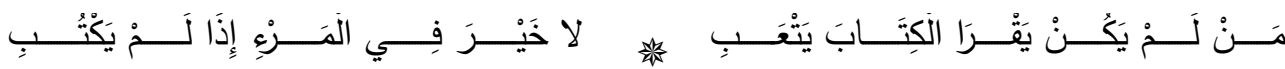




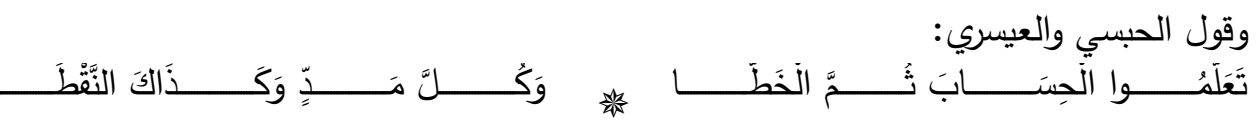
م التبكير في الذهاب للمدرسة، ومن ذلك قول الثاعر :

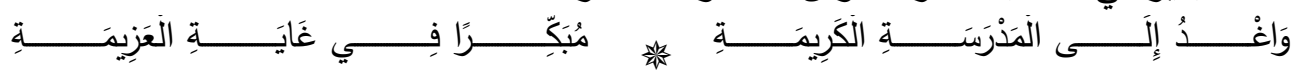

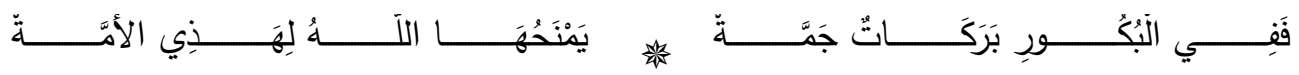

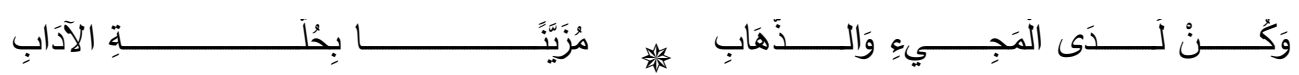
V. قيم الحقوق التعليمية: وتثمل حقوق المعلم وحقوق الطالب ومنها:

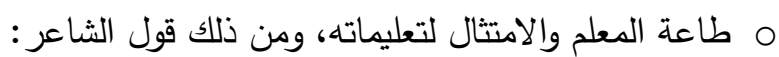

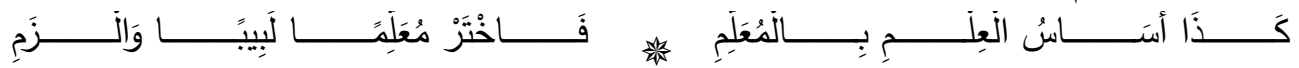

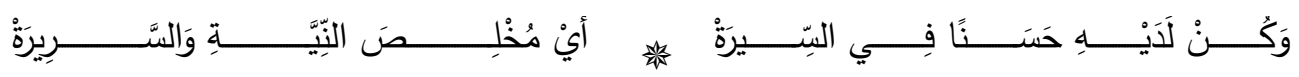

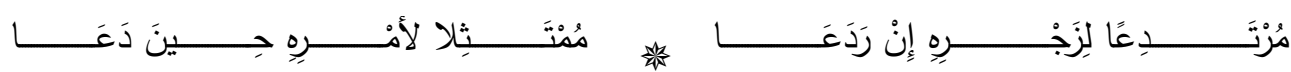

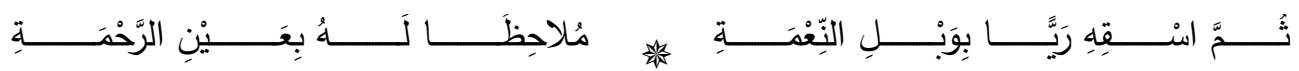
م إكرام المعلم، ومن ذلك قول الثاعر :

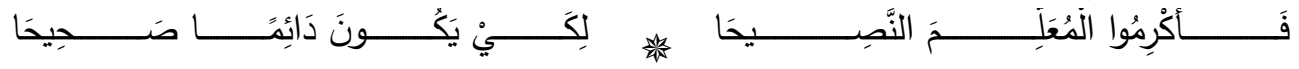

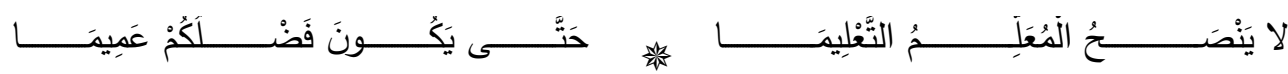

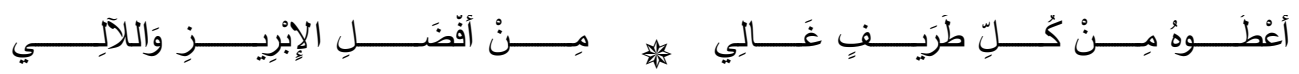
م تكريم الطالب من قبل والديه وأهله وحقه عليهم في الحصول على التعليم، ومن ذلك قول

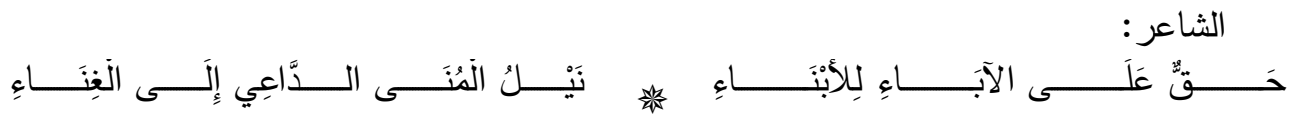

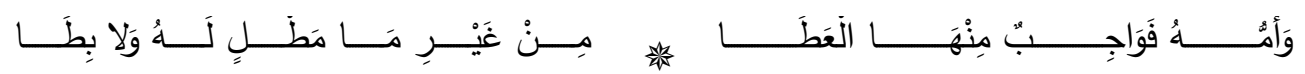

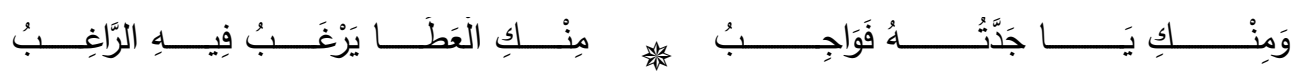
م تشجيع الطالب المجيد (الخاتم للقرآن الكريم) والفخر به، ومن ذلك قول الثاعر :

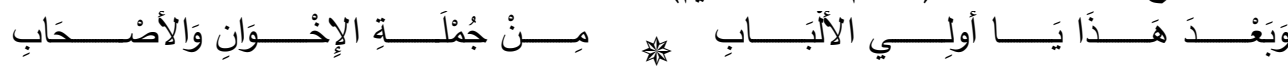

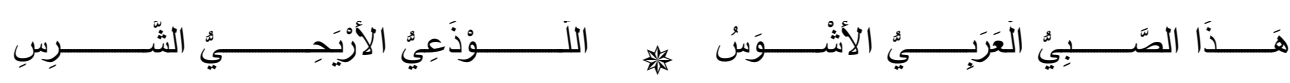




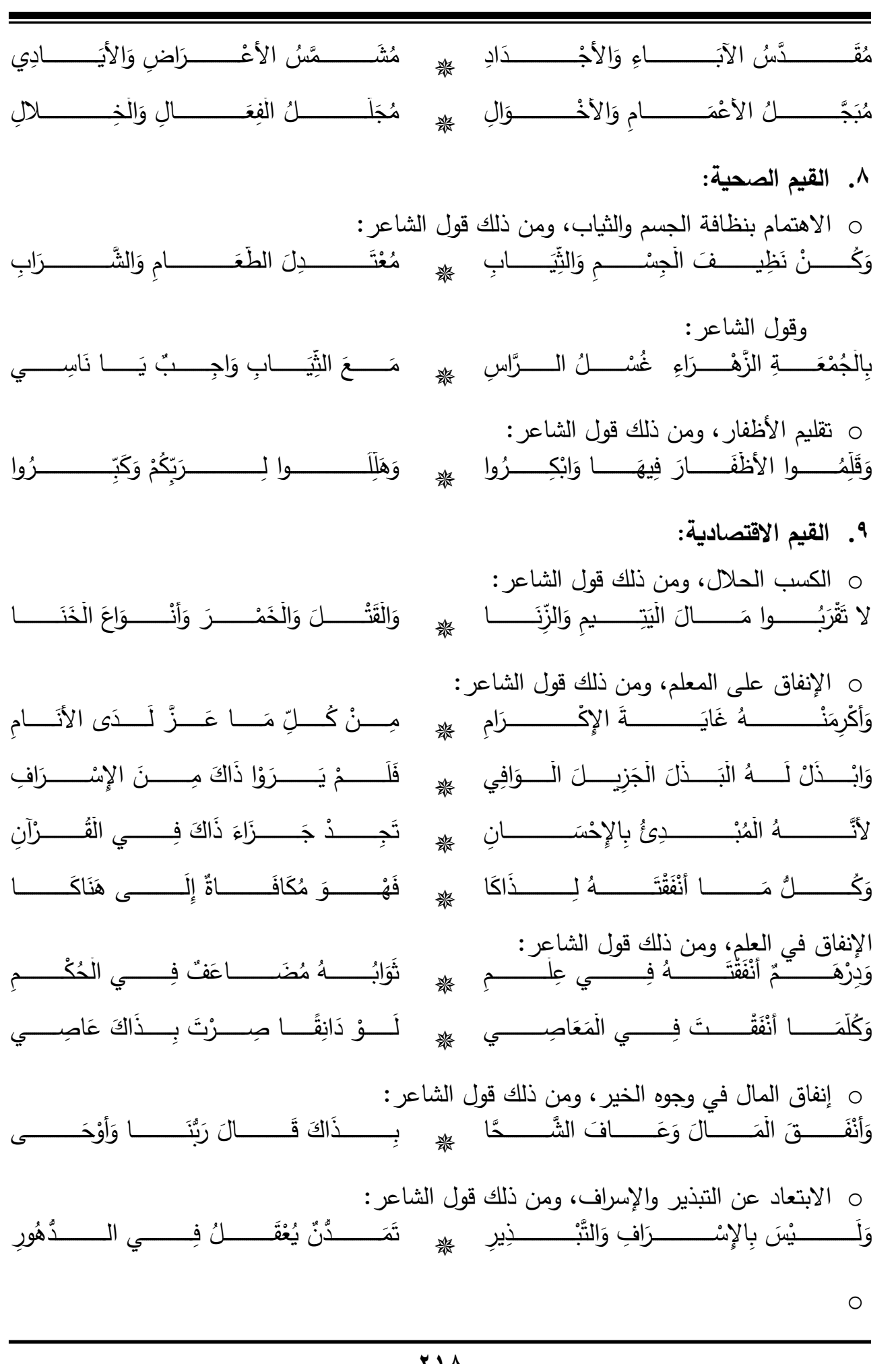


م شكر الله عز وجل على النعم، ومن ذلك قول الثاعر:

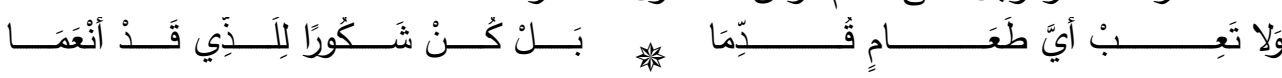

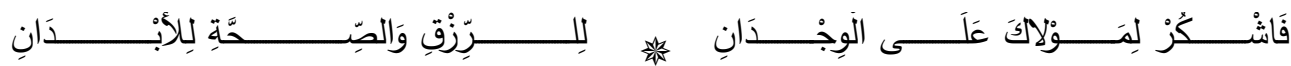

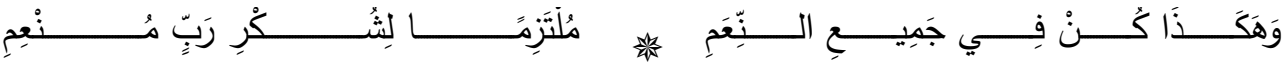

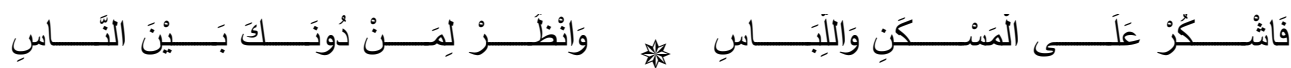
م الدعاء بالتوفيق لصالح العمل، ومن ذلك قول الثاعر :

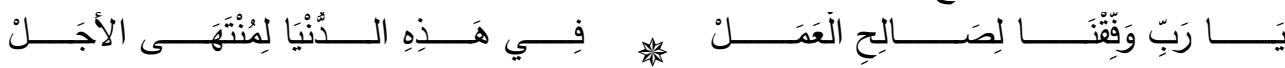

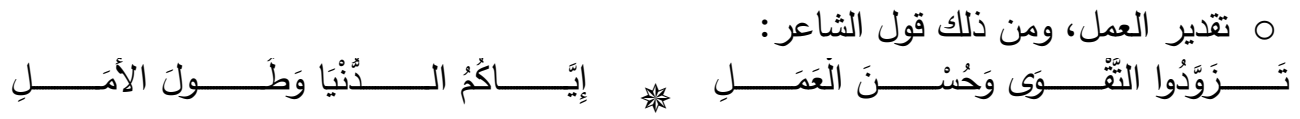

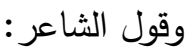

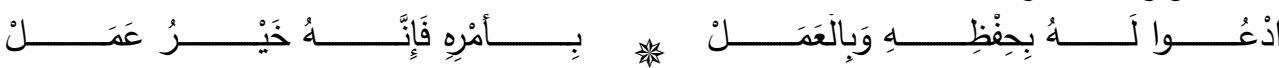
م إتقان العمل، ومن ذلك قول الثاعر :

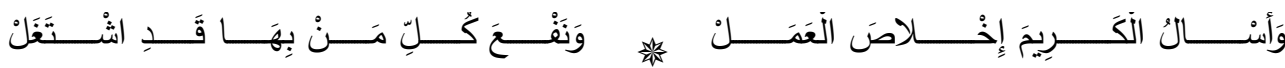
• (1القيم الترويحية: م تذوق الفنون، ومن ذلك قول الثاعر :

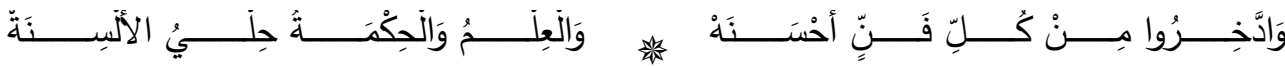
م الترويح البذني، ومن ذلك قول الثاعر :

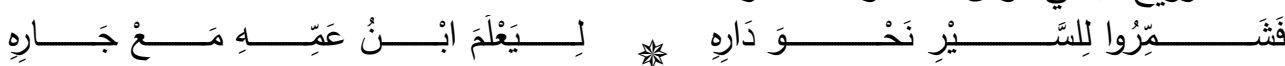

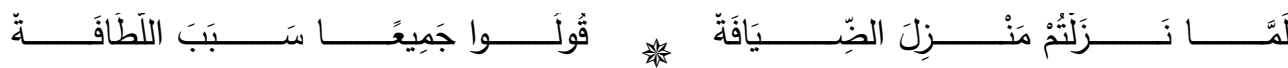
م تقسيم الوقت بين التعلم واللعب، ومن ذلك قول الثاعر :

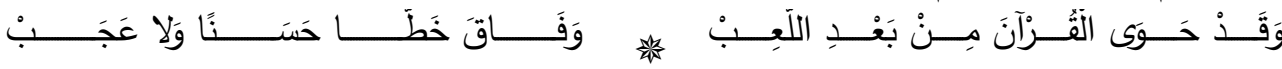

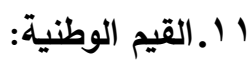
م محبة الوطن والولاء والانتماء له، ومن ذلك قول الثاعر :

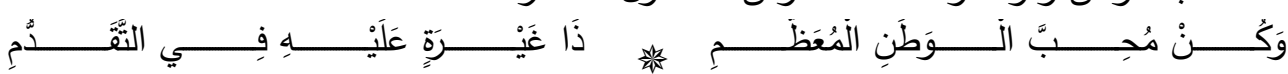




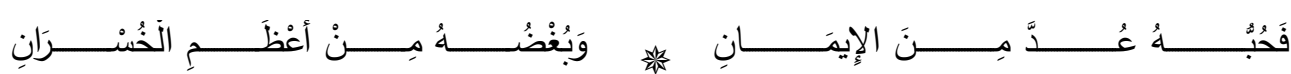

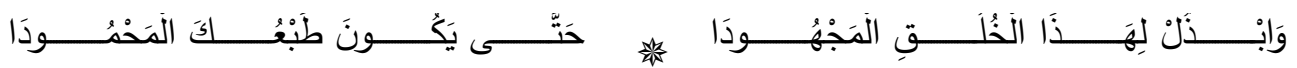
م محبة أهل الوطن على اختلافهم، ومن ذلك قول الثاعر :

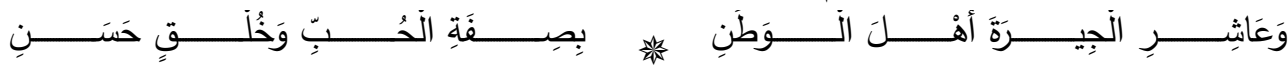
عَعَ كَالأهْلِينَ وَاعْتَبَ

وَكُ

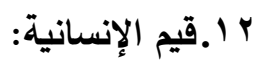
م العدل، ومن ذلك قول الثاعر :

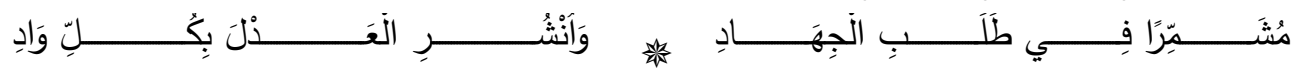

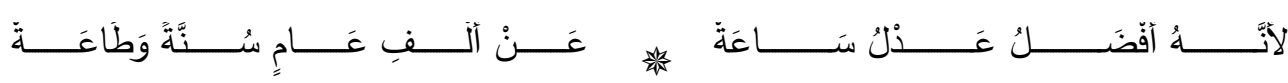
م المساواة والحرية والتسامح الديني، ومن ذلك قول الثاعر :

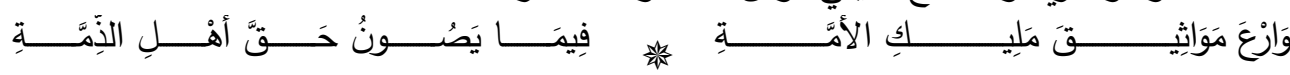

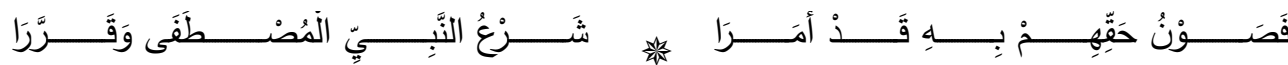

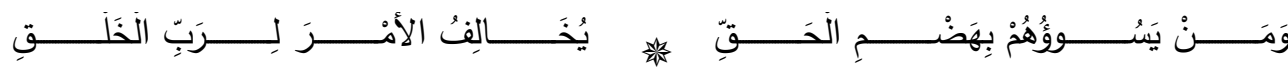
م تأدية حقوق الآخرين، ومن ذلك قول الثاعر:

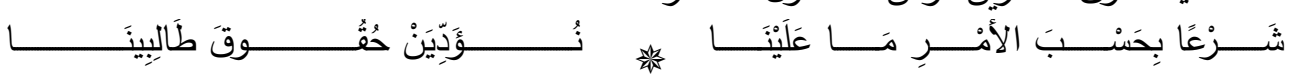

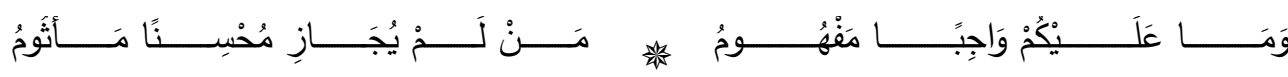

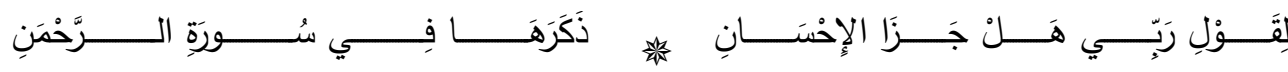
توصيات الدراسة: من خلال ما توصلت له الدراسة فإنها توصي بما يأتي:

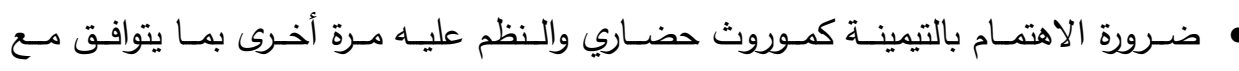

$$
\text { المستجدات التربوية الحديثة. }
$$

• جعل التيمينة حدثاً أساسياً في حفل سنوي لتخريج الطلاب والطالبات في كل مدرسة.

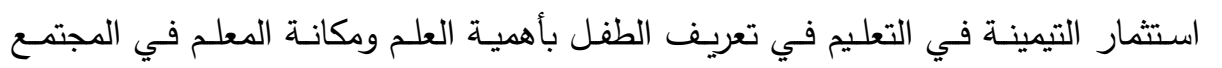

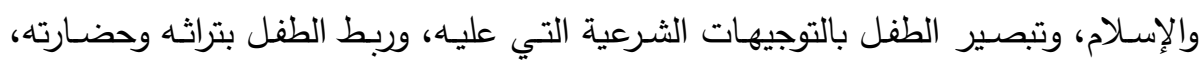
والتأكيد على المواقف الإيجابية التي على الطفل التمسك بها، ربط الطفل ببيئته وتتمية وعيه 
بها، وتبصير الأطفال بالقيم الخلقية الفاضلة التي عليهم التحلي بها، والسلوكيات الخاطئة

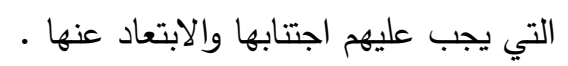
• إجراء العديد من الدراسات التقصيلية التي تبين الأهمية التاريخية والتربويـة والأدبية واللغويـة لهذا النوع من الثعر والذي لم تتطرق إليه الدراسات والمراجع التاريخية والتربويـة والأدبيـة واللغوية العربية. • استثمار التقنيات الرقمية والصوتية والمرئية في إعادة إحياء هذا الموروث الحضاري العماني بما يبرز قيمته وأهميته. المراجع الإبراشي، محمد عطية (د ت)، التربية في الإسلام، المجلس الأعلى للثؤون الإسلامية بوزارة الأوقاف، مصر.

ابن منظور، أبو الفضل جمال الدين محمد بن مكرم (ب99 (19). لسان العرب. لبنان: دار صادر. أبو العينين، علي خليل مصطفى (911). القيم الإسلامية والتربية. المدينة المنورة: مكتبة إبراهيم حلبي. أحمد، لطفي بركات (r/919). القيم وإلتربية. الرياض: دار المريخ.

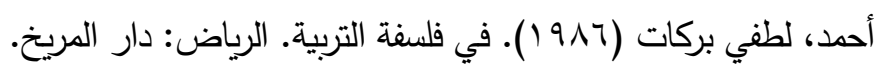

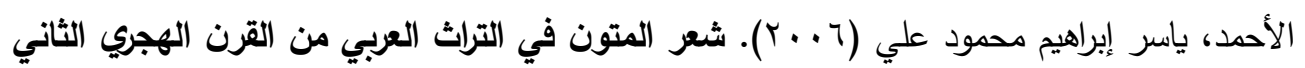

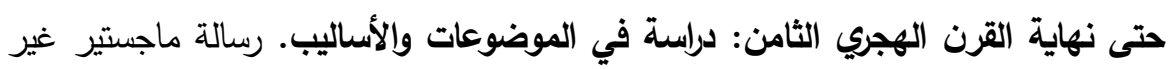
منشورة. كلية الدراسات العليا. جامعة النجاح. فلسطين.

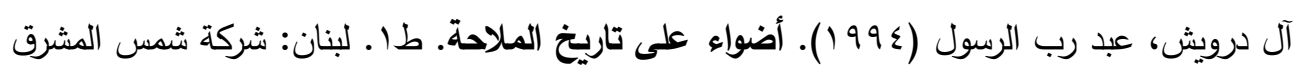
للخدمات الثقافية.

الأيوب، أيوب حسين (عـ911). من تراثنا الثعبي الكويتي: مع الأطفال في الماضي. ط ؟ . الكويت:

$$
\text { ذات السلاسل. }
$$

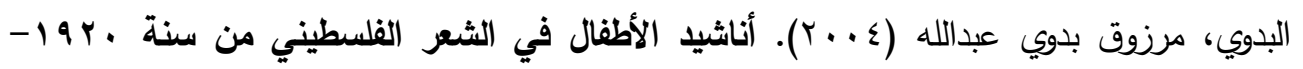
^ 9 1 ـ رسالة ماجستير غير منشورة. كلية الدراسات العليا. جامعة النجاح. فلسطين.

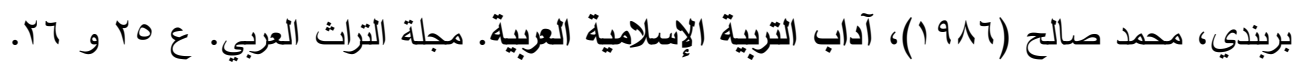

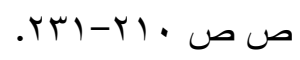


البرزنجي، جعفر بن حسن بن عبدالكريم (ت lVV الهـ) (د ت). مولد البرزنجي. صنعاء: دار ومكتبة الخير

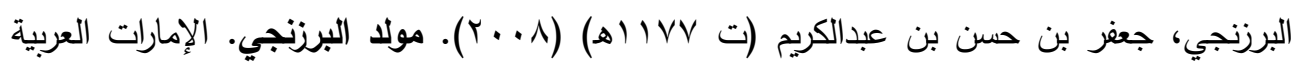
المتحدة: إصدارات الساحة الخزرجية.

البوسعيدي، سالم بن سعيد (10 • ب). الجامع في الأدب العماني. طا ـ سلطنة عمان: رؤى.

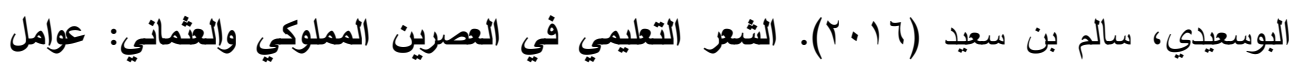

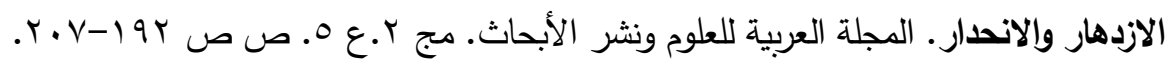
الجابري، خلفان بن ناصر (ع ا • ץ). اللوح والقلم. طا ـ. سلطنة عمان.

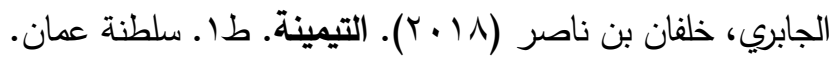

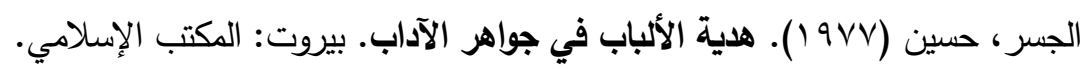

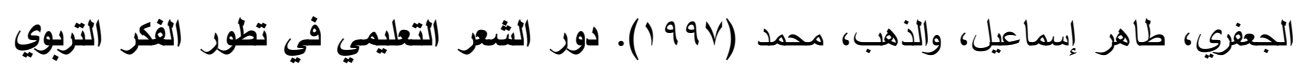

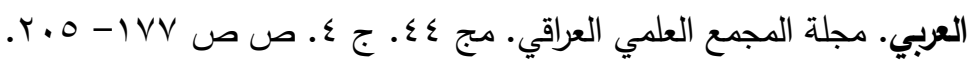

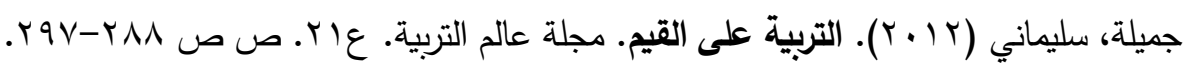

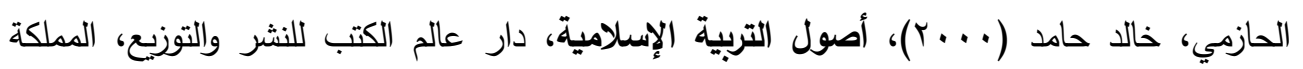
العربية السعودية.

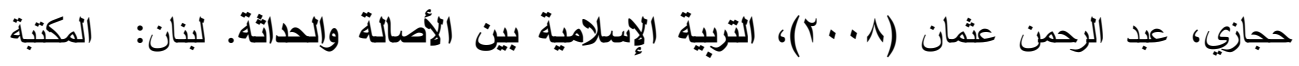
العصرية.

الحديدي، علي (911 (1). في أدب الأطفال. طء ـ مصر : مكتبة الأنجلو المصرية.

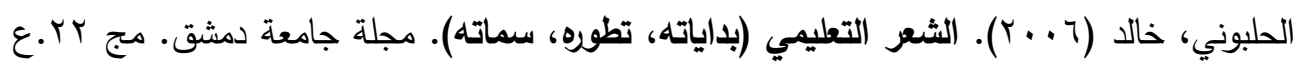
r)

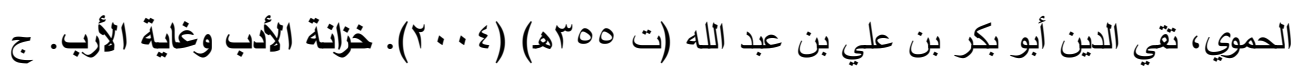

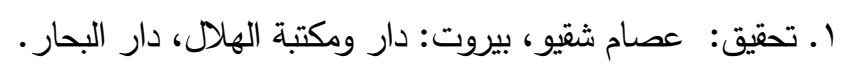

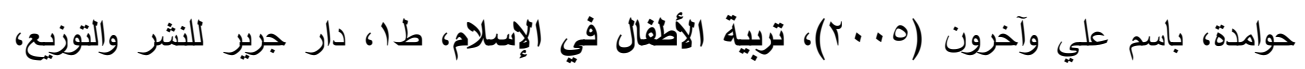
الأردن.

الخزرجي، عبدالله بن محمد بن صالح ( .99 1). الشاهد المنجي للمولد البرزنجي. سلطنة عمان.

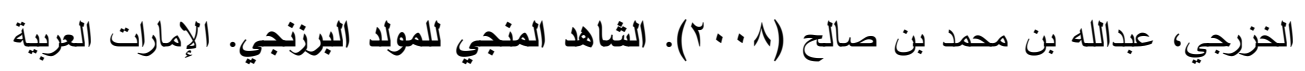
المتحدة: إصدارات الساحة الخزرجية. 
خزعلي، قاسم محمد محمود (11 + ب). القيم التربوية في ضوء الرؤية القرآنية و الحديث النبوي

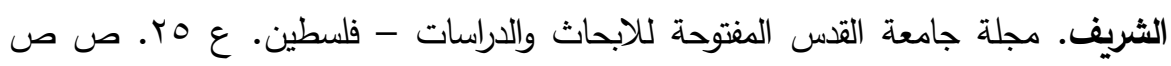

$$
\text { .1. r-00 }
$$

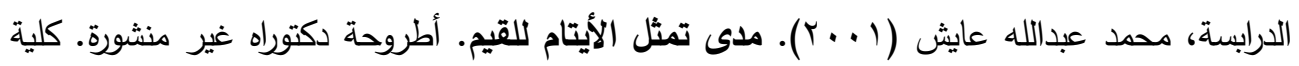

$$
\text { التربية. ابن رشد. جامعة بغداد. بغداد. }
$$

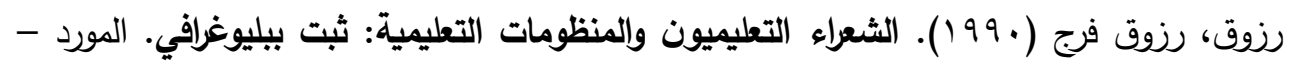

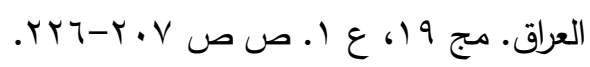

رزوق، رزوق فرج (r991). الثعراء التعليميون والمنظومات التعليمية: ثبت بيليوغرافي القسم الثاني.

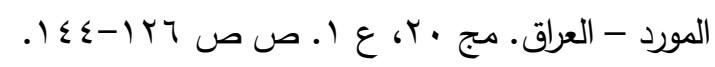

رزوق، رزوق فرج (ب99 (1). الثعراء التعليميون والمنظومات التعليمية: ثبت ببليوغرافي القسم الثالث.

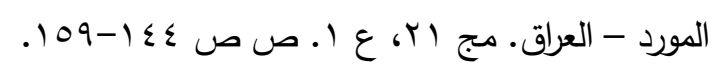

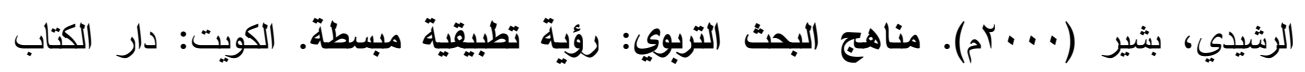
الرفاعي، عبد الرحيم ( • (1)). القيم الأخلاقية في التربية الإسلامية من واقع منهج المدرسة الابتدائية العامة. رسالة ماجستير . كلية التربية. جامعة طنطا. القاهرة.

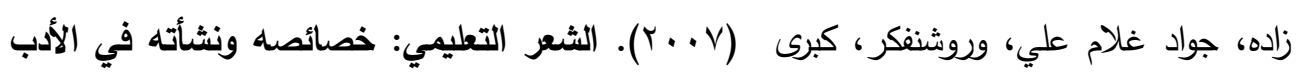

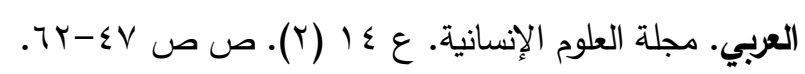

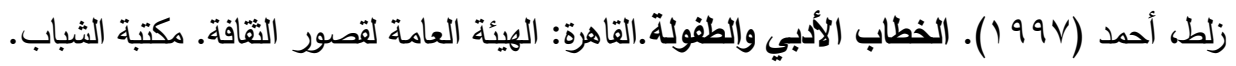

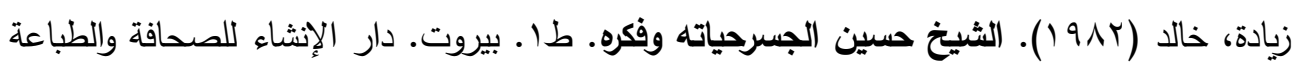

$$
\text { والنشر. }
$$

السعني، سعيد عبد الحميد محمود (YAN1 ). القيم التربوية في القصص القرآني: قصة سيدنا يوسف. رسالة ماجستير غير منشورة. جامعة عين شمس. كلية البنات. القاهرة.

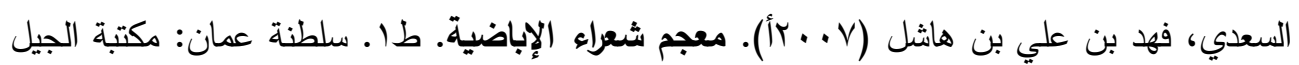

$$
\text { الواعد. }
$$

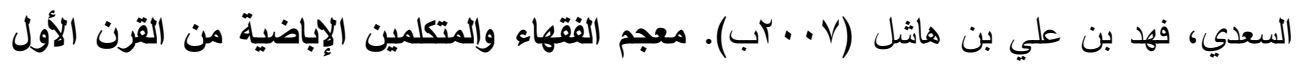
الهجري إلى بداية القرن الخامس عشر الهجري: قسم المشرق. طا ـ سلطنة عمان: مكتبة

$$
\text { الجيل الواعد. }
$$




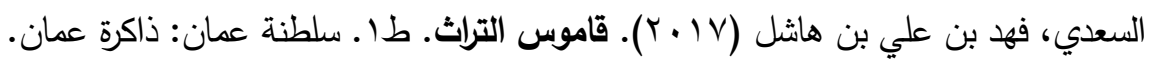

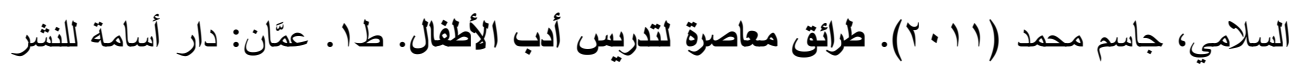
والتوزيع.

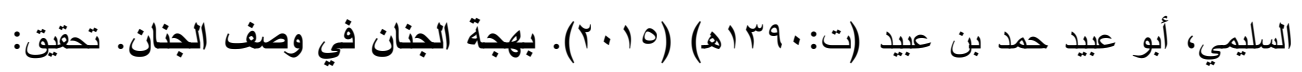
انتصار بنت محفوظ السليمي. طس. سلطنة عمان.

السويدي، وضحى علي (1997 ())، القيم الإسلامية وطرق تعلمها وتعليمها، جامعة قطر . شحاتة، حسن (ع 99 (). أدب الطفل العربي: دراسات وبحوث. ط r ـ القاهرة: الدار الدصرية اللبنانية.

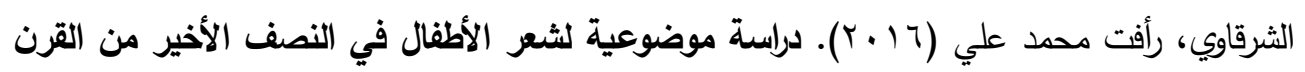
العشرين. الإسكندرية: مؤسسة حورس الدولية.

الثرياني، هلال بن محمد (911 (1). التهلولة المباركة. سلطنة عمان: مكتبة أبي الفضل بن العبلة العباس. الثعبني، مبارك بن مسلم بن مسعود (10 • ب). طيوي (يا نفس طيبي). طا ـ ـ سلطنة عمان.

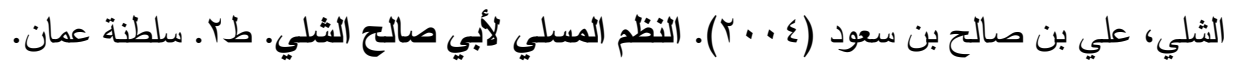
الطابور، عبدالله علي (ع . . Y). التعليم التقليدي المطوع في دولة الإمارات العربية المتحدة. الإمارات: مركز زايد للتراث والتاريخ.

الطلوحي، رعد جمال ظاهر (10 • r). البناء الموضوعي والفني في شعر عبدالرحيم البرعي. رسالة دكتوراه غير منشورة. كلية الآداب. جامعة اليرموك الأردن.

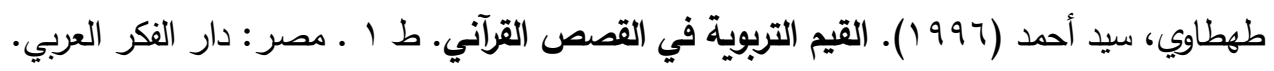
العاني، وجيهة ثابت (ع ( • ب). القيم التربوية وتصنيفاتها المعاصرة. الأردن: دار الكتاب الثقافي.

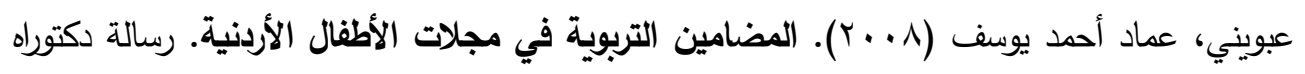
غير منشورة. كلية التربية. جامعة اليرموك. الأردن.

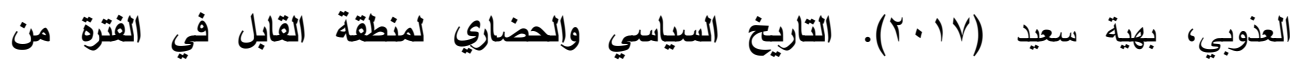

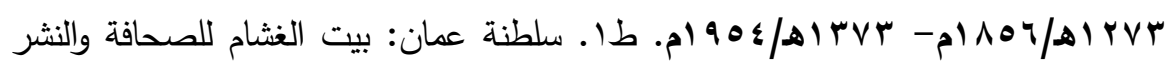
والترجمة والإعلان،والجمعية العمانية للكتاب والأدباء.

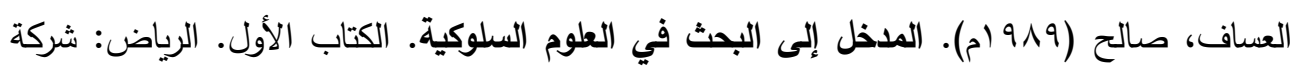

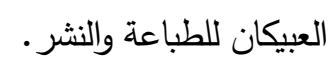

عصفور، جابر (ب991). الصورة الفنية في التراث النقدي والبلاغي عند العرب. طس. بيروت: المركز الثقافي العربي. 
عقيل، محمود عطا حسين (YV \& (هـ)، القيم المهنية. مكتب التربية العببي لدول الخليج. الرياض. عنبر، عبد الله (^ . . r). النظربة البنائية وقراءة النص الأدبي. دراسات العلوم الإنسانية والاجتماعية.

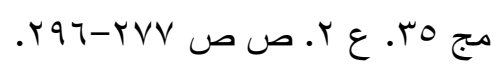

عمار ، دحمود بن إسماعيل (Y) (اه). القيم التربوية والاجتماعية في أناشيد المهر عند العرب. مجلة

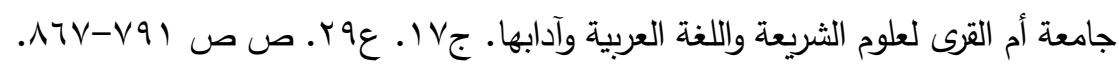

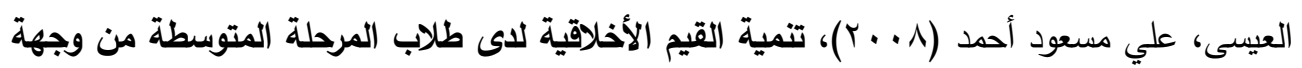

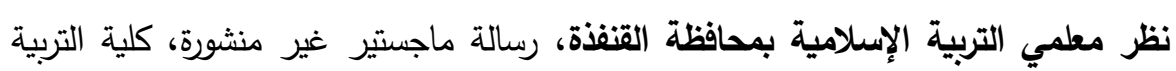

$$
\text { جامعة أم القرى بمكة المكرمة، المملكة العربية السعودية. }
$$

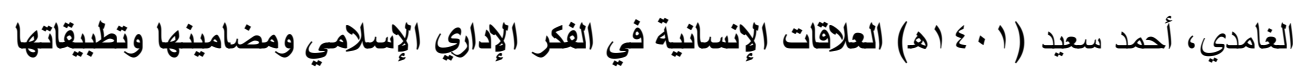
التربوية. رسالة ماجستير غير منشورة. كلية التربية. جامعة أم القرى. المملكة العربية السعودية.

غلاب، هاجر الحراثي (10 • Y). شعر النساء بالأندلس. طا ـ تونس: دار الفكر للنشر والإشهار.

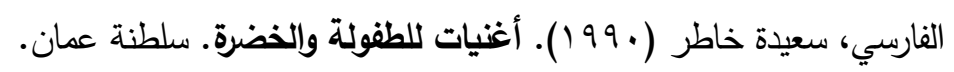

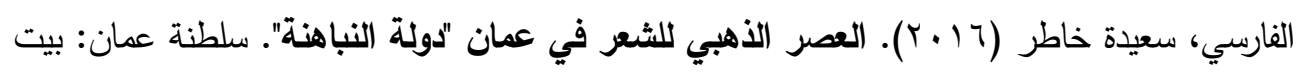

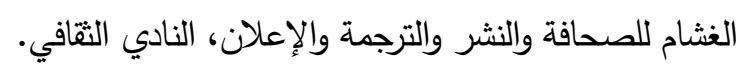

فرج، محمد سعيد (91991). البناء الاجتماعي والثخصي. الإسكندرية: دار المعرفة.

فضل، صلاح (991 (1). نظرية البنائية في النقد الأدبي. الطبعة الأولى. القاهرة: دار الثروق.

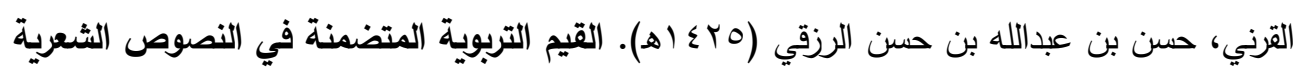
المقرة في أدب المرحلة الثانوية. رسالة جاتسير غير منشورة. كلية التربية بمكة المكرمة.

$$
\text { جامعة أم القرى. المملكة العربية السعودية. }
$$

القط، عبدالقادر (911 (1). الاتجاه الوجداني في الثعر العربي المعاصر . مصر : مكتبة الثباب.

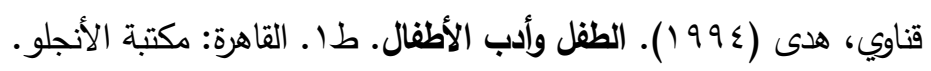

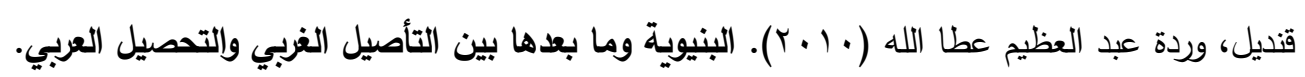
رسالة ماجستير غير منشورة. الجامعة الإنلامية. غزة.

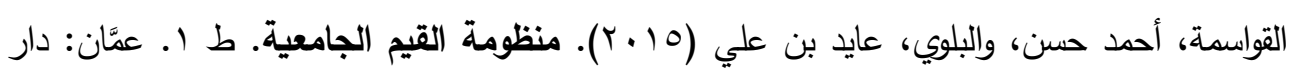
صفاء للنشر والتوزيع. كاظم، محمد إبراهيم (1971). تطورات في قيم الطلبة: دراسة تربوية تتبعية لقيم الطلاب في خمس سنوات. ط ا ـ القاهرة: مكتبة الأنجلو المصرية. 
كنعان، أحمد علي (• (99). القيم التربوية السائدة في شعر الأطفال: دراسة تحليلية ميدانية. رسالة

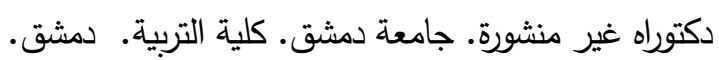

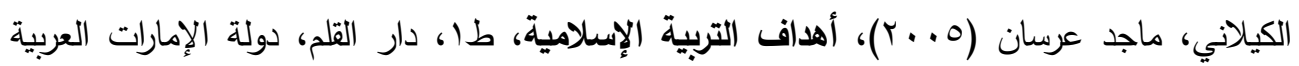
المتحدة.

المالكي، محمد بن علوي بن عباس (؟ . . ب). جلاء الأفهام شرح عقيدة العوام. جمعها اليكاى الأستاذ

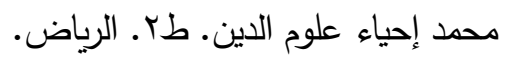

محمد، أحمد علي الحاج (9 . . ب). أغاني الأطفال الثعبية ومضمونها التربوي في مملكة البحرين.

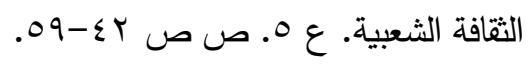

محمد، صفاء عبدالمحسن رضوان (11) ب). المضامين التربوية في شعر الأطفال في مصر في النصف الثاني من القرن العشرين. رسالة ماجستير غير منشورة. كلية التربية بسوهاج. جمهورية مصر العربية. المرزوقي، آمال حمزة (990 (1)، مضامين تربوية في سورة البقرة، مجلة دراسات تربوية، المجلد

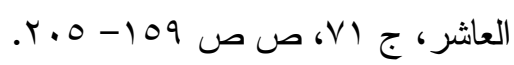

المرزوقي، أحمد السيد (ع . . r). منظومة عقيدة العوام. جمعها اليكاى الأستاذ محد إحياء علوم الدين. ط. الرياض.

مرسي، محمد منير (0 . . ب)، التربية الإسلامية أصولها وتظورها في البلاد العببية. مصر : عالم الكتب.

المعايطة، عبد العزيز (9 . . r)، المدخل إلى أصول التربية الإسلامية، طا، دار الثقافة للنشر والتوزيع، الأردن.

مكروم، عبد الودود (1997 (1). الأصول التربوية لبناء الثخصية المسلمة. القاهرة: دار الفكر العربي.

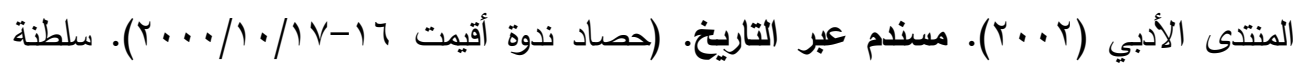
عمان.

موسوعة السلطان قابوس لأسماء العرب (1991). دليل أعلام عمان. طا. سلطنة عمان: جامعة السلطان قابوس، بيروت: مكتبة لبنان.

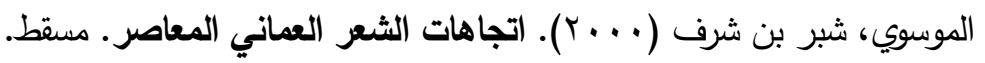

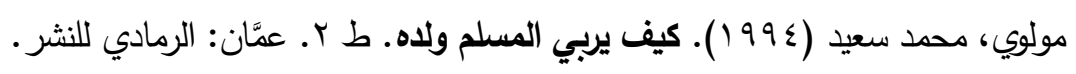


الميداني، عبد الرحمن بن حسن حَبنَّكة (1997 (). البلاغة العربية. طا. دمشق: دار القلم، بيروت: الار الثامية.

ناجي، كمال (9V7) (197. تاريخ التعليم الثعبي في قطر. مؤتمر دراسات تاريخ شرق الجزيرة العربية. اتحاد المؤرخين العرب ولجنة تدوين تاريخ قطر . الناصري، محمد علي ( •99 (1). من تراث شعب البحرين. البحرين.

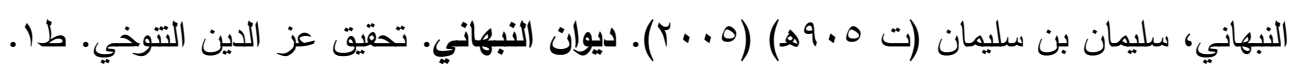
سلطنة عمان: وزارة التراث والثقافة.

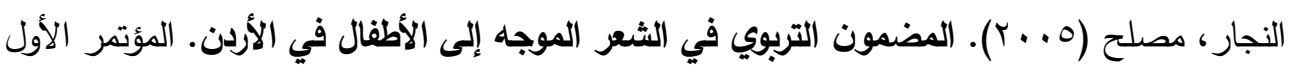
للطفول والأسرة. الجامعة الهاشمية. الأردن.

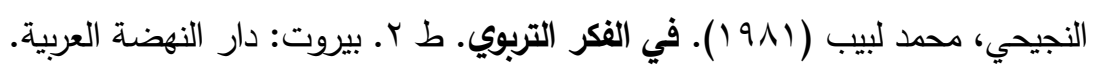

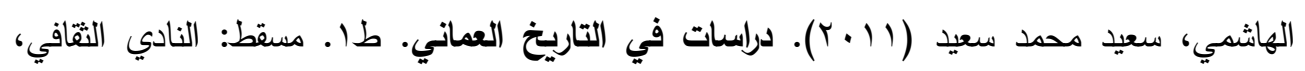
دمثق: دار الفرقد.

هلال، محمد غنيمي (999 (19). النقد الأدبي الحديث. القاهرة: دار المعارف.

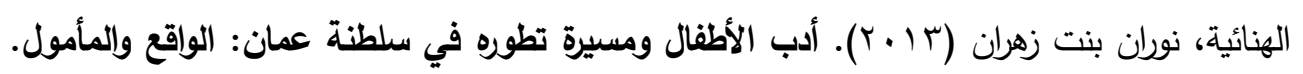
سلطنة عمان: المنتّى الأدبي.

هياجنه، هاني (10 ـ ب). صون التراث الثقافي غير المادي: الآفاق والتحديات. كتاب المأثورات الثعبية

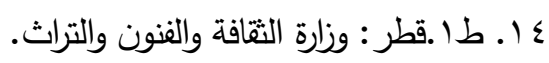

يس، السيد (1991). التحليل الاجتماعي للأدب. القاهرة: مكتبة مدبولي.

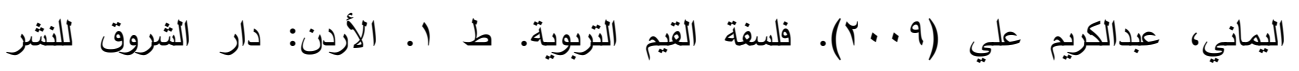
والتوزيع. 